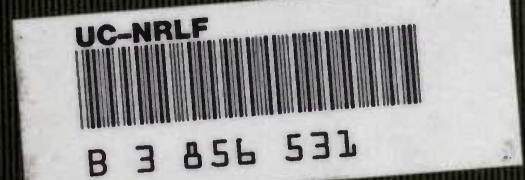




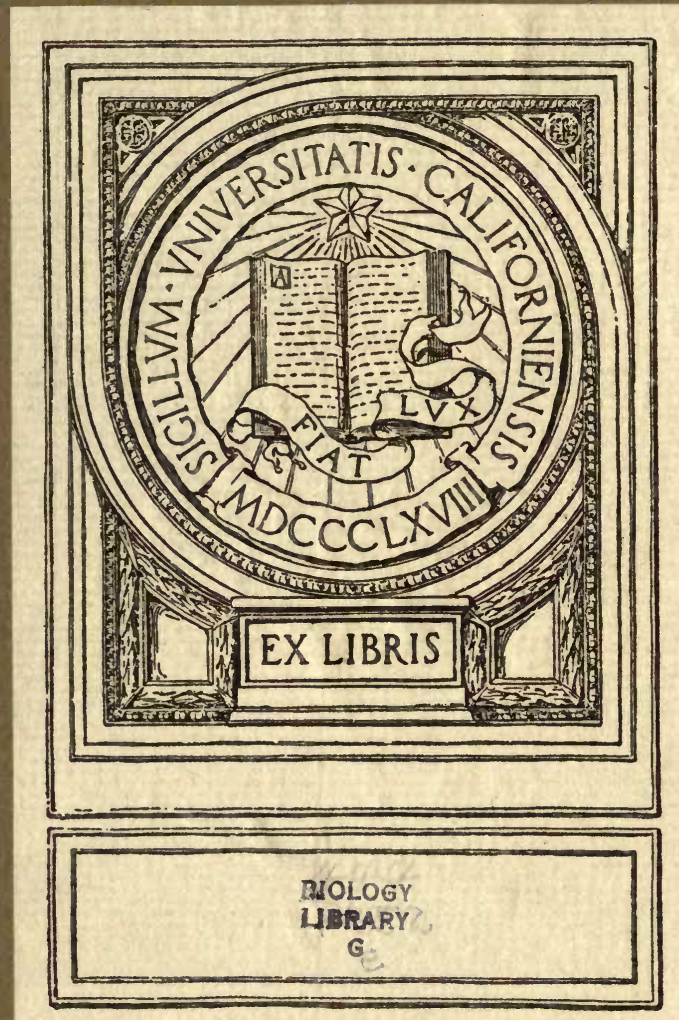


Q.6. Fif 40
2
4 ating 3. 
ELEMENTARY PLANT BIOLOGY 


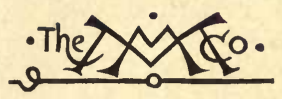

THE MACMILLAN COMPANY NEW YORK - BOSTON - CHICAGO DALLAS - SAN FRANCISCO

MACMILLAN \& CO., LiMited LONDON - BOMBAY - CALCUTTA MELBOURNE

THE MACMILLAN CO. OF CANADA, LTD. TORONTO 



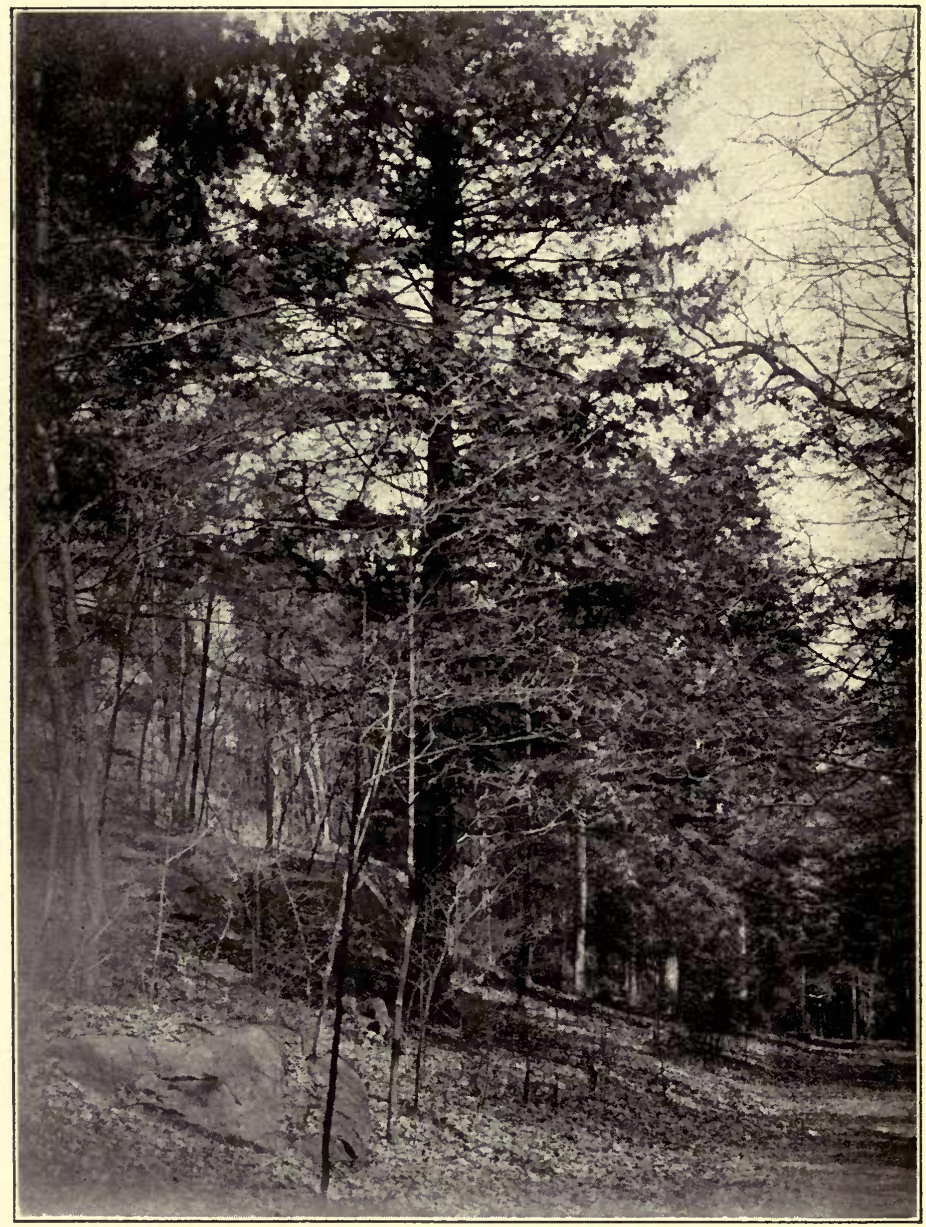

View in the Hemlock Forest, New York Botanical Garden. - (Courtesy of New York Botanical Garden.) 


\section{ELEMENTARY PLANT BIOLOGY}

BY

\section{JAMES EDWARD PEABODY, A.M.}

HEAD OF THE DEPARTMENT OF BIOLOGY, MORRIS HIGH SCHOOL BRONX, NEW YORK CITY, AUTHOR OF "'STUDIES IN PHYSIOLOGY" AND "LABORATORY EXERCISES IN ANATOMY AND PHYSIOLOGY"

AND

\section{ARTHUR ELLSWORTH HUNT, Ph.B.}

HEAD OF THE DEPARTMENT OF BIOLOGY, MANUAL TRAINING HIGH SCHOOL, BROOKLYN, NEW YORK CITY

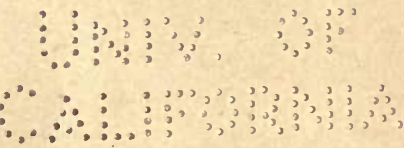

New 19ork

THE MACMILLAN COMPANY

1912 
Copyright, 1912,

BY THE MACMILLAN COMPANY.

Set up and electrotyped. Published February, Ig12.

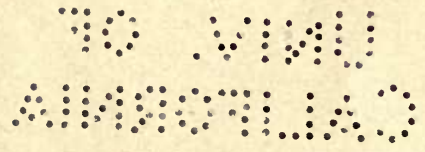


THE MEMORY OF

\section{MARTHA FREEMAN GODDARD}

WhOSE DEVOTED INSTRUCTION IN BIOLOGY IS A LAsting INFLUENCE FOR GOOD IN THE LIVES OF HUNDREDS OF BOYS AND GIRLS AND WHOSE RARE SKILL

IN LEADERSHIP IS AN INSPIRATION TO EVERY TEACHER WHO KNEW HER

THIS BOOK IS DEDICATED

BY THE AUTHORS 



\section{PREFACE}

ALL the activities of a plant, of an animal, or of man may be grouped in three classes. One class embraces the functions relating to the life of the individual organism. These functions have to do with the processes of eating, digesting, assimilating, taking in of oxygen, producing of energy, and excreting of waste matters. These may be called the nutritive functions, if the term is used in its broadest sense. To the second group of activities belong the functions that have to do with the perpetuation of the animal or plant species, and these are known as the reproductive functions. Living organisms, whether plant, animal, or human, may, in the third place, be considered in their relations to one another and especially to the general welfare of mankind. Thus we may discuss the beneficial or injurious effects, so far as man is concerned, of different kinds of insects or of various types of bacteria; we may learn of the activities of individual men or of groups of individuals which promote or retard the advance of human society; or we might, if we were to carry the study still farther, even seek to learn the ways by which the higher thoughts of mankind, as expressed in poetry, music, and religion, affect the development of the human race.

In the preparation of this text, the authors have sought to keep continually in mind these three classes of activities, and to unify the study of plant, animal, and human biology by choosing those topics for laboratory work or text description that have to do in a broad sense with one or the other of the three great groups of functions of living things to which 
we have just referred. In doing this, they are conscious that many subjects have been slighted or altogether omitted which might well be treated in a year's work in either botany, or zoölogy, or human physiology.

Again, in the treatment of a given subject, for example, stems, fishes, or circulation, special emphasis might be laid on structure, on function, or on the relation of the given topic to human life. Books both interesting and scientifically worth while could be prepared along any one of these lines, or, if time permitted, all three phases might be equally emphasized. But when we remember that less than two hundred school periods will probably be devoted by the average student to the study of biology, the necessity for adhering pretty consistently to some one plan is obvious.

In the judgment of the authors the kind of biology most worth while for the average boy or girl of fourteen years of age is not one based primarily on structure. Young students are naturally more interested in activities or functions than they are in mere form or structure. Hence, if we wish to work with, rather than " against the grain," we must put function in the foreground of our discussion. Every boy and girl knows, too, that both plants and animals as well as human beings must have food and drink, and that they grow and reproduce their kind. It is relatively much easier, therefore, to unify a course like this along physiological lines than on the basis of morphology, or of homologies of structure, many of which are far too complicated to be made clear to young students.

If properly outlined and presented, there is probably no subject in the school curriculum that can be made of more service to a growing youth than can biology. Biological problems confront him at every turn, and if he is a normal being, he will have asked himself question after question 
which an elementary knowledge of biology ought to help him to answer. Some of these questions may be the following: Whence comes the food and oxygen supply used by man? Why are food and oxygen needed in our bodies? Why are some substances beneficial to the body and others injurious? What is the cause of disease, and how is disease transmitted? And if we were to tabulate the biological questions that occur spontaneously to the average pupil in the first year in the high school, we should doubtless find that a great proportion of these questions had to do with the relation of the living world to human life. Is it not clear, therefore, if we are to outline a course in biology that will best fit the interests of the "live material," i.e. the boy or girl who is to take the course, that the central idea or factor must be man; that all the various functions considered must have some relation to human life; and that the course, to be of practical importance, must suggest to the youth better ways of carrying on his own life and of helping to improve the surroundings in which he lives?

In order, however, to treat intelligently such a function, for example, as respiration or digestion, it is of course necessary to know something of the machinery by which each of these processes is carried on, and so there must be at least a minimum consideration of the structure of plants, animals, and the human body. In every case, however, the authors have called attention only to those details which seem to be absolutely essential for an interpretation of the function under consideration. Whenever names in common use are sufficiently accurate for descriptions, these are chosen in preference to scientific terms. Frequently the latter are necessarily used, and so, whenever their meaning is made clearer by referring to their derivation from Latin or Greek, these derivations are indicated in parentheses. 
The sections in coarse type contain the material that seems to the authors most essential for any clear understanding of the subject as a whole, while in fine type we have put additional laboratory work and text description which we believe to have an important bearing on the various topics discussed. If both coarse and fine print on animal, or plant, or human biology are used, sufficient material for a half-year course in either elementary botany, zoölogy, or human physiology will be provided.

In the judgment of the authors, plant biology should always be considered first and human biology last in the course for the following reasons: (1) Plants lend themselves far more readily to close observation and especially to experiments than do animals, and so fundamental processes which apply to all living things can be demonstrated scientifically from plant material. (2) Plants are the final source of all the food supply of animals and man, and if the composition and manufacture of the nutrients are taught early in the course, a solid foundation is laid for all subsequent study of nutrition in animals and man. (3) The purpose of the animal study is largely that of showing the adaptations of animal structure to functions and the relations of the animals studied to human welfare. (4) And finally, if human biology comes last in the course, it may be presented in such a way as to review, sum up, and give real significance to many of the facts learned earlier in the course. In fact, as the work proceeds, comparisons will constantly be made between plants, animals, and man to show that the essential differences in the three kinds of organisms consist not in the differences in the functions which they carry on, but in the organs by which the functions are performed.

So far as the order of individual topics under plant, animal, and human biology is concerned, the instructor should 
plan the sequence that best fits the season. In fact, the last use that a good teacher will make of any laboratory manual or text-book is that of following it slavishly. It is the hope of the authors, however, that the laboratory guides and the text descriptions which follow may be sufficiently suggestive to help some teachers to work out improved methods in biological instruction. In Appendix II will be found a suggested order of topics which the authors have found satisfactory.

Living organisms are to a large extent to be regarded as chemical engines so constructed as to liberate different kinds of energy. No one, of course, knows in any ultimate sense how even the simplest functions are performed by the simplest animals or plants. But it is utterly useless to attempt to teach biological functions without first presenting some of the elementary principles involved in physical and chemical phenomena. For this reason the first chapter in Plant Biology is devoted to the study of the Composition of Lifeless and Living Things. In Chapter III is a brief discussion of the structure of a common plant, and since cells are fundamentally alike in structure and functions in all living organisms, emphasis is laid early in the course on the essential characteristics of these cellular elements in plants. Another topic which necessarily recurs throughout plant, animal, and human biology is the principle of osmosis and its applications. The authors have inserted experiments which in their experience have helped to fix in mind this important principle and which demonstrate the necessity of digestion in plants and animals.

After this brief consideration of the fundamentals of plant composition, structure, and processes, Chapters V, VI, and VII are devoted to the study of the adaptations of plants for performing nutritive and reproductive functions. In 
Chapter VIII are grouped experiments and descriptions the aim of which is to show various ways in which plants are propagated. This treatment presents only the briefest statement of underlying principles, since any extended discussion of this topic belongs to a course in agriculture.

In Chapters IX (Plants in their Relation to Human Welfare) and X (Plant Classification) the method of presentation is strikingly different from that adopted in the rest of the book, particularly so in the treatment of the spore-bearing plants. The authors believe that every pupil should be taught something of these simpler forms (especially bacteria), and that he should get as many of these facts as possible by observation. But to expect much laboratory work from young students on difficult microscopic forms like many of these cryptogams, is, we are confident, quite out of the question. We have, therefore, frankly abandoned the inductive method of study and have suggested that the laboratory work be largely in the nature of demonstrations. It is, of course, understood that if these forms are studied, the drawings and descriptions will be prepared from material in the hands of the student.

In our judgment there are few if any biological topics which are more important in their practical bearings than is that of bacteria. As commonly studied the disease-producing effects of these organisms are emphasized so much that boys and girls do not appreciate that all the work of the higher plants depends ultimately upon the activity of these low forms of fungi. In order to bring out this aspect of the work of bacteria and for other obvious reasons the structure, physiology, and economic benefit of these organisms are considered in the chapter on the relation of plants to human welfare, while their pathogenic effects are reserved for discussion in human biology. 
In the preparation of this book the authors have received a great many suggestions from the teachers in their own departments and those of other schools. Our thanks are due to Miss M. Helen Smith of the Manual Training High School, Brooklyn, N.Y. for several laboratory outlines which formed the basis of corresponding studies in the following pages. The authors have been especially fortunate in securing the constructive criticism of Dr. C. Stuart Gager, Director of the Brooklyn Botanic Garden of the Brooklyn Institute of Arts and Sciences. He has carefully read all of the manuscript and the page proofs.

We are indebted to Dr. H. J. Webber, Professor E. O. Fippin, and others at Cornell University, for valuable material and illustrations for the chapter on Plant Propagation. We wish, also, to express our hearty appreciation of the generous permission of Henry Holt \& Co. to use some of the material published in Peabody's "Laboratory Exercises in Anatomy and Physiology." We are fortunate, too, in securing from the New York Botanical Garden photographs for the frontispiece, and for several fine cuts in the text, and from Professor E. M. East of Harvard University the cut for Fig. 52. Miss Mabelle Baker, Miss Clara Lang, Miss Margaret Cutler, and Miss Grace Gamble, students in our first-year classes, have kindly prepared for us the figures on which their severàl names appear.

Cost prices for the items on the list of laboratory apparatus and equipment were kindly furnished us by Bausch \& Lumb, Kny-Scheerer, and O. T. Louis; from these prices the estimates on pp. 173 to 177 were prepared.

J. E. P.

A. E. H.

January 31, 1912. 



\section{TABLE OF CONTENTS}

Preface

CHAPTER

I. General Introduction. • • • • • • 1

II. Composition of Lifeless and Living Things . - 5

I. Elements, Compounds, and Oxidation • . 5

II. Definitions • • • . • • • . 12

III. A Study of the Food Substances _ . . 13

IV. Manufacture of the Food Substances by Plants . 22

III. The General Structure of Plants a $\quad$ - 26

IV. Osmosis and Digestion • • • • • • • 32

V. Adaptations of the Nutritive Organs of Plants 39

I. The Structure and Adaptations of Roots . . 39

II. The Structure and Adaptations of Stems . . 45

III. The Structure and Adaptations of Leaves . - 52

Vi. Respiration and the Production of Energy in

Plants . . . . . . . . . 64

ViI. Reproduction in Plants . • . • . $\quad$. 70

I. The Structure and Adaptations of Flowers $\quad$ 70

II. The Structure and Adaptations of Fruits . $\quad 89$

ViII. Plant Propagation . . . . . . 97

I. Seeds and their Development into Plants . $\quad$ - 97

II. (Optional.) Other Methods of Plant Propagation . . . . . . . 105

III. Conditions Essential for the Growth of Plants . 108

IV. (Optional.) The Struggle for Existence and its Effects . . . . . . . . 114

V. (Optional.) The Improvement of Plants by Man 119 XV 
IX. P'lants in their Relation to Human Welfare • 126

I. Some of the Uses of Plants to Man a $\quad$. 126

II. The Uses of Forests and Forest Conservation 132

III. Fungi and their Relation to Human Welfare 139

X. Plant Classification . • • • • • . 154

I. (Optional.) Common Methods of Classification . 154

II. (Optional.) Scientific Methods of Classification . 158

Appendix

I. Laboratory Equipment $\quad$ • $\quad$ • $\quad$ • 171

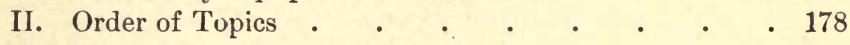

III. Biology Note-books • • • • • • 181

IV. Review Topics in Plant Biology . . . . 188

V. List of Suggested Books of Reference in Biology 197 
ELEMENTARY PLANT BIOLOGY 



\section{PLANT BIOLOGY}

\section{CHAPTER I}

\section{GENERAL INTRODUCTION}

1. Lifeless Things and Living Things. - As we look about us, we find that the world in which we live is wholly composed of two classes of things, which we commonly speak of as living things and lifeless things. Soil, air, and water, for example, we know to be lifeless. Water is probably the simplest of these three so far as its composition is concerned. Soil, on the other hand, is very complex in composition, being formed of nearly all the substances known to the scientist. Enveloping the earth is a mixture of gases called the atmosphere which extends outward in every direction for a distance of about fifty miles. Everrybody knows, too, that over the surface of the earth, in the water, and even in the air are countless numbers of living things which we designate as either plants or animals.

One might think that it would be an easy matter to set down the characteristics by which living things are distinguished from those that are lifeless. And such is the case when we compare a rock in a field with a horse that is feeding beside it. Unlike the animal, the lifeless rock is unable to move itself, it neither eats nor breathes, and it gives no evidence of feeling or of will power.

But suppose we select for comparison a railroad locomotive and a horse. Both move; both need a plentiful supply of air ; 
both develop heat and power to do work; and both give off certain waste matters. The horse, we may say, requires food, but so does the engine; for coal and water are as necessary for the development of heat and power in the engine, as food and water are for a similar purpose in the horse.

When we try to state characteristics that will distinguish all plants from all lifeless objects, we find the task still more difficult; for most plants do not move about from place to place, it is difficult to realize that they give off heat, and they do not give evidence that they have conscious feelings as do the common animals. In spite, however, of these similarities, we are usually able to distinguish living from lifeless objects at least by the three following characteristics.

2. Growth of Living Things. - In the first place living things use some of the food they eat for growth. No one ever heard of an engine or other lifeless object beginning as a small machine, and then slowly growing larger until it comes to have many times its former weight. ${ }^{1}$ Yet this is what happens to all plants and all animals. The average child, for instance, at birth weighs seven to eight pounds ; while a man's weight is over twenty times as great. And if we try to compare the weight of an oak tree with that of an acorn from which it started, the amount of increase we find to be enormous.

3. Repair of Living Things. - In the second place, parts of a locomotive or of any other lifeless machine by continual use become worn or broken, and the engine must be sent to the machine-shop for repairs. Our bodies, too, are being constantly worn away; for every time we make a motion of

${ }^{1}$ While it is true that icicles and other crystals apparently grow, this kind of growth is brought about wholly by the addition of material to the outer surface. 
any sort, some of our living muscle is used up; every time we think or exert our will power, some of the living brain substance is probably changed into dead waste material. But in contrast to lifeless machines, our bodies are self-repairing. The food we eat not only goes to increase the size of the body; it also furnishes material to make good the wear and tear of everyday life. This power of self-repair is likewise present in all animals and in plants as well.

4. Reproduction of Living Things. - A third characteristic that distinguishes living things from those that are lifeless is the fact that they produce seeds (in the case of plants) or eggs (in the case of animals), which in turn come to form plants or animals like those by which these seeds or eggs were produced. No lifeless object can do this. We shall find in our laboratory study that, while there are a great many different methods of producing these new organisms, still in their essential features these various methods of reproduction are much the same from the lowest plants to the highest animals.

5. Summary. - In brief, then, we may say that all living things have the power of growth from within, of self-repair, and of the reproduction of their kind; but that so far as we know lifeless objects possess none of these powers.

6. Science and its Subdivisions. - Ever since the dawn of history we find that mankind has been seeking to learn the secrets of living and lifeless matter. During the past century our knowledge has increased so rapidly that many sciences have been completely rewritten. The discoveries, for example, of the characteristics of radium and of X-rays have revolutionized much of what was formerly believed as to the properties of lifeless matter. In the same way our increased knowledge regarding germs and other microscopic plants and 
animals has made possible the scientific treatment of disease, and what is more important, the prevention of disease. As our knowledge of the living and lifeless world has increased, it has become necessary to divide this knowledge into a great many different branches, some of which are physics, chemistry, geology (a study of the earth), mathematics, psychology (a study of mind), and biology.

7. Biology (from Greek, $b i^{\prime} o s=$ life $+l o^{\prime} g o s=$ discourse) is the general name given to the study of all living things. Hence, this science treats of both animals and plants. If we confine our study to the structure and activities of plants alone, we call this part of the science plant biology, or botany. Animal biology, or zoölogy, on the other hand, treats of animals. So-called human physiology (better known as human biology) discusses man, the highest type of the animal kingdom; hence, it is a branch of the science of zoölogy, which in turn is one of the subdivisions of the study of biology. 


\section{CHAPTER II}

\section{COMPOSITION OF LIFELESS AND LIVING THINGS}

8. Introduction. - For a great many years scientists have been studying plants and animals, and from this study they have learned that the bodies of all living organisms, including human beings, are made from substances found in the water, soil, and air, and that when plants and animals cease to live, their bodies are changed into the chemical substances of which soil, air, and water are composed. We are now to learn by experiments the characteristics of some of these materials found in lifeless things, and some of the combinations of these materials in plants and animals.

\section{Elements, Compounds, and Oxidation}

Materials: Splinters of wood and pieces of carbon; starch, sugar, egg, meat; potassium chlorate, oxid of manganese, pieces of marble, zine, hydrochloric acid, lime water (see below); elements for demonstration (e.g. phosphorus, sulphur, iron, magnesium); compounds for demonstration (e.g. magnesium sulphate, sodium nitrate, potassium nitrate, calcium phosphate, calcium carbonate); test tubes, thistle tube, apparatus stand, tray for collecting gases, delivery tube, cylindrical graduate or glass jar. (All of the materials named above will be found in the chemical or physical laboratory of almost every high school.)

Preparation of lime water: Put into a large bottle a good handful of lime (freshly slaked in water, if possible; air-slaked lime may be used, however). Fill the bottle with water, shake the mixture, and 
allow it to stand until needed. Then pour some of the liquid through a funnel in which is a filter paper. Collect the filtered lime water in a bottle, and keep it stoppered. As soon as it becomes cloudy, throw it away and obtain some more clear liquid by filtration as directed above. The large bottle can be kept indefinitely as a stock solution if it is kept filled with water.

9. Carbon (symbol, C). - Laboratory Study No. 1. Suggested as home work.

1. Prepare some charcoal by lighting a long splinter of wood or a match and then blowing out the flame. (Prepared charcoal may be used.) Charcoal is nearly pure carbon.

a. Tell what you have done.

b. Is carbon (charcoal) a solid, a liquid, or a gas? What is its color?

c. Of what substance does this experiment prove that wood is partly composed?

2. Hold the tip of the carbon (charcoal) in a hot flame.

$a$. State what was done.

b. Does any of the carbon disappear?

c. Will carbon burn? How do you know?

3. State three characteristics of carbon (charcoal) that you have learned from these experiments.

4. Hold your hand over the glowing charcoal with your eyes closed. How can you still tell that the carbon is burning?

\section{Oxygen (symbol, O). - Laboratory Study No. 2.} Demonstration.

Preparation of oxygen: Thoroughly mix a teaspoonful of potassium chlorate with about one-fourth as much black oxid of manganese. Put the mixture in a large test tube. Close the mouth of the test tube with a stopper through which passes a delivery tube, the other end of which runs beneath the surface of water in a tray. Support the test tube in a slanting position on an apparatus stand, and heat the mixture gently with a gas or an alcohol flame, until 
the oxygen begins to be given off. Fill three or four bottles with water, cover each with a piece of glass or cardboard, and invert the first one over the mouth of the delivery tube, removing the cover when the mouth is under water. Continue to heat the mixture until the bottle is full of oxygen, then cover it under water with the glass plate or cardboard, and stand it right side up on the table. In the same way fill as many jars as are needed for the experiments with oxygen. (Fig. 1.)
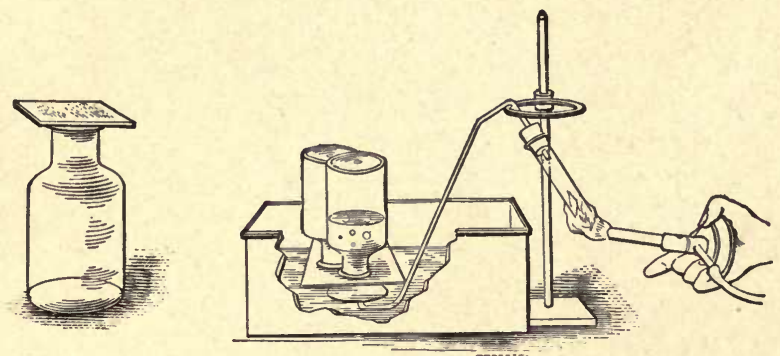

Fig. 1.-Preparation of oxygen.

Prepare several bottles of oxygen as directed and allow them to stand until all fumes have settled, before answering the following questions.

1. Examine a bottle of oxygen.

a. State what you have done.

$b$. Do you find oxygen to be a solid, a liquid, or a gas?

c. State whether or not oxygen has color.

2. Heat some charcoal (carbon) till it glows and thrust it into a bottle of oxygen.

a. Tell what was done and describe what happens.

$b$. Does carbon burn better in air (which is a mixture of oxygen and other gases) or in pure oxygen?

3. State the three characteristics of oxygen which you have learned.

11. Carbon dioxid (formula, $\mathrm{CO}_{2}$ ). - Laboratory Study No. 3. Demonstration. 
Preparation of carbon dioxid: Into a flask put some pieces of marble, and insert a stopper through which passes a thistle

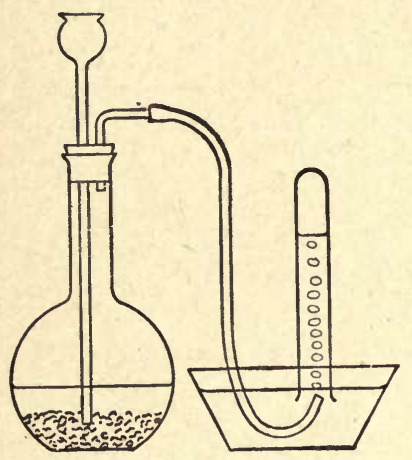

Fig. 2. - Preparation of carbon dioxid or of hydrogen. tube and a delivery tube like that used in the preparation of oxygen. Pour into the thistle tube diluted hydrochloric acid until the lower end of this tube is covered. Collect a bottle of carbon dioxid in the same way that oxygen is collected, keeping the mouth of the bottle closed with a glass plate or cardboard. (Fig. 2.) Prepare a bottle of carbon dioxid as directed, and allow it to stand till all fumes have disappeared, before answering the following questions.

1. Examine a bottle of carbon dioxid and state whether it is a solid, a liquid, or a gas. Compare this gas and oxygen as to color.

2. Light a splinter of wood and thrust it into the bottle of carbon dioxid.

a. Tell what was done and describe the effect of the carbon dioxid upon the burning splinter.

$b$. How was the burning splinter or carbon affected by oxygen?

3. Generate some carbon dioxid as suggested above and pass it through the delivery tube into a test tube of clear lime water. Tell what was done and describe the effect of carbon dioxid on lime water. (Carbon dioxid is the only gas that affects lime water in this way; hence the latter is a reliable test for carbon dioxid.)

4. State the four characteristics of carbon dioxid which you have learned from these experiments.

5. Place in a bottle of pure oxygen a piece of glowing carbon, and allow it to burn as long as it will. When the carbon ceases to burn, quickly remove 
it, and pour in some clear lime water, cork the bottle, and shake.

a. Tell what was done and describe the change that takes place in the lime water.

$b$. What substance is evidently formed when carbon burns in oxygen?

6. When carbon is burned in oxygen, the two unite to form a new substance entirely different from either carbon or oxygen. This new substance is called carbon dioxid, because it is composed of one part of carbon and two of oxgyen.

a. Describe the composition of carbon dioxid:

$b$. State the method by which carbon dioxid was produced in this experiment.

7. (Optional.) By means of a glass tube blow the breath from the lungs into a test tube of lime water.

$a$. What change do you notice in the lime water?

$b$. What do you therefore conclude to be contained in the breath from the lungs?

12. Hydrogen (symbol, $\mathrm{H}$ ) and water (formula, $\mathrm{H}_{2} \mathrm{O}$ ). Laboratory Study No. 4. Demonstration.

Preparation of hydrogen (see Caution below): Into a flask put some pieces of zinc. (See Fig. 2.) Insert a stopper with two holes. Through one of the holes pass the lower end of a thistle tube until it nearly touches the bottom of the test tube, and through the other run a short piece of glass tubing. To the upper end of the latter attach by means of a piece of rubber tubing a delivery tube that will reach beneath the surface of a tray of water such as that used in collecting oxygen and in the preparation of carbon dioxid. Pour through the thistle tube enough diluted hydrochloric acid to cover the lower end of the thistle tube. (If hydrogen does not come off rapidly enough, put into the flask a bit of copper sulphate.) After the hydrogen has been given off for several minutes, collect a bottle over water in the same manner as in the oxygen experiment. Remove the bottle, holding it upside down, and place it on the desk in this position. Allow the bottle to stand till fumes disappear. 
Caution: If in 3 below an explosion occurs, collect another bottle of hydrogen before answering the questions, for an explosion indicates that oxygen is mixed with the hydrogen, and such a mixture is dangerous to experiment with.

1. Examine a bottle of hydrogen, and state whether hydrogen is a solid, a liquid, or a gas. Compare its color with that of oxygen and carbon dioxid.

2. Thrust a lighted stick up into the mouth of an inverted bottle of hydrogen. (This experiment will be more satisfactory if the room is darkened.)

$a$. State what was done and tell how the hydrogen affected the burning stick.

$b$. How does the burning stick affect the hydrogen?

c. What is one difference between oxygen and hydrogen?

$d$. What is one difference between hydrogen and carbon dioxid?

3. If hydrogen is not being given off from the delivery tube in sufficient quantity, pour into the thistle tube some hydrochloric acid. Detach the delivery tube from the rubber tube of the hydrogen apparatus and insert in its place a piece of glass tubing, the upper end of which is drawn out to a small diameter. Collect some of the gas in a test tube by displacement of air and light it. When it burns with only a slight puff, apply a lighted match to the hydrogen escaping from the drawn-out tube.

Hold over the flame a bottle which is clean and dry.

$a$. Describe the preparation of this experiment.

$b$. What do you find on the inside of the glass?

c. What, therefore, is formed when hydrogen burns?

4. When hydrogen burns, it unites with the oxygen of the air and forms oxid of hydrogen, more commonly known as water (formula, $\mathrm{H}_{2} \mathrm{O}$ ).

a. In what respect does hydrogen differ from oxid of hydrogen (water) in its most common form?

$b$. State how oxid of hydrogen was formed.

c. In what respects is the method of producing oxid of hydrogen (water) the same as that of producing oxide of carbon (carbon dioxid)? (See 11, 5 above.)

5. Name five characteristics of hydrogen. 
13. Nitrogen (symbol, $\mathbf{N}$ ) and the composition of the air. - Laboratory Study No. 5: Demonstration.

Fasten a candle to a piece of cardboard and float the latter on a tray of lime water. Light the candle, and cover the flame with an inverted wide-mouthed bottle, bringing the latter slowly down until the edge rests on the bottom of the tray. Allow the candle to burn as long as it will. Then turn the bottle right side up, covering the mouth with the cardboard, keeping inside the bottle the lime water that has risen to take the place of the oxygen. Shake the contents of the bottle, to make the lime water absorb the carbon dioxid, and allow it to stand till the upper part of the jar is clear. Keep the bottle covered to prevent the mixing of air with the nitrogen.

1. Examine a bottle of nitrogen. Is it a solid, a liquid, or a gas? What is its color?

2. Thrust a burning splinter of wood into the nitrogen.

$a$. Tell what was done. Does the wood continue to burn?

$b$. Does the nitrogen burn?

c. In what respect does nitrogen differ from oxygen?

3. State four characteristics of nitrogen.

4. Why does carbon burn faster in oxygen than in air?

5. Air consists principally of oxygen and nitrogen. The water in the bottle represents the amount of oxygen there was in the bottle of air, and the nitrogen occupies the rest of the space.

a. About what fractional part of the air in the bottle was oxygen?

b. What fractional part of the air in the bottle is nitrogen ?

6. Expose to the air of the room for a half hour or more a dish with some clear lime water.

$a$. Dèscribe the experiment, stating the effect on the lime water.

$b$. What substance does this experiment prove to be present in air? 


\section{Definitions}

14. A chemical element is a substance that has never been separated into two or more different kinds of matter. ${ }^{1}$ Over seventy of these elements are known at the present time, and of these seventy, twelve are found constantly in the living substance of plants and animals. The most common of these twelve elements are carbon (symbol, C), hydrogen $(\mathrm{H})$, oxygen $(\mathrm{O})$, nitrogen $(\mathrm{N})$, sulphur $(\mathrm{S})$, phosphorus $(\mathrm{P})$, iron $(\mathrm{Fe})$, and calcium $(\mathrm{Ca})$, which is found in lime.

[In addition to the elements already studied $(\mathrm{C}, \mathrm{O}, \mathrm{H}, \mathrm{N})$, the others mentioned should be shown to students; and if time permits, some of these elements may be burned or oxidized in oxygen and the characteristics of the oxids thereby formed may be discussed.]

15. A chemical compound is a substance formed by the union of two or more chemical elements. - Two of the important compounds considered in biology are carbon dioxid (formula $\mathrm{CO}_{2}$ ), which means that it is composed of one part of carbon and two parts of oxygen, and water (formula $\mathrm{H}_{2} \mathrm{O}$ ), which means that it is composed of two parts of hydrogen and one part of oxygen.

16. A mixture differs from a compound in the fact that the elements or compounds of which the former is composed are not chemically united. - In air, for instance, the oxygen and nitrogen are not chemically combined, but are simply put together as one might mix pepper and salt. Again, when sugar is dissolved or mixed with water, the two compounds are mingled so closely that the sugar disappears; it may easily be obtained unchanged in its composition by evaporating the water.

1 There are, however, exceptions to this statement, but they are too technical for discussion in an elementary text-book. 
17. Oxidation is the chemical union of oxygen with some other substance. - It may take place slowly, as when carbon is made to glow in the air ; or it may take place rapidly, as when carbon burns in oxygen. But whenever oxidation takes place, (1) an oxid is formed, (2) a certain amount of heat is produced, and (3) if the process is sufficiently rapid, a flame is seen.

\section{A Study of the Food Substances}

18. Introduction. - The food substances needed by plants and animals may be divided into five classes, namely: (1) carbohydrates (i.e. starches and sugars); (2) fats and oils; (3) proteins, ${ }^{1}$ which are also known as albuminous or nitrogenous substances (e.g., white of egg, lean meat, gluten of wheat); (4) minerals (e.g. common salt, saltpeter, phosphate of lime); (5) water.

19. To determine the chemical composition of starch. Laboratory Study No. 6. Suggested as home work.

Warm some starch in an old cooking spoon in order to drive off any water that may be in it, but do not allow it to burn. To determine when the starch is free from water, hold the heated starch under a dry, cold tumbler, and if no moisture collects upon the tumbler, the starch contains no water. Now set the starch on fire, and hold a cold, dry glass over the burning starch.

1. Tell what you have done and state what is formed on the inside of the tumbler by the burning of the starch.

2. What is the only chemical element that could possibly form water by burning (i.e. by uniting with oxygen)?

3. What chemical element, therefore, must have been present in the starch in order to have produced water when dry starch is burned?

1 The term protein is used throughout this book instead of proteid, because of the unanimous recommendation in favor of the former term by the American Society of Biological Chemists and the American Physiological Society. See Science, April 3, 1908. 
4. What substance is left in the cooking spoon after the flame goes out?

5. Name two chemical elements present in starch.

6. Starch also contains oxygen. Name now the three chemical elements of which this nutrient is composed.

20. To determine the chemical composition of sugar, fat, and protein. - Laboratory Study No. 7. (Optional.)

1. Test sugar in the same way as directed in Laboratory Study No. 6, 1-5 (above).

a. Describe each of the experiments, giving results and conclusions.

$b$. Sugar, like starch, has oxygen also in its composition. Name now all the chemical elements of which sugar is composed.

2. In a similar way test a fat (e.g. lard, or the fat of meat).

$a$. State what you do, what you see, and what you conclude.

$b$ : Fat, like starch and sugar, has oxygen in its composition, but in a different proportion. State, therefore, the three elements present in fat.

3. (Demonstration.) Secure a vegetable protein (e.g. gluten) and test it as directed above.

a. Describe your experiments and give your results and conclusions.

b. Besides the two elements you have shown to be present, protein also contains oxygen, nitrogen, sulphur, phosphorus, and often other elements. State, now, the chemical elements of which this food substance is composed.

21. Summary. - The carbohydrates, as we have learned and as their name implies, are composed of the chemical elements carbon, hydrogen, and oxygen. The same three chemical elements are likewise present in fats and proteins, but in different proportions. Proteins, however, in addition to the carbon, hydrogen, and oxygen, contain at least three other 
chemical elements, namely, nitrogen, sulphur, and phosphorus; in fact, proteins are the most complex of all chemical substances known.

Following is the composition of the various nutrients studied thus far:

Starch, composed of C, H, O (in the proportion of $\mathrm{C}_{6} \mathrm{H}_{10} \mathrm{O}_{5}$ ). Sugar, composed of C, H, O. (Grape sugar $=\mathrm{C}_{6} \mathrm{H}_{12} \mathrm{O}_{6}$.)

Fat, composed of $\mathrm{C}, \mathrm{H}, \mathrm{O}$.

Protein, composed of C, H, O, N, S, P (and sometimes of other elements).

22. Tests for the food substances. - Having demonstrated that the various food substances are chemical compounds, each composed of several chemical elements, we are now to carry on experiments by which it will be possible to test for each of these food substances. By this means we shall be able to prove the presence or absence of starch, grape sugar, protein, fat, mineral matters, and water in the foods used by plants, animals, and man.

23. To test foods for starch. Laboratory Study No. 8 .

Materials: Corn starch, grape sugar, white of egg, fat or oil, salt, water; various foods in the home kitchen; iodine solution (see below); test tubes; gas burner or alcohol lamp.

Preparation of iodine solution: A quart (1000 cc.) of iodine solution is made by dissolving in 5 teaspoonfuls $(40 \mathrm{cc}$.) of water, onehalf teaspoonful (4 grams) of potassium iodide, and one-fourth this amount of iodine (1 gram). This solution, when thoroughly mixed, should be diluted to make one quart (1000 cc.). In a clean bottle this mixture will keep indefinitely. ${ }^{1}$

1. Put a small amount (size of a pinhead) of corn starch in a test tube, add water, shake the mixture, and boil it over a gas flame. Pour into the starch mixture

1 From Peabody's “Laboratory Exercises." Henry Holt \& Co. 
thus formed a few drops of iodine. What color is produced?

2. Try the effect of iodine on each of the other food substances as follows: Put a small amount of grape sugar into a test tube; into a second tube put some white of egg (protein); into a third some fat or oil ; into a fourth some mineral matter (salt); and into a fifth some water. Add a little water to each and boil as in 1 above to cook each nutrient. Add a drop or two of iodine solution to each test tube.

Do any of the colors thus produced resemble at all the color resulting from the addition of iodine to starch?

3. From the preceding, state how you can determine whether or not a substance contains starch.

4. (Optional home work.) Test as many foods as you can (e.g. oatmeal, flour, raw meat, milk, parsnip, potato, onions, apples, beans, rice, pepper) in the following way: Put a small amount of a given food into a test tube or in a sauce pan, add a little water, and boil to cook each food, then add a few drops of iodine. Before making each test make sure that the test tube or saucer is clean. Prepare in your note-book a table like the following, and fill in under each head the names - of the foods you have proved to contain or to be without starch.

\begin{tabular}{l|l|}
\hline Starch Pregent & Starch Absent \\
\hline & \\
\hline
\end{tabular}

24. To test foods for grape sugar. Laboratory Study No. 9.

Materials: Grape sugar, corn starch, white of egg, fat or oil, salt, water; various food substances common in home kitchen; Fehling's solution (see below); test tubes, gas burner or alcohol lamp. 
Preparation of Fehling's Solution:-To make Fehling's solution dissolve 3 teaspoonfuls (34.64 grams) of pure pulverized copper sulphate (blue vitriol) in a little less than a half-pint of water $(200 \mathrm{cc}$.). Make a second solution by dissolving in a pint $(500 \mathrm{cc}$.) of water twelve heaping teaspoonfuls (150 grams) of Rochelle salt and 3 (5inch) sticks of caustic soda (50 grams). Fehling's solution does not keep for any great length of time, and hence must be made up fresh a short time before it is needed. To do this, thoroughly mix two volumes of the copper sulphate solution and five volumes of the solution of Rochelle salt and caustic soda, and dilute the mixture with an equal volume of water. It is more convenient to prepare it in small quantities from the tablets that may be obtained of druggists. Before making any tests boil a small quantity of the Fehling's solution in a clean test tube. If it retains its transparent blue color, it is ready for use; otherwise a fresh supply must be prepared. ${ }^{1}$

1. Dissolve a small amount of grape sugar (glucose) in water in a test tube. Add some Fehling's solution and boil. What change in color do you notice?

2. Try the effect of Fehling's solution on each of the other food substances as follows: Put a small amount of starch into a test tube; into a second tube some white of egg; into a third tube some fat or oil; into a fourth tube some mineral matter (salt); and into a fifth tube some water. Add a little water to each tube, then pour in a small amount of Fehling's solution and boil as in 1 above. Do any of the colors produced resemble at all the color of the Fehling's solution when it was boiled with grape sugar?

3. From the preceding experiments state how you can determine whether or not a substance contains grape sugar.

4. (Optional.) Test as many foods as you can (e.g. onions, grapes, pears, granulated sugar, honey, molasses, parsnip, raw meat, milk, egg) in the following manner: Put a small amount of a given food into a test tube, add a little water, and a

${ }^{1}$ From Peabody's "Laboratory Exercises." Henry Holt \& Co., New York. 
small spoonful of Fehling's solution, and boil. Before making each test make sure that the test tube is clean. Prepare in your note-book a table like the following, and fill in under each head the names of the foods you have proved to contain or to be without grape sugar.

\begin{tabular}{l|l}
\hline Grape Sugar Pregent & Grape Sugar Absent \\
\hline & \\
\hline
\end{tabular}

25. To test foods for proteins (albuminous or nitrogenous' substances). - Laboratory Study No. 10.

Materials: White of egg, corn starch, grape sugar, mutton tallow or other fat, salt, water; piece of meat, milk; concentrated nitric acid, ammonia; test tubes; gas or alcohol lamp.

1. Pour a little concentrated nitric acid on a piece of hard boiled egg in a test tube.

a. What change in color of the egg do you observe?

b. (Optional.) Wash the egg with water, add a little concentrated ammonia, and note result.

2. Try the effect of nitric acid on each of the other food substances as follows: Put a small amount of starch into a test tube; into a second tube some grape sugar; into a third some mutton tallow or other fat; into a fourth some mineral matter (salt); and into a fifth tube some water. Add a little concentrated nitric acid to each of these foods. Is any color produced like that resulting from adding nitric acid to protein? (In case a liquid is to be tested with nitric acid, the mixture should be boiled before deciding whether protein is present or absent.)

3. From the preceding experiments state how you can determine whether or not a food contains protein. 
4. (Optional.) Prepare in your note-book a table like the following, and place in the proper columns the names of the foods tested in class.

26. To test foods for fats. - Laboratory Study No. 11. Suggested as home work.

Materials: Butter or olive oil, corn starch, grape sugar, piece of boiled white of egg, salt, water; various foods in the home kitchen, including nuts.

1. Put on a piece of paper a piece of butter half the size of a pea (or a drop of olive oil). Put the paper in a warm place (e.g. in a hot oven or over a heated radiator) for a few moments, then hold the paper between yourself and the light. How is the paper affected by the fat?

2. Try the effect of each of the other food substances (starch, grape sugar, piece of boiled egg, i.e. protein, salt, i.e. mineral matter, water) on paper, by adding an equal quantity (half the size of a pea) of each to separate pieces of paper. Put the pieces of paper in a warm place as in 1 above. Hold each piece between yourself and the light. Do any of these food substances affect the paper as did the fat?

3. From the preceding experiments state how you can determine whether or not a food contains fat.

4. (Optional.) Prepare in your note-book a table like the following, and place in the proper columns the names of the foods tested at home or in class. 


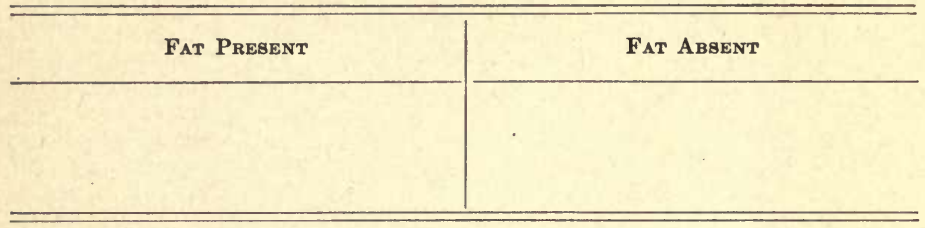

Note. In case a food which is being tested may possibly contain a small amount of fat, the food should be pulverized, shaken in a test tube with ether or benzine (to dissolve out the fat), and allowed to stand for $\mathbf{2 4}$ hours. The clear liquid should then be poured upon paper, and the ether or benzine allowed to evaporate.

Caution. Never handle ether or benzine near a flame or hot stove, since the vapor of these substances is very inflammable.

27. To test foods for mineral matter. Laboratory Study No. 12. Demonstration.

Materials: Salt, corn starch, grape sugar, piece of boiled egg, butter or fat, water.

1. Place a piece of salt half the size of a pea on an old cooking spoon and heat over as hot a flame as possible. Does the salt burn and disappear?

2. In the same manner try the effect of heat on the other food substances (starch, grape sugar, white of egg, fat, water). Do any of these substances burn or disappear?

3. From the preceding experiments state how you can determine whether or not a food contains mineral matter.

4. (Optional home work.) Test at home in the same manner as described in 1 above a match stick and a leaf. Do these plant materials contain mineral matters? How do you know?

28. To test foods for water. - Laboratory Study No. 13. Home work.

1. Warm a little water on a spoon and place over it a dry, cool, tumbler. What do you see on the inside of the glass? How, then, can you tell whether or not water is found in a given food? 
2. (Optional.) Test as many foods as you can by warming in turn a small quantity of each in a spoon (without letting the food burn), and holding over the spoon a dry, cool tumbler. What do you learn as to the presence of water in foods?

3. (Optional Demonstration.) To determine the amount of water in potatoes:

a. Remove a thin layer of peel from a potato, weigh the potato, and lay it aside in a warm dry place (protected from mice). Weigh each day, and fill out in your note-book for each day the first, third, and fifth columns in a table like the following :

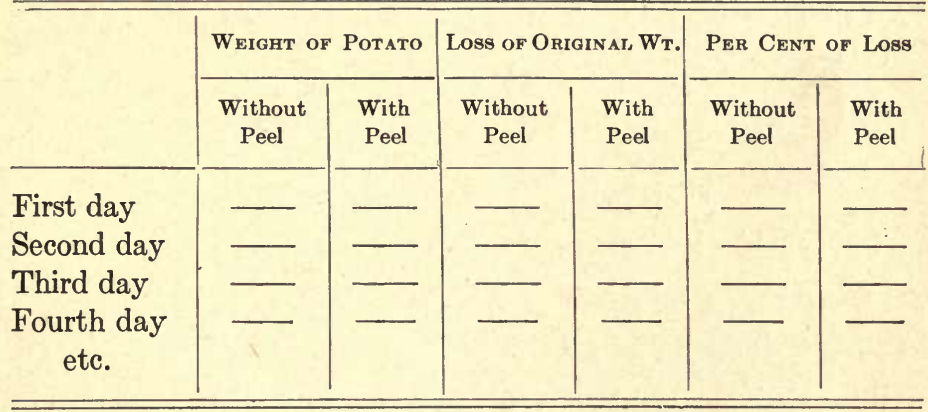

$b$. Secure a second potato about the same size as the first, weigh it each day, and place it beside the potato that was peeled. Record results and percentages for each day in second, fourth, and sixth columns of preceding table.

c. Which of the two potatoes decreases in weight the more rapidly? Almost all the loss of weight is due to the evaporation of water; what do you infer, therefore, as to one use of the peel?

$d$. Continue to weigh the potato without the peel at intervals until there is no further loss. What percentage of potato is water? When potatoes are bought at $\$ 3$ per barrel, how much of this sum is paid for water? 
IV. Manufacture of the Food Substances by Plants

29. Is starch present in the green leaves of a plant that has been exposed to sunlight? - Laboratory Study No. 14 .

Take several leaves from a vigorous plant (e.g. geranium, hydrangea) which has been exposed to bright sunlight for a number of hours. Boil them a few moments in a large test tube or flask of water; pour off the water, add alcohol, and boil carefully over a piece of wire gauze or asbestos until all the green coloring matter has been removed. Rinse the leaves in water, add iodine solution, and spread the leaves on saucers, or in Petri dishes.

1. Describe in your own words how the experiment was performed.

2. Is starch present in the leaves? How do you know?

3. Why was it necessary to remove the green coloring matter from the leaves before testing for starch? (If you are in doubt, add some iodine to green leaves.)

4. (Optional.) How may grass stains be removed from clothing?

30. Is starch present in the green leaves of a plant that has been deprived of sunlight? ${ }^{1}$ - Laboratory Study No. 15.

Put a vigorous plant (e.g. fuchsia, squash, sunflower, or bean seedling) in darkness for 48 hours or more. Remove several leaves, and treat them as described in 29 above.

1. State briefly how the preparation of this experiment differs from that in the previous experiment.

2. Give your observation and conclusion.

3. State, therefore, whether sunlight is or is not necessary for the manufacture of starch in green leaves.

31. Is starch present in colorless portions of green leaves? - Laboratory Study No. 16.

${ }^{1} \mathrm{~A}$ most suggestive series of experiments on the formation of starch in green leaves is found in the Botanical Gazette for September, 1909, pp. 224-228, by Sophia Eckerson, of Smith College. 
Secure a plant having some portions that are colorless (e.g. striped grass). Expose the plant to sunlight for two or three hours, then remove several leaves and test them in the same manner as described in 29 above.

1. State briefly how the preparation of this experiment differs from that of the two preceding experiments.

2. What is your observation and conclusion as to the presence of the starch in the green and colorless portions?

3 . State, therefore, whether green material is or is not necessary for the manufacture of starch.

This green material in leaves is called chlorophyll (from Greek chloros $=$ green + phullon $=$ leaf) .

32. Is carbon dioxid necessary for starch manufacture in leaves? - Laboratory Study No. 17.

Secure two vigorous potted plants, two bell-jars large enough to go over the plant and pot, and two trays or other receptacles having a greater diameter than that of the bell-jar. Place the plants in darkness for 24 hours at least, so that the leaves may be free from starch (see $\mathbf{3 0}$ above). Now test the leaves of both plants to make sure they are free from starch. Into one tray pour a quantity of lime water and into the other tap water. Put the plants on supports of some kind so that the pots will not touch the liquid, and cover with the bell-jars. (See Fig. 3.) Be sure that the edges of the belljars are covered with the liquid, so that no air can enter the jars. Place both preparations where the plants can get no sunlight for 24 hours in order to give time for the absorption of carbon dioxid in the jar with the lime water. Place both preparations in strong sunlight for several hours. 
1. Describe the preparation of the experiment.

2. Examine the lime water inside the bell-jar. What proof have you that carbon dioxid has been absorbed?

3. Remove a leaf from each of the plants and test for starch. Tell what was done and state your observations. Which leaf, therefore, contains starch?

4. What is your conclusion as to the necessity of carbon dioxid for starch manufacture?

5. What chemical elements that are present in starch might be furnished by the carbon dioxid $\left(\mathrm{CO}_{2}\right)$ ?

6. The other raw material needed by plants for the manufacture of starch is water $\left(\mathrm{H}_{2} \mathrm{O}\right)$. What third chemical element found in starch must be furnished by water?

7. Now name the two raw materials used by plants in the manufacture of starch and state the chemical elements which each can furnish.

33. Manufacture of carbohydrates. - The substance first made by the combination of carbon, hydrogen, and oxygen in the leaves is not starch, but a simple carbohydrate which is then made into grape sugar. When the plant manufactures more sugar than it needs for immediate use, the surplus is changed to starch, and this is what we have found stored in the leaves.

34. Manufacture of proteins. - We have already learned that proteins contain carbon, hydrogen, oxygen, nitrogen, and usually sulphur and phosphorus (see 21). The plant, therefore, must somehow obtain these elements in order to manufacture proteins. It has been proved that plants manufacture sugar, and this probably supplies the necessary carbon, hydrogen, and oxygen. The nitrogen that is needed is furnished by compounds containing nitrogen such as saltpeter (potassium nitrate, $\mathrm{KNO}_{3}$ ), and the sulphur and phosphorus are secured from mineral compounds known as sulphates and phosphates. These compounds are derived from soil water. From these compounds, namely, sugar and the 
mineral matters containing nitrogen, sulphur, and phosphorus obtained from the soil, the living plant manufactures protein.

35. Do green plants give off a gas in sunlight? - Laboratory Study No. 18.

Into a glass cylinder containing water fresh from the faucet put a small amount of water plant (Elodea, Spirogyra, or Milfoil), holding it to the bottom of the tall jar by means of a weight if necessary. Stand the cylinder in direct sunlight.

1. Describe the preparation of the experiment.

2. What do you observe coming off from the plant? (These bubbles of gas have been proved to be composed of oxygen.)

36. Do green plants give off a gas when deprived of sunlight? - Laboratory Study No. 19.

Place the glass cylinder prepared as directed above in darkness for several hours (or, still better, a second cylinder should be used for comparison).

1. In what respects do Experiments 18 and 19 differ?

2. Do you see any bubbles as long as the cylinder is kept in the dark?

3. Under what condition, therefore, does a green plant give off oxygen?

37. The oxygen supply for animals. - We have seen that starch is made of carbon dioxid $\left(\mathrm{CO}_{2}\right)$ and water $\left(\mathrm{H}_{2} \mathrm{O}\right)$. By repeated experiments biologists have proved that in the process of manufacturing carbohydrates more oxygen is present in the $\mathrm{CO}_{2}$ and $\mathrm{H}_{2} \mathrm{O}$ than is needed. This is the oxygen we have seen given off by the green water plant in sunlight. Every green plant gives off oxygen into the air when manufacturing carbohydrates. Hence, in this process the carbon dioxid is constantly being taken from the air and a fresh supply of oxygen set free. 


\section{CHAPTER III}

\section{THE STRUCTURE OF PLANTS}

38. The parts of a plant. - Laboratory Study No. 20.

Materials: A well-developed bean plant or other seedling or a weed, for each two pupils; one or more plants with flowers and if possible with fruits for demonstration.

Nearly all the plants with which we are most familiar consist of at least three kinds of

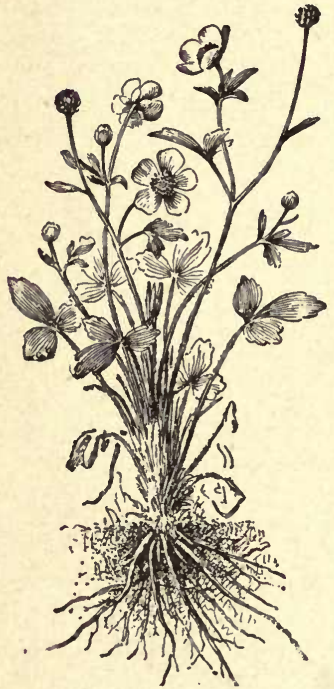

FIG. 4. - Roots, stems, leaves, flowers, and fruits of a buttercup plant. parts, namely, roots, stems, and leaves (Fig. 4).

1. Name and describe as to color and form the parts of the plant that grew beneath the ground.

2. How does the stem differ from the root as to color and direction of growth? What parts of the plant above ground are attached to the stem?

3. How does the main part of the leaf differ in form from the root or the stem?

4. Make a drawing, natural size, of the plant you are studying, labeling ground level, roots, stem, leaf.

5. On the plants used for demonstra tion, what parts besides those named above do you find? How do the colors of these parts differ from the color of the rest of the plant? 
39. Organs and functions. - From our laboratory study we have learned that a common plant consists of roots, stems, and leaves, and that at certain seasons of the year flowers and fruits are present. To each of these various parts is given the name organ. Roots are useful to a plant, for one thing, because they hold it in the ground, while stems support the leaves, flowers, and fruits. In fact every organ of a plant has some work to do, and this work is called its function. Hence, we may define an organ as a part of a plant that has a certain function or functions to perform.

40. Microscopic structure of plants. - When one examines by the aid of a compound microscope a small portion of any of the organs of common plants, one finds that each organ is composed of many smaller portions too minute to be seen with the unaided eye. These tiny divisions are called cells. We shall now attempt to become familiar by the use of the compound microscope with the appearance of several kinds of plant cells.

\section{Study of plant cells. - Laboratory Study No. 21.}

Materials: (1) Slides prepared as follows: Cut a layer of an onion bulb into small squares, and strip off from the inner surface of each square a very thin layer. Place it on a glass slide and add a drop of water. (If it is desirable to keep the slides for several hours, put glycerin diluted with water over the onion cells.) Cover each thin membrane with a cover glass. ${ }^{1}$ (2) Prepared or freshly cut thin sections of roots, stems, and leaves.

1. By the aid of the low power of the compound microscope, examine the slide prepared as directed in (1) under materials. Note that the thin membrane is composed of a large number of tiny spaces each in-

1 The authors are indebted to Miss Elsie M. Kupfer, Head of Department of Biology of Wadleigh High School, New York City, for suggesting this admirable material for cell study. 
closed by lines more or less dark in color called cell-walls. (These parts are usually seen more clearly if the light is largely excluded by closing the diaphragm in the stage.)

$a$. Describe the general appearance of the membrane, stating of what it is composed.

$b$. State whether or not the cells in the various parts of the membrane differ in size and shape.

2. The cell-wall incloses a semifluid substance which makes up the cell-body. Describe the appearance of the cell-body.

3. Within the cell-body, often near the center of the cell, is usually a tiny object called the nucleus. Describe the location, shape, and color of the nucleus.

4. Make a drawing of three or four adjacent cells, several times as large as they appear under the microscope. Label cell-wall, cell-body, cell-nucleus.

5. (Demonstration.) Secure some growing sprays of Elodea (a common water plant). Pull off one of the youngest

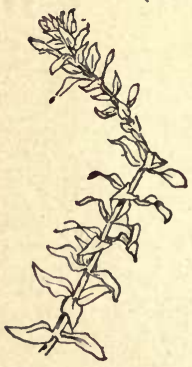

Fig. 5. - Elodea plant. leaves near the tip end, put it on a slide with a drop of water, and cover with a cover glass. Let the preparation stand in a warm place for a time. Examine with the high power the cells of which this leaf is composed.

Within each cell note some green bodies called chlorophyll bodies (from Greek, meaning leaf green). These are the bodies which aid in starch manufacture in green leaves. (See 31.)

a. Describe the form, color, and use of chlorophyll bodies.

b. Carefully watch the chlorophyll bodies in several cells and describe any movements you see. These movements show that the substance of the cell is in motion, and is carrying the chlorophyll bodies along with it.

c. Make a drawing at least 2 inches long of one of the cells with its chlorophyll bodies. Label cell-wall, 
chlorophyll bodies, and show by arrows the direction of their movements.

6. (Demonstration.) Examine with the low power of the microscope the sections of root, stem, and leaf, or study Figures $11,12,15,22$. Write a paragraph on the microscopic structure of root, stem, and leaf.

(Optional.) Make a drawing of four or five cells from each of the organs studied.

42. Cells and protoplasm. - Under the microscope cells at first appear to be only plane surfaces surrounded by lines. In reality, however, each cell has not only length and breadth, but also thickness, and each cell is covered on all sides by a cell-wall which is composed of a lifeless substance known as cellulose. This wall is often so transparent that we can look through it and see the cell-body and nucleus within (Fig. 6).

The discovery of these minute bodies of which organs are composed was not made until about the middle of the last century (1848). With the rather imperfect microscopes then in use the two discoverers, Schleiden and Schwann, could see the cell-walls only, and they did not know, as we now know, that the most im-

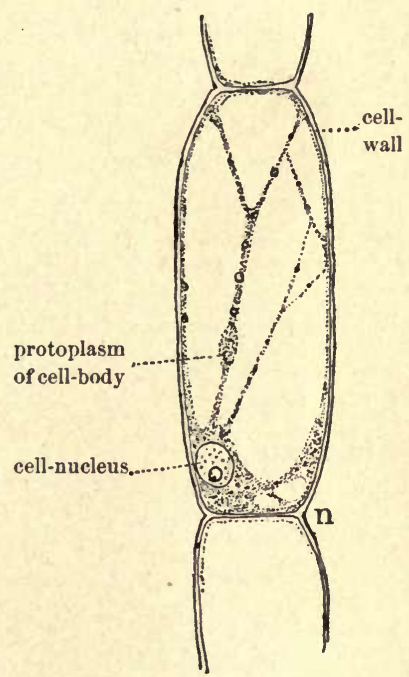
FIG. 6. - Plant cell. The spaces in the cell-body are filled with cell-sap.

portant part of the cell is not the lifeless wall of cellulose, but the living substance which is found inside the cell-wall, making up a large part of the cell-body and cell-nucleus. 
To this substance is given the name protoplasm. We know now that the living substance or protoplasm is the essential part, while the wall may be missing, so that in such a case there is no resemblance to a cell or box. Biologists now understand $a$ cell to be a bit of protoplasm (cell-body) containing a nucleus (which is a denser portion of the protoplasm).

Protoplasm, when examined with the highest powers of the microscope, appears as a colorless, semifluid substance, in which are often seen solid particles or granules, which are probably little masses of food. The nucleus, as already stated, is commonly found near the center of the cell, and is composed of protoplasm denser than the protoplasm of the body of the cell. The appearance and composition of the protoplasm may be well represented by raw white of egg; but in making this comparison one should bear in mind that the white of an egg is not living substance.

Within the cell, too, and occupying some of the space outside the nucleus, especially in plant cells, is cell-sap, which is a lifeless fluid composed of water in which are dissolved the food substances (such as sugar and mineral matters) used by cells in their growth and repair, and in the various kinds of work which they carry on (Fig. 6).

43. Assimilation, growth, and cell division. - To make protoplasm the plant must have proteins, water, and additional compounds containing iron, calcium, and several other chemical elements. But only protoplasm has the power to combine these compounds in such a way as to form living matter. Bearing in mind the facts we learned in studying food manufacture (33 and 34), we see that the plant begins with simple substances, water and carbon dioxid, and manufactures a more complex substance, sugar. It uses this and other substances to make a still more complex substance, 
protein, and finally ends by making the most complex of all, protoplasm. But, except in rare cases, all plants must have compounds to start with; they cannot make any of these nutrients or protoplasm from chemical elements.

And thus we learn that food materials are gradually changed by protoplasm into living substance like itself. To this process is given the name assimilation (Latin, $a d=$ to $=$ similis $=$ like). As a result of the process of assimilation the amount of protoplasm of courseincreases and the cell grows. Were
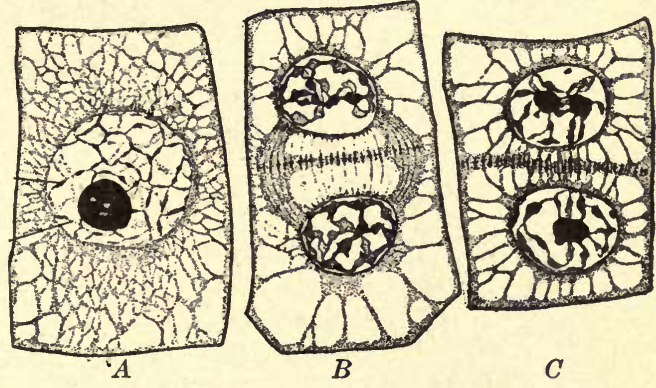

Frg. 7. - Cell division.

$A$, cell before division; $B$, cell with divided nucleus ; $C$, single cell that has divided into two cells.

this process to continue indefinitely, cells would become large in size. This, however, does not occur; for when a cell reaches its normal size, the nucleus divides, and the halves separate from each other to form two nuclei. The cell-body now divides into two parts, and cell-walls are formed between the two cells (Fig. 7). Thus are produced two cells, each having its own nucleus, and these in turn assimilate, grow, and divide. In this way the number of cells increases with the growth of the plant. 


\section{CHAPTER IV}

\section{OSMOSIS AND DIGESTION}

Materials: Four thistle tubes, four wide-mouthed bottles; honey, molasses, or a thick solution of grape sugar; starch (arrowroot. if possible), diastase ; white of egg, peptone ; iodine, Fehling's solution, nitric acid. Procure the intestines of calf or beef, wash them thoroughly inside and out, and inflate them by the aid of a glass tube. Tie at intervals of two or three feet, and allow this animal membrane to dry. Cut off pieces about two inches long, and slit open

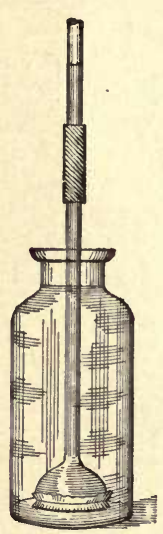

Fig. 8. - Apparatus for thistle tube No. 1 in osmosis experiment. each of the pieces thus obtained. Membrane prepared in this way may be kept in closed bottles for years. If desired, the pieces of membrane may 'be used at once without drying. Sausage coverings that have been preserved in salt may be thoroughly washed, dried, and used.

Thistle tube No. 1.- Hold one of the thistle tubes upright, closing the smaller end by pressing on it with the thumb. Into the larger end pour the honey, molasses, or grape sugar solution, which has been sufficiently warmed to pour easily. Half fill the tube and nearly fill the bulb. Moisten one of the pieces of intestine and tie it tightly over the bulb of the thistle tube so that none of the liquid can escape. Wash off any of the liquid from the outside of the membrane, then dry it with a blotter, and hold the thistle tube bulb down for several minutes to make sure that the grape sugar solution does not leak out. Now stand the 
tube, membrane down, in one of the wide-mouthed bottles and fill it with water up to the neck. Add grape sugar solution to the thistle tube until the level of the water in the bottle and that of the liquid in the thistle tube is the same. Connect a long piece of glass tubing to the upper end of the inverted thistle tube, and support this tube in a vertical position, so that the membrane does not touch the bottom of the bottle (Fig. 8).

Thistle tube No. 2. - Set up a control experiment exactly like No. 1, except that water should be put into the thistle tube as well as in the bottle.

44. Will water pass through a membrane? - Laboratory Study No. 22.

1. Give in your own words a description of the way thistle tube No. 1 was prepared, making a diagram of the apparatus, and labeling level of water in bottle and of grape sugar solution in thistle tube at the beginning of the experiment.

2. At the end of a few hours compare the level of the liquid in thistle tube No. 1 with the level in thistle tube No. 2.

a. How many inches has the grape sugar risen in No. 1 ?

$b$. Is there a similar rise in the water in thistle tube No. 2 ?

c. What must have passed into thistle tube No. 1 to cause the liquid to rise?

d. Through what must this liquid have passed to get into the thistle tube?

3. Do you conclude, therefore, that water will or will not pass through a membrane?

45. Will grape sugar pass through a membrane? - Laboratory Study No. 23.

1. At the end of a few hours test the liquid in bottle No. 1 by putting a glass tube to the bottom of the bottle, pressing the thumb over the top of the tube, and removing the sample of liquid thus obtained to a clean test tube; add Fehling's solution and boil. 
a. Describe what was done.

b. Is grape sugar present now? How do you know?

c. What must have happened to produce this result?

2. We have now proved that two different liquids have passed through the membrane.

a. Name these two liquids.

$b$. Which of these two liquids has passed through the membrane in the greater quantity? How do you know?

c. Which of these two liquids is the thicker or denser?

d. By a great many experiments it has been proved that, when any two liquids of different density are separated by a plant or animal membrane, results similar to those noted above follow. To this interchange of liquids is given the name osmosis. In this process of osmosis, is the greater flow of liquid from the less dense to the more dense, or from the more dense to the less dense?

$e$. Why did not the water rise in thistle tube No. 2 ?

3. Do you conclude, therefore, that grape sugar will or will not pass through a membrane?

46. Osmosis in living cells. - Laboratory Study No. 24.

Peel a potato and then cut several cross sections about $\frac{1}{8}$ inch in thickness.

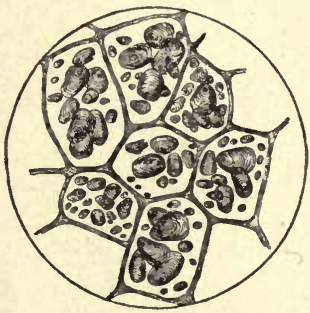

FIG. 9. - Cells from a potato, showing cellwalls, cell-sap, and starch grains of different sizes.
Allow these sections to stand in the air until they bend readily. Half fill one tumbler with water and a second tumbler with a strong solution of sugar or salt. Place some of the sections in each of the two tumblers and leave them for several hours.

1. Describe the preparation of this experiment.

2. Remove a section of potato from each of the liquids and bend them. Compare the change that has taken place in the rigidity or stiffness of the sections placed in the strong solution and those in the tap water. 
4. Potato sections, like those of all parts of living plants, are composed of a large number of living cells, each one inclosed by a cell membrane (Fig. 9).

Call to mind what you learned in 45 , and state why the cells become even more flabby in one solution and more rigid in the other.

47. Will starch pass through a membrane? - Laboratory Study No. 25.

Thistle tube No. 3. - Put into a third thistle tube a mixture of starch and water, cover the bulb with a membrane, and invert in a bottle of water, as already directed for the first thistle tube. See that the level of the liquid is the same in all of the experiments.

1. In what respects does the preparation of thistle tube No 3 resemble that of No. 1? How do the two experiments differ?

2. At the end of a few hours test the liquid in bottle No. 3 by removing a sample to a test tube (as already directed in 45), and adding iodine solution.

a. Is starch present? How do you know?

$b$. What is your conclusion as to the possibility of starch passing through a membrane?

3. What have these experiments in osmosis taught you as to one difference between starch and grape sugar?

48. Definitions and applications. - The experiments we have been performing have most important relations to the study of all living plants and animals. We may give the following as a definition of the process we are considering: Osmosis is the interchange of liquids of different density that are separated by a plant or an animal membrane, and in this process the greater flow is always from the less dense to the more dense.

We shall constantly refer to this principle of osmosis, and we shall find that it explains in large measure the absorption of soil water by roots, the transfer of sap from one part of a 
plant to another, as well as the processes by which the blood of animals obtains and gives off food to various cells of the body.

By the preceding experiments we have proved that there are two classes of food substances. One kind (including water and grape sugar) will readily pass through a membrane by osmosis; the other kind (represented by starch) will not. In our study of cells we learned that the protoplasm or living substance is inclosed by a cell-wall which separates one cell from another. Now if cells are to make use of the food materials manufactured in other parts of the plant, each food substance must be in such a form that it can pass through these cell-membranes. It is evident that water and grape sugar can do this. We find, however, large quantities of starch stored in cells (Fig. 9). Hence, to be available for use in other cells, some change must be made in this food substance before it can be transferred from cell to cell. We shall now show by experiment what this change is.

\section{How starch is made ready to pass through a membrane.} - Laboratory Study No. 26.

Into each of two test tubes put a small amount of starch (arrowroot starch if it can be obtained), add some water, shake, and boil. To the starch mixture in one test tube add some diastase, equal in amount to one-half the size of a pea. (Diastase is a chemical substance produced or secreted by the protoplasm of plant cells.) Put the two test tubes side by side in a warm place for 5 minutes if arrowroot starch, 24 hours if corn starch is used, then test a small amount of the mixture in each test tube by adding a few drops of iodine.

1. Describe in your own words what has been done.

2. In which test tube do you find starch present?

3. Now test with Fehling's solution a small quantity of each mixture. In which tube do you find grape sugar? 
4. What do you conclude, therefore, as to the effect of diastase on starch?

5. Why is this change necessary if starch is to be used by plants?

50. To prove that starch is made soluble in growing plants.

- Laboratory Study No. 27.

1. Pound two or three corn grains into a powder and put some of this corn meal into a test tube, add water, and boil. To one-half of the mixture add iodine, and to the other half, Fehling's solution, and boil. Give a careful description of the experiment and state your observations and conclusions.

2. Secure some germinating corn grains, cut them into small pieces, and test some of them with Fehling's solution as in 1 above. Describe the experiment, stating your observations and conclusions.

3. The change in starch that you have described is known as digestion. What reason have you for believing that digestion of starch takes place when corn grains germinate?

51. Definition of digestion. - We may define digestion as the chemical change whereby insoluble food substances are made ready to pass through membranes and become ready for the use of protoplasm. Let us now by experiment determine whether or not protein needs digestion.

52. Will protein pass through a membrane? - Laboratory Study No. 28.

Thistle tube No. 4. - Secure some white of egg, cut it with scissors and mix it with water. (White of egg, we found, contains a large amount of protein.) Prepare the fourth thistle tube in the same way as directed for thistle tube No. 1, only using white of egg and water instead of grape sugar. See that the level of the liquid is the same as in thistle tube No. 2. 
1. In what respects does the preparation of thistle tube No. 4 resemble that of thistle tube No. 1 ? How do the two experiments differ?

2. Allow the experiment to stand for several hours, and then remove with a glass tube a sample of the liquid in bottle No. 4, and test it by adding nitric acid and boiling. Is protein present? How do you know?

3. Do you conclude, therefore, that protein will or will not pass through a membrane?

53. Digestive ferments. - We have stated that protoplasm secretes a substance called diastase, and have shown that this diastase will change insoluble starch to soluble grape sugar, which will pass from one cell to another by the process of osmosis. Diastase is a substance known as a digestive ferment. Now protoplasm produces other digestive ferments, some of which will change insoluble protein to a soluble substance known as peptone. The latter will readily pass by the process of osmosis through a membrane.

Fats, also, like starch and protein, are insoluble and cannot, therefore, pass by osmosis through cell walls. To make these food substances available for use they must also be changed by the plant cells into such forms that they may be readily transferred from one part of the plant to another. These changes are caused by other chemical ferments produced by protoplasm. 


\section{CHAPTER V}

\section{ADAPTATIONS OF THE NUTRITIVE ORGANS OF PLANTS}

54. The nutritive organs of plants. - From our study of food manufacture (29-34) we learned that the plant foods are produced in green leaves. Before this process of food manufacture can go on, however, the cells in the leaf must be supplied with raw materials from the air and from the soil. Since the roots, stems, and leaves are all concerned in food making, these organs are known as the nutritive organs of plants. Each of these organs has several functions; we shall now learn what some of these functions are, and how the nutritive organs are adapted for the work they do.

\section{The Structure and Adaptations of Roots}

55. The structure of roots. - Laboratory Study No. 29. A. Gross structure of roots.

Select the largest roots of a well-developed seedling or the roots of common weeds. By means of your thumb and finger nail gently scrape off the outer layers from a piece of one of these roots. When no more of the material can be easily removed by this method, pick to pieces the central part of the root which is left. The outer layer you have removed is largely composed of the cells of the cortex, and the central part that has been exposed is called the central cylinder.

1. Tell what you have done.

2. Which is composed of the tougher and harder material, the cortex or the central cylinder? 
3. Make a diagram greatly enlarged of a piece of root prepared as directed above. Label cortex, central cylinder, fibers of central cylinder.

\section{B. Root-hairs.}

Note to the Teacher. - Root-hairs may be grown for study as follows: Cover the bottom of as many Petri dishes as are needed with a layer of blue blotting paper. Soak the paper with water and lay several grains of soaked barley, oats, or corn upon the bottom of each dish. Put the covered dishes in a warm place for several days. When the root-hairs have developed, wipe the moisture from the inside of the covers, quickly replacing the latter. If Petri dishes are not available, two clean glasses of any convenient size may be used instead. Cover one of the plates with layers of wet blotting paper, put the soaked grains in position, and cover with the second glass, fastening the two together with threads or strings. Stand one end of the preparation thus made in a jar with enough water to reach the lower edge of the blotting paper.

Examine first with the naked eye and then with a hand magnifier the roots of sprouted grains, developed as described above. Notice tiny outgrowths from the sides of the roots; these outgrowths are called root-hairs.

1. Look at the very tip of the root and state whether root hairs are there present or absent.

2. State whether the root-hairs are longest near the tip or in the direction of the grain.

3. Make a drawing much enlarged to show the shape of one of the roots including the root-tip and the various lengths of root-hairs. Label root-tip, roothairs.

\section{Microscopical structure of the tip of a root.}

(Optional.)

Examine with the aid of the low power of the compound microscope a root-tip mounted on a slide in drop of water and covered with a cover glass. Make a sketch very much enlarged to show - 
1. The outline of the root including the tip.

2. A loose mass of cells covering the lower end of the root which make up the root-cap.

3. Label root-tip, cells of the root-cap.

56. The functions of roots. - Laboratory Study No. 30 .

A. Roots as organs for holding the plant to the soil.

Secure a vigorously growing plant in a pot (e.g. a rubber plant) or better try the following experiment on a good sized weed in a field. Attach to the stem just above ground level a spring balance. Pull on the balance until the plant shows signs of letting go its hold on the soil, then note the reading in pounds on the scale.

1. In your own words describe what was done.

2. How much force in pounds was exerted on the plant?

3. What important function of roots is shown by this experiment?

B. Roots as organs for absorbing soil-water.

(Before proceeding further with the root study, the osmosis experiments, 44-53, should be performed if they have not already been done.)

Study the diagram of a root-hair in the text-book (Fig. 12) and if possible examine with the low power of the microscope some of the younger (shorter) roothairs. Each root-hair is an elongated part of an outer cell of the root.

1. Draw in your note-book a diagram of a root-hair, labeling cell-wall, thin layer of protoplasm, cellsap, and nucleus.

2. What separates the soil-water from the cell-contents?

3. Recall the characteristics of cellular structure às given in 42. Now state which is the more dense, the soil-water or the cell-contents. 
4. In which direction, therefore, will there be the greater movement of liquid in the process of osmosis?

5. How, then, is a root-hair adapted by structure for absorbing soil-water?

C. Roots as organs for transmitting soil-water.

Place some seedlings or weeds in red ink so that only the lower ends of the roots are in the liquid. Cut some cross sections of these roots above the point where they were in contact with the ink. Examine the cross section of the root prepared in this way.

1. Describe the experiment as it was performed.

2. Through what part of the root (cortex or central cylinder) has most of the liquid passed? How do you know?

3. Make a sketch about an inch in diameter of the cross section of the root, to show the colored and colorless portions. Label: part of the root through which liquid traveled, unstained portion of root, cortex, central cylinder.

D. Roots as organs for the storage of food.

Cut some slices about an inch thick from parsnips or other fleshy roots, and divide each slice vertically in halves. Put the pieces in water and boil for a few moments to partially cook them. Pour iodine solution over some of the pieces; to others add strong nitric acid; boil still other pieces in a test tube with Fehling's solution.

1. Describe the preparation of each of the experiments, and state in each case your observations.

2. What do you conclude as to the presence or absence of each of three of the food substances in various parts of the fleshy root you are studying?

3. What function of roots do these experiments demonstrate?

57. Adaptations of roots for holding to the soil. - One of the most obvious functions of roots is that of holding plants firmly in the ground. If the soil is carefully removed from 
the roots of a weed or a tree, these roots will be found to extend outward in all directions to a distance even greater than do the branches above ground. When one remembers the tremendous force exerted upon trees by high winds, the necessity for this extensive root anchorage will be evident. In our dissection of the root even of a young plant we found

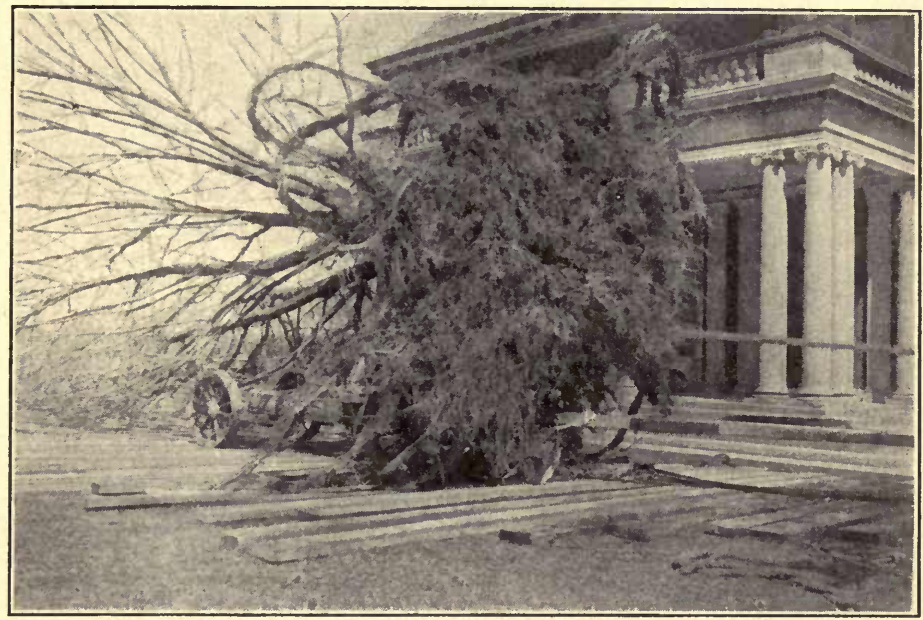

Frg. 10. - Roots of a tree, showing method of transplanting a large tree. (Courtesy of Isaac Hicks and Sons, Westbury, Long Island.)

that the central cylinder was composed of tough fibers which are made up of elongated wood-cells (similar to those shown in Fig. 15). As a plant grows older, these central cylinders become so thick and tough that they will resist an enormous strain without breaking.

58. Adaptations of roots for absorbing and transmitting soil-water. - A second function of roots we found to be that of absorbing soil-water and transmitting it to the stem. The 
whole outer surface of young roots is covered with a single layer of thin-walled cells which form the epidermis. Many of these cells develop tubular outgrowths known as root-hairs

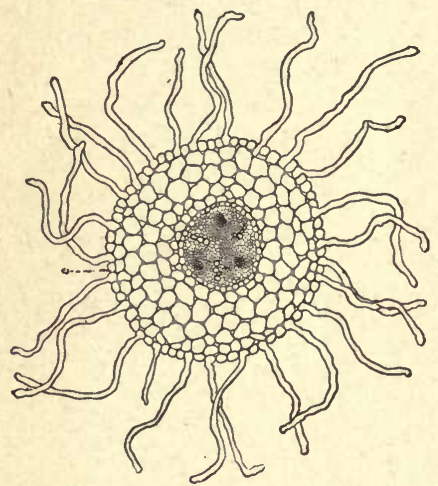

FIG. 11. - Cross section of root, showing root-hairs and epidermis cells on the outer surface, cells of cortex within, and woody central cylinder with its ducts. - (Bailey.)

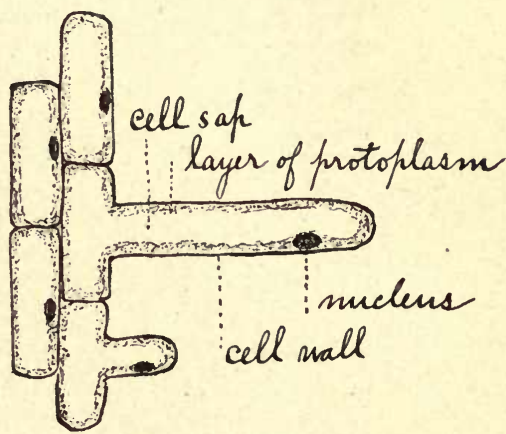

FIG. 12. - Diagram of a lengthwise section of two root-hairs with adjacent colls of the epidermis, and with two cells of the cortex.

(see 56, B). By studying Fig. 12 it will be evident that each root-hair consists of a cell-wall lined by a thin layer of protoplasm. The interior of the cell is largely filled with

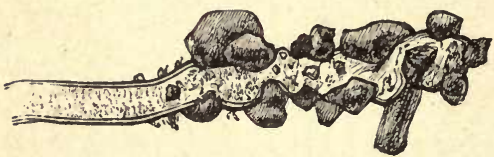

Fig. 13. - Portion of a root-hair with adhering particles of soil. - (Strasburger.) cell-sap. On the outside of each root-hair is soilwater. All the conditions necessary for osmosis are therefore present. The cell-wall is the membrane which separates the soil-water from the denser cell-sap. From the law of osmosis, we should expect a flow of liquids in both directions, the greater flow being into the cell-sap from the soil-water. It has been found, however, that the 
protoplasm permits the inward flow of the soil-water, but practically prevents the outward flow of the cell-sap. Thus we see that protoplasm has a selective action. Since the growing parts of roots have countless root-hairs, these cells of the epidermis together act like a great sponge which absorbs the large quantities of water and mineral matters which are needed by all plants. This liquid passes from one cell to another until it reaches the central cylinder. A study of the microscopical structure of the central cylinder makes evident the fact that this part of the root consists not only of tough wood cells as explained
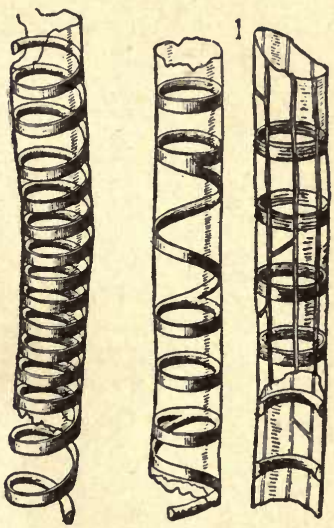

Frg. 14.-Ducts that convey the sap upward through the root, stems, and leaf. The walls of these ducts are strengthened by spiral fibers or rings. in the preceding section, but also of tubular cells called ducts. (See Fig. 14.) Through these ducts the sap is conveyed upward to the stem.

\section{The Structure and Adaptations of Stems}

59. The structure of a woody stem. - Laboratory Study No. 31 .

A. The structure of a young stem.

Secure pieces of a young stem of a horse-chestnut, maple, lilac, or other woody stem that shows the three layers of bark. Split some pieces lengthwise in halves.

1. Peel off the outer covering, the bark, from a piece of the stem till the wood is exposed. The bark of 
a young stem usually consists of three more or less distinct layers.

a. With a knife gently scrape off an outer or brown bark, and expose a dark green layer known as the green bark. Scrape this until you come to a more or less tough layer known as the fibrous bark or bast (which may be slightly green). Describe each of these barks as to position and color.

b. Pick into threads the fibrous bark; in what direction of the stem do the fibers run? By breaking strips of each layer determine which of the three barks is toughest.

2. Feel of the wood from which the bark has just been removed. Describe the substance which covers the wood, after scraping off a little with your thumb nail. This is the cambium or growing layer, which produces the new wood and bark. When the bark is torn off, the cells of this layer are broken and the slimy protoplasm oozes out.

3. By means of a penknife or pin dig into the wood and also into the pith at the center of the stem. Compare the wood and the pith as to relative position and hardness.

4. By the aid of compasses make a diagram, at least three inches in diameter, of the cross section of a woody stem to show the relative thickness of the various layers. (These layers might well be represented by different colors.) Label brown bark, green bark, fibrous bark or bast, cambium layer, wood, pith.

B. The structure of an older stem. (Optional.)

Cut some cross sections of stems several years old. (Admirable material can be obtained by sawing into pieces about two inches long white oak sticks three to four inches in diameter.) Each piece should then be split into halves and each surface planed and sandpapered. These pieces are valuable as permanent preparations. 
1. Which of the three regions (bark, wood, and pith) found in the young stem can you readily distinguish? Which of the three becomes very much thicker and harder as the stem grows older? Which is very small in quantity when compared with the young stem?

2. The curved layers of wood in the cross section are known as annual rings, so called because usually only one ring is formed each year by the cambium layer. How many years of growth are shown in the piece of wood you are studying?

3. The lines in the cross section extending like the spokes of a wheel are the pith rays or medullary rays. Describe the appearance of these rays. The shining, lighter colored surfaces (to which the beauty of "quartered oak" furniture is due), that appear in the longitudinal sections of oak wood, are the pith rays. Find pith rays in the middle surfaces of some of the oak pieces you are studying, and describe them.

4. Make a large diagram of the cross section of the piece of wood you are studying. Label bark, wood, annual rings, medullary or pith rays.

\section{The structure of the corn stem. - Laboratory Study No. 32. (Optional.)}

Cut pieces about two inches in length from full-grown corn stalks, and split each piece in halves. (If necessary these pieces may be preserved from year to year in 4 per cent formalin or in 70 per cent alcohol.)

Examine the cross and longitudinal sections of corn stem. Find the rind (the outer layer), the woody bundles or fibers (thread-like structures), and the pith (material between the bundles).

1. Thrust your pencil point into the pith; is this material hard or soft?

2. Pull out one of the woody fibers; is it tough or tender?

3. Push your pencil point into the rind; is it hard or soft?

4. Make a drawing $(\times 2)$ showing both cross and longitudinal surfaces. Label rind, woody bundles, pith. 
61. Experiments to show the upward path of sap through stems. - Laboratory Study No. 33.

$A$. Stand some live twigs (e.g. maple or horse-chestnut) in red ink for a day or two; cut off pieces above the level of the ink, and split some of these pieces in half lengthwise.

1. Describe the preparation of the experiment.

2. Through what part of the stem does the red ink rise?

3. What do you conclude, therefore, as to the part of a woody stem through which sap rises?

$B$. (Optional.) Stand in red ink some pieces of fresh corn stalk (or if this cannot be obtained, some Tradescantia or any lily stem). Cut some cross and longitudinal sections above the level of the ink.

1. Write an account of the experiment, stating your observations.

2. In the stem you are studying, is sap carried upward by the rind (epidermis in the lily), or by the pith, or by the woody fibers? How do you know?

62. Stems as organs for support and leaf exposure.When we studied the manufacture of carbohydrates by plants, we proved that green leaves must be exposed to sunlight in order to carry on this important function. When the leaves receive the proper amount of exposure, the food can be manufactured rapidly. Hence, we should expect to find that leaves are arranged in such a way as to secure the best amount of sunlight. Where plants are more or less crowded, as in forests or thickets, the main stems, such as the trunks of trees, usually grow tall, thus lifting the leaves to the light. The amount of light exposure of trees and of most other plants is largely increased by branches and their subdividing twigs, to which the leaves are attached.

In order that the trunk and its branches may be able to support the leaves and withstand the force of storms, thick- 
walled wood-cells are developed. Each wood-cell, when separated out from the rest, and examined with the high power of the compound microscope, is seen to be shaped somewhat like a tiny toothpick, and the thin ends of these cells fit together closely by overlapping. (See Fig. 15.)

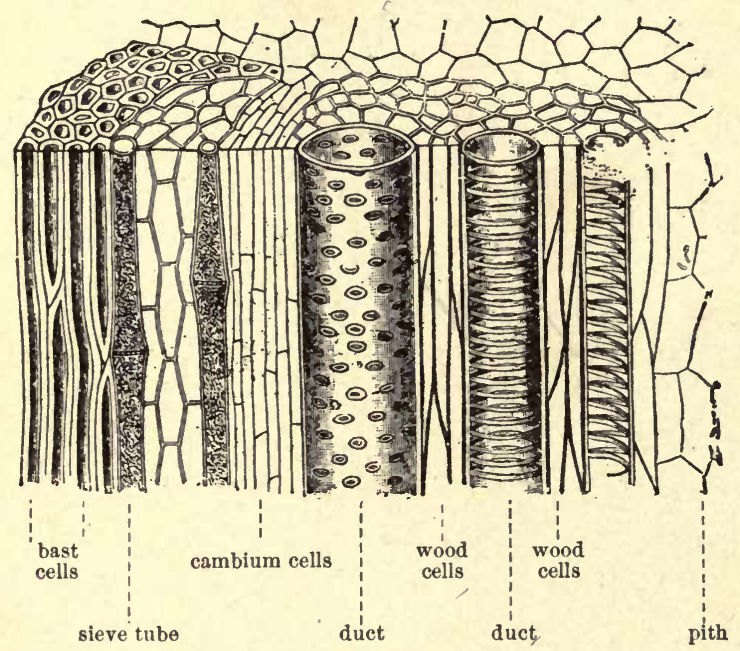

Fig. 15. - Woody bundle of sunflower stem.

Stems like the corn stalk and bamboo have most of their supporting material on the outside, and these stems are in the form of cylinders which are either hollow (as in grasses) or filled with pith through which pass the woody bundles (as in the corn stalk). It has been proved that when a given amount of material is arranged in the form of a hollow tube, it will withstand a much greater strain without breaking than when this material is in the form of a solid rod. This mechanical principle is made use of in the construction of the frame of a bicycle and of the pillars that support buildings.

63. Stems as organs for the transmission of sap. - Leaves not only require an abundance of sunlight, but they must 
also be supplied with water and other materials from the soil. Our experiment with red ink (see 61) showed that the soil-water is carried upward through the woody portions of stems. A microscopical examination of thin sections of a stem (see Fig. 15) shows the presence of tubular cells
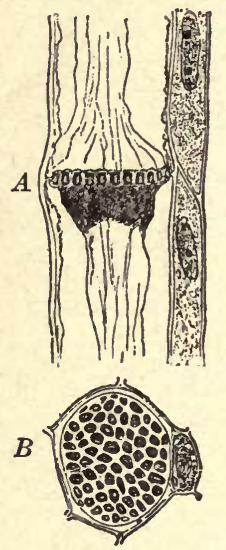

Fig. 16.- Sieve tube, that conveys sap downward through the leaf, stem, and root. $A$, longitudinal section showing edge view of sieve plate (in the middle) ; $B$, surface view of sieve plate.

known as ducts, similar to those found in the central cylinder of roots with which they are connected. These are the parts of the wood through which the soil-water passes most readily up to the leaves.

After the raw materials have been changed into the plant foods by green leaves, these plant foods, by the process of digestion, are changed into such a form that they can pass from the leaves into the fibrous bark in which are tubular cells known as sieve-tubes. (See Figs. 15 and 16.) Through these the liquid food passes down the stem to be stored away or used in the growth of root or stem. In young stems the pith rays or medullary rays $(\mathbf{5 9}, \mathrm{B}, 3)$, the fine lines extending from the bark toward the center of the stem, are supposed to serve as channels for the passage of food across the stem and also for the storage of food.

In the type of stem represented in the corn, lilies, and palm trees, the woody material through which sap passes is not arranged in the form of annual rings, but the woody bundles are scattered through the pith. Each bundle consists of ducts that carry the soil-water up through the stem out into the leaves, of sieve-tubes that convey downward from the leaves the manufac- 
tured food substances, and of wood cells that help to strengthen the bundle.

64. Changes in stems during their growth. - In our discussion thus far, we have considered the adaptations of stems for exposing leaves to the light and for transmitting food materials to and from the leaves. But the stem has other important functions which we are now to consider. In a young twig, before the brown bark thickens and shuts out the light, the green bark, on account of the presence of chlorophyll, is enabled to carry on the manufacture of carbohydrates. In a very young, stem the surface is covered by thin epidermis which helps to prevent the undue escape of moisture. In this layer are tiny openings that allow the inward and outward passage of gases that occur in breathing and food manufacture. Later this epidermis is replaced by the outer or brown bark, which serves as a means of protection against unfavorable weather conditions and insects. In this brown bark the tiny openings referred to above are developed into large openings known as lenticels which

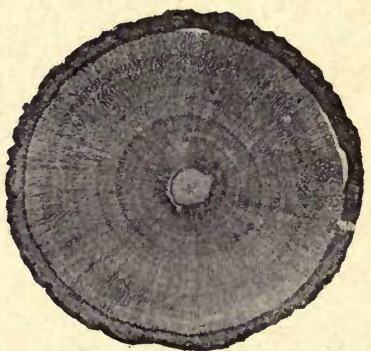

Frg. 17. - Cross section of a tree trunk showing bark, wood (with its annual rings and medullary rays), and pith at center. - (Courtesy of New York Botanical Garden.) carry on the same functions. In an old tree the outer bark becomes very thick and corky and the green layer disappears entirely.

The growth of the tree in thickness, as already stated, is due to the activity of a layer of cells between the wood and the fibrous bark. This is the cambium layer (Fig. 15). In early spring the cambium cells by rapid growth and division form on their innermost surface a new layer of wood (which appears 


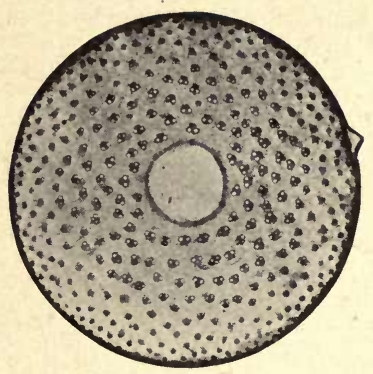

FIG. 18. - Cross section of young bamboo, showing hard outer rind, woody bundles, scattered through the pith. The center of the stem is hollow. - (Courtesy of New York Botanical Garden.) as a ring in cross section), and on their outer surface more fibrous bark. As the season advances, the activity of these cells becomes less and less, and finally growth ceases during the winter. ${ }^{1}$

Stems of plants like the corn, bamboo, and palm have no true cambium layer, and therefore even in the case of plants of this type that live on from year to year no annual rings are formed. In the growth of these stems, new bundles develop in the pith between those already formed.

\section{The Structure and Adaptations of Leaves}

65. Leaf arrangement. ${ }^{2}$ - Along the sides of twigs leaves are arranged in such a way as to secure as much light as possible without being shaded by the leaves above them. Thus in plants like the horse-chestnut, maple, and lilac, the leaves are arranged so that at a given level on the twig two leaves are opposite each other, while the next pair are at right angles to the first pair. This is known as an opposite arrangement. The beech, elm, and rose, on the other hand, have an alternate arrangement, only one leaf being found at a given level on the twig.

66. External structure of a horse-chestnut twig. - Laboratory Study No. 34. - (Optional.) (Maple, beech, or other woody twig may be used with slight verbal changes.)

${ }^{1}$ Sometimes trees form more than one ring during a season.

2 Before assigning this section for study, the teacher should demonstrate from leafy twigs (e.g. maple, horse-chestnut, lilac, elm, apple) the characteristic differences between the opposite and alternate arrangement of leaves. 
A. Leaf scars. (The horseshoe-shaped scars with the raised dots like horseshoe nails indicate the places where the stalks of the leaves were attached.)

1. Do the leaf scars occur in pairs, or is there only one scar at a given level? How, therefore, were the leaves arranged on the stem?

2. Count the number of dots on several differentleafscars; these dots are the ends of the wood bundles that carried sap to the various leaflets. Look at the picture of horse-chestnut leaves. (See Fig. 20, K.) How many main veins do you find in one compound leaf? Compare this

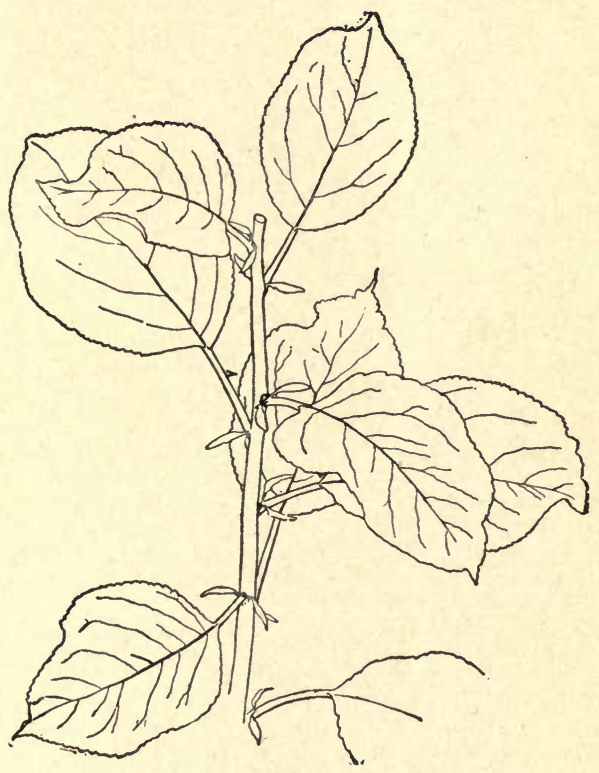

FIG. 19. - Spray of young apple tree, showing alternate arrangement. At the base of each leaf stalk is a pair of small stipules. - (Bailey.) number with the number of dots on the leaf scars; what do you conclude?

B. Buds. (At the end of most twigs is a single terminal bud; the buds along the side of the twig are lateral buds. Each bud is covered with bud-scales.)

1. State the position of each kind of bud on the twig. Where are the lateral buds found with reference to the leaf scars? 

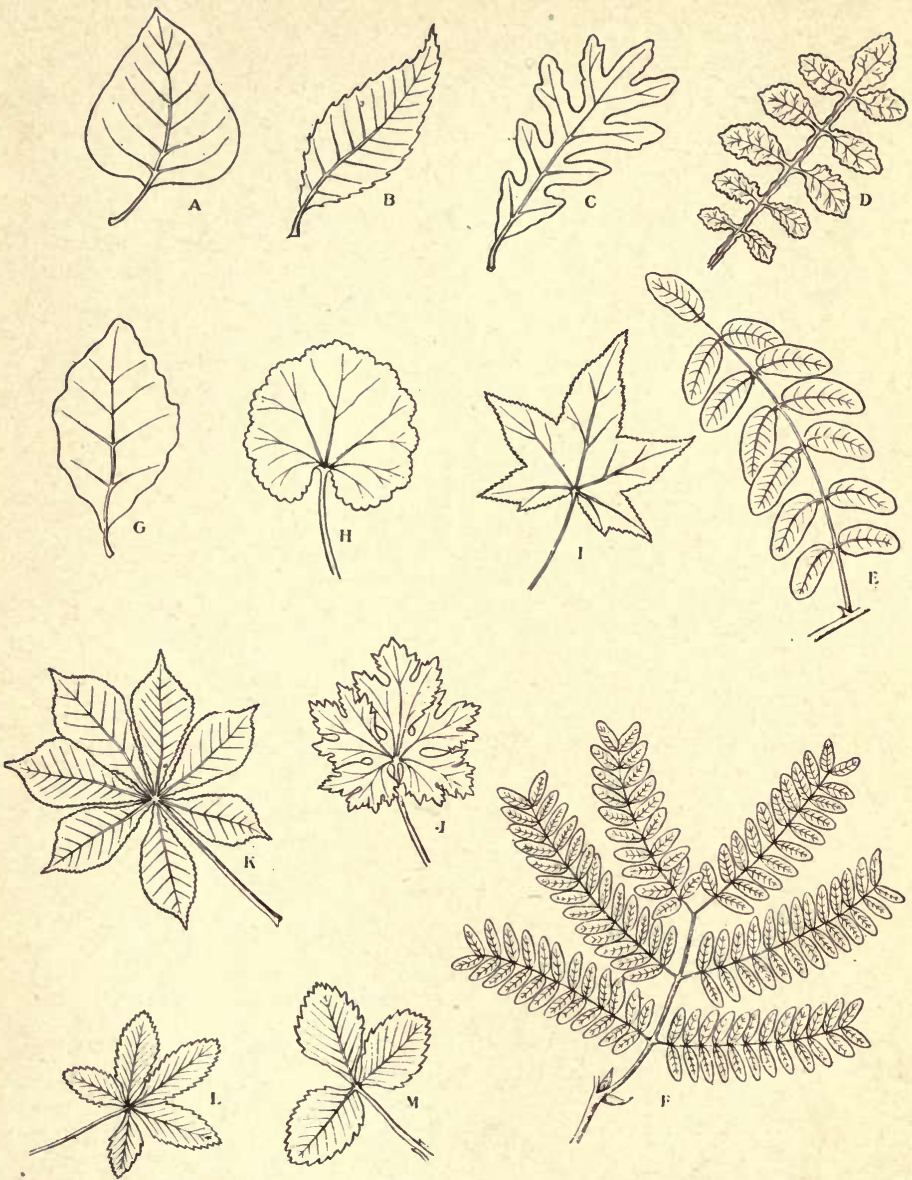

FIg. 20. - Forms of leaves. - (Courtesy of Furman and Miller, Botanical Aid, Western Publishing Co., Chicago, Ill.)

Simple leaves
$A$, lilac;
$C$, white oak ;
$G$, oak;
$B$, chestnut ;
$D$, celandine;
$H$, geranium;
I, sweet gum;
$J$, buttercup;
Compound leaves
$E$, locust;
$L$, cinquefoil ;
$F$, wild tamarind
$K$, horse-chestnut ;
$M$, wild strawberry ;
(twice compound). 
2. Look carefully at the scales of the terminal bud to see if they have any definite arrangement. State whether or not this arrangement corresponds to that of the leaf scars.

3. (Demonstration.) Examine a terminal bud from which one or two scales have been removed. Bud-scales are modified leaves. How do these scales differ from ordinary leaves? What is the use of the scales to the bud? How are they adapted for this use?

C. Bud-scale scars. (These are also called annual scars because they are formed at the beginning of the growing season of each year when the terminal bud opens and its scales fall off. To prove this, remove one or two outside scales from a terminal bud, and note the scar thus formed.)

1. How many groups of bud-scale scars or annual scars do you find on the twig you are studying?

-2. Since one set is formed each spring, how many years of growth are shown on the twig?

D. Breathing pores or lenticels. Look for small elevations on the bark. These locate the lenticels. Describe the lenticels.

$E$. Make a careful outline drawing of the twig, showing its form, the position and shape of the leaf scars with their woody bundles, the terminal and lateral buds, bud-scales, budscale scars, and lenticels. Label each of the structures shown in your drawing.

67. The structure of leaves. - Laboratory Study No. 35. A. Parts of a leaf.

1. Examine a simple leaf, e.g. maple, geranium, or lilac, and note that it is made up of the following parts: a leaf-stalk, which attaches the main part of the leaf to the stem of the plant, and the blade, the flat, expanded portion.

$a$. How does the blade differ in form from the leafstalk?

$b$. Hold the leaf to the light. How many main veins do you find? Where are they smallest? By what are the main veins connected? 
c. Make a drawing, natural size, by tracing the outline of the leaf-stalk and blade. Draw carefully the principal veins and a few of their branches, being careful to show their relative size and their connections. Label leaf-stalk, blade, main veins, network of veins.

2. (Optional.) Examine a compound leaf, e.g. rose, clover, locust, pea, horse-chestnut. Notice that the blade is divided into three or more parts known as leaflets, which are attached either to the end of the leafstalk or on either side of the mid-vein of the compound leaf.

$a$. In what respect, therefore, does the blade of a compound leaf differ from the blade of a simple leaf?

$b$. Compare the arrangement of the leaflets in a leaf like the rose, locust, or pea with that in the Virginia creeper or horse-chestnut. Which leaves have the leaflets arranged like the bones in the palm of the hand (palmately compound), and which have the leaflets arranged along the side of the mid-vein as in a feather (pinnately compound, from Latin, pinna $=$ feather)?

c. At the base of the leaf-stalk of the rose, clover, or pea leaf, notice two leaf-like objects (small in the case of the rose). These are known as stipules. Stipules are also found as a part of many simple leaves. How do stipules differ from the other parts of leaves? (See Fig. 19.)

B. Gross structure of leaves. - Secure thick leaves such as sedum, tulip, hyacinth, or onion.

1. Peel off from the upper and lower surface a thin membrane known as the epidermis. Hold the epidermis between yourself and the light. Tell what you have done and state two characteristics of epidermis. 
2. Examine the material left after removing the epidermis, scraping it with a knife. This inner region of the leaf is known as mesophyll (Greek, meso $=$ middle + phullon $=$ leaf $).$ Describe the mesophyll, stating how it differs from the epidermis.

3. Look carefully for veins in the mesophyll. Describe their appearance.

4. (Optional.) Make a diagram at least half an inch in thickness of a small portion of the cross section of the leaf you are studying, labeling upper epidermis, mesophyll, veins, and lower epidermis.

C. Microscopical structure of leaves. - Demonstration.

1. Strip off a piece of epidermis from one of the thick leaves named in $B$ above; lay it on a glass slide, add a drop of water, and cover with a cover glass. Examine with the low power of the compound microscope, comparing the specimen with Fig. 21. Notice the shape of the cells of which the

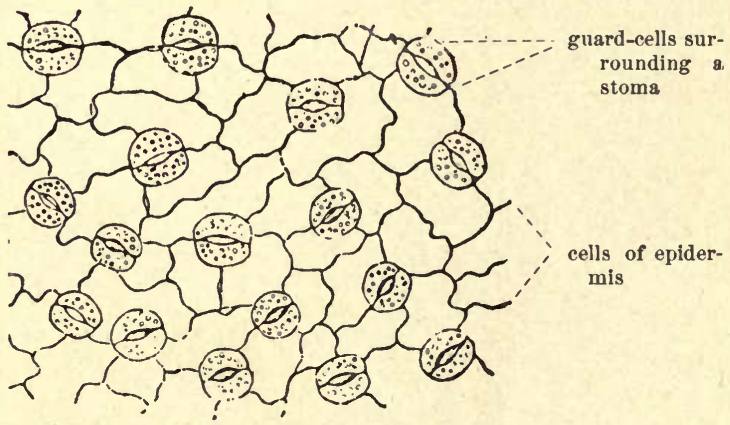

Frg. 21.-Lower epidermis of a leaf.- (Strasburger.)

epidermis (shown by the faint outlines of their walls) is composed. Find little oval bodies scattered among the cells of the epidermis, each hav- 
ing an opening in the middle. This opening is called a stoma, plural stomata (Greek, stoma $=$ mouth). Each stoma is surrounded by two guard-cells.

Make a diagram, greatly enlarged, of a stoma with its guard-cells, together with the cells of the epidermis that immediately surround it. Label cells of the epidermis, guard-cells, stoma.

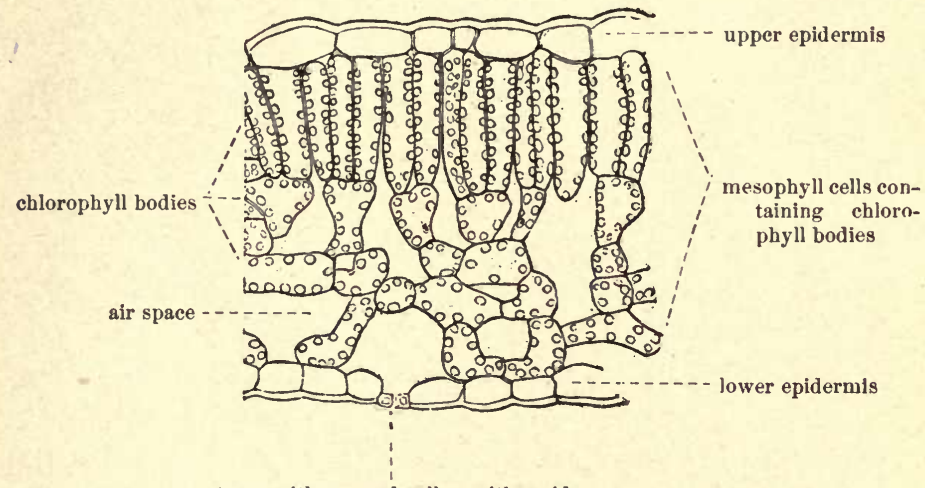

stoma with a guard-cell on either side

Fig. 22. - Cross section of a leaf. - (Strasburger.)

2. Study Fig. 22 and make out the shape and location of each of the following parts of which it is composed: upper epidermis, mesophyll cells, chlorophyll bodies, air spaces between the cells, lower epidermis, stoma. In your note-book make a drawing considerably enlarged showing a small portion of the cross section, and label each part.

68. Experiment to demonstrate the path of sap through leaves. - Laboratory Study No. 36.

Place in red ink the lower end of a leafy branch of any vigorous plant, e.g. geranium or bean seedling, and allow 
it to stand in sunlight or a warm place until the red color appears in the leaves.

1. Give an account of the experiment, stating your observations.

2. What do you conclude as to the part of the leaf through which soil-water is distributed to different parts of the blade?

3. What cells of the root did you find specially adapted for absorbing water from the soil? Through what regions of the root and stem is sap carried up to the leaves?

69. Is water vapor given off by the leaves of a green plant?

- Laboratory Study No. 37. Demonstration.

1. Wrap sheet rubber or thin oilcloth about a pot containing a vigorous plant which has been thoroughly watered. Tie the rubber or oilcloth tightly about the stem to prevent the escape of water from the soil. If rubber tissue cannot be obtained, melted paraffin may be poured over the soil, and the pot painted with hot paraffin. Cover the plant thus prepared with a large bell jar with the inner surface dry, and stand it in the sun for a few hours.

a. Describe the preparation of the experiment, stating the reason for using the rubber or paraffin.

$b$. State your observations and conclusion.

c. Why is the bell jar necessary?

$d$. What becomes of the water vapor given off by the leaves of trees?

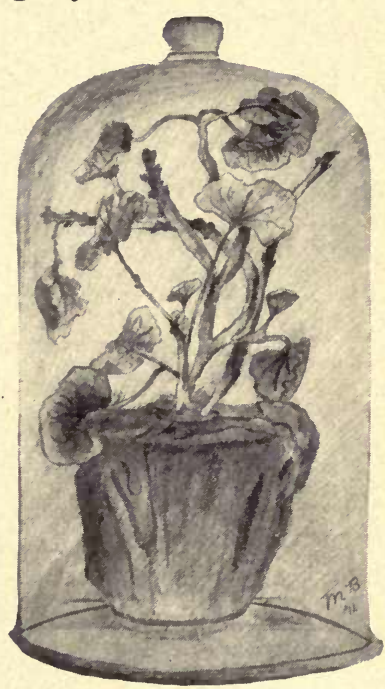

Frg. 23. - Apparatus to show the excretion of water from a plant. 
2. (Optional.) Put the plant prepared as above on one of the scale pans of a balance and with it a stoppered graduate or a stoppered bottle. On the other pan put weights enough to equalize the balance. At the end of 24 hours put enough water into the graduate or bottle to cause the weights on the two pans to be equal.

$a$. Describe the preparation of the experiment.

$b$. What volume of water was necessary to equalize the weights (i.e. how much water was given off from the plant in 24 hours) ?

c. In a similar way add water each 24 hours for a week or until the plant shows signs of wilting. What is the total amount of water given off during the experiment?

$d$. Bearing in mind the relative amount of leaf surface of this plant and on the trees of a forest of even a few acres, what would you infer as to the quantity of water given off by the trees of a forest during a summer season?

70. Leaves as organs for food manufacture. - While studying the manufacture by plants of carbohydrates (sugar and starch) we showed that the raw materials necessary for this process are water and carbon dioxid. We have proved that water enters the root-hairs by osmosis and travels in a system of ducts through the woody portion of roots and stems out to the leaves. Here the ducts of the stems connect with a network of veins containing similar ducts by means of which the soil-water is supplied to the cells that are to manufacture the food. The carbon dioxid that is needed is secured from the air. This gas passes through the openings (stomata) in the epidermis, and enters the air spaces in the mesophyll, and finally reaches the cells containing the chlorophyll bodies.

The sunlight acting upon the chlorophyll bodies enables them to combine the elements found in the water and carbon dioxid to form carbohydrates. These, as we have seen, are 
probably used in the manufacture of proteins. In the leaves, as elsewhere in the plant, the various foods are digested and thus are prepared to be carried by the tubular cells (sieve tubes) in the veins and down through similar tubular cells in the fibrous bark. (Fig. 16.)

71. Excretion of the by-products of food manufacture. We showed in 35 that during the process of carbohydrate manufacture oxygen is set free, and this gas is given off through the stomata into the air. Water, too, is a by-product of food manufacture and assimilation. In the manufacture of proteins mineral matters are necessary, and these are carried up the stem dissolved in the soil-water. Since, however, the soil-water is such a dilute solution, great quantities of this liquid must be supplied; hence, much more water is taken in than is needed for food manufacture or making of protoplasm. This excess of water is given off in large quantity by the leaves of green plants (see 69).

The amount of water thus excreted by leaves is regulated more or less by the action of the guard-cells that surround each stoma. When the plant is well supplied with water, the stoma remains wide open. If, on the other hand, the leaves lack a sufficiency of water, these guard-cells close in upon the stoma, and so prevent undue loss of moisture. In plants having leaves in a horizontal position, the stomata are mostly located on the lower surface, the upper surface, which is more exposed to the sunlight, being covered with a continuous layer of epidermal cells. Were the epidermis altogether absent from leaves, the mesophyll cells would soon lose so much water that they would die.

72. Storage of foods in plants. - The foods that are manufactured in the chlorophyll-bearing cells may be carried, as we have seen, to other parts of the plant, there to be 
stored until needed. Whenever large amounts of starch, sugar, protein, or fat are thus stored, the organs containing these substances frequently become enlarged (e.g. carrot (Fig. 81), potato (Figs. 49,60), and onion) and the walls of the cells in these organs usually remain thin and soft, permitting the inward and outward passage of food. (See Fig. 9.)

73. Summary of functions of the parts of the nutritive organs of green plants.

\begin{tabular}{|c|c|c|}
\hline NAME of PART & Where Part is Found & $\begin{array}{l}\text { Principal Function or Functions } \\
\text { of Parts }\end{array}$ \\
\hline Epidermis & Covering of root & $\begin{array}{l}\text { Absorbs soil-water, largely } \\
\text { through root-hairs }\end{array}$ \\
\hline Epidermis & $\begin{array}{l}\text { Covering of stem } \\
\text { and leaves }\end{array}$ & $\begin{array}{l}\text { Protects inner layers, pre- } \\
\text { vents undue escape of } \\
\text { moisture }\end{array}$ \\
\hline Lenticels & $\begin{array}{r}\text { Brown bark of } \\
\text { stem }\end{array}$ & $\begin{array}{c}\text { Permit entrance of } \mathrm{O} \text { and } \mathrm{CO}_{2} \\
\text { and escape of } \mathrm{O} \text { and } \mathrm{CO}_{2}\end{array}$ \\
\hline Stomata & $\begin{array}{c}\text { Epidermis of } \\
\text { leaves }\end{array}$ & $\begin{array}{c}\text { Permit entrance of } \mathrm{O} \text { and } \mathrm{CO}_{2} \\
\text { and escape of } \mathrm{O} \text { and } \mathrm{CO}_{2}\end{array}$ \\
\hline Guard-cells & Surround stomata & Regulate escape of $\mathrm{H}_{2} \mathrm{O}$ \\
\hline Air spaces & $\begin{array}{l}\text { Between meso- } \\
\text { phyll cells }\end{array}$ & $\begin{array}{l}\text { Serve as reservoirs of } \mathrm{O} \text { and } \\
\mathrm{CO}_{2} \text { and water vapor }\end{array}$ \\
\hline $\begin{array}{l}\text { Chlorophyll- } \\
\text { bearing cells }\end{array}$ & $\begin{array}{c}\text { Mesophyll of } \\
\text { leaves, green } \\
\text { bark of stem }\end{array}$ & Manufacture carbohydrates \\
\hline Ducts & $\begin{array}{l}\text { Central cylinder of } \\
\text { root, woody part } \\
\text { of stem, veins of } \\
\text { leaves }\end{array}$ & $\begin{array}{l}\text { Transport soil-water upward } \\
\text { through the plant }\end{array}$ \\
\hline Sieve tubes & $\begin{array}{l}\text { Fibrous bark of } \\
\text { stem, veins of } \\
\text { leaves }\end{array}$ & $\begin{array}{l}\text { Transport digested foods } \\
\text { downward through plants }\end{array}$ \\
\hline
\end{tabular}




\begin{tabular}{|c|c|c|}
\hline NAME of PART & Where Part is Found & $\begin{array}{l}\text { Principal Function or Fenctions } \\
\text { of Parts }\end{array}$ \\
\hline Wood cells & $\begin{array}{l}\text { Central cylinder of } \\
\text { root, woody part } \\
\text { of stem, veins of } \\
\text { leaves }\end{array}$ & $\begin{array}{l}\text { Resist forces tending to break } \\
\text { roots, stems, or leaves }\end{array}$ \\
\hline Cambium layer & $\begin{array}{l}\text { Between bark and } \\
\text { wood of stem }\end{array}$ & $\begin{array}{l}\text { Provides for growth of wood } \\
\text { and fibrous bark or bast }\end{array}$ \\
\hline Pith & Interior of stem & Stores food \\
\hline Pith-rays & $\begin{array}{l}\text { Woody layer of } \\
\text { stem }\end{array}$ & $\begin{array}{l}\text { Transfer food across stem, } \\
\text { and store food }\end{array}$ \\
\hline
\end{tabular}




\section{CHAPTER VI}

\section{RESPIRATION AND THE PRODUCTION OF ENERGY IN PLANTS}

\section{The Storage and Liberation of Energy}

74. Examples of energy in plants. - By energy we mean the capacity to do work. In the preceding chapters we have considered to some extent the structure of various parts of plants and some of the functions which they are fitted to perform. Now to carry on most of these functions requires the expenditure of energy on the part of the plant. Thus, for example, roots in growing expend considerable energy, pushing their way through the soil. Stems in like manner exert energy in lifting to the light and air their weight of branches and leaves. We know, too, that soil-water is carried up through plants to considerable heights (several hundred feet in very large trees), that substances obtained from the soil and air are digested and transported from one part of a plant to another. Still another form of energy exhibited to a certain degree by plants is heat, as the following experiment will show.

75. To prove that heat energy is developed in growing seedlings. - Laboratory Study No. 38.

Secure two wide-mouthed bottles of the same size (lightning fruit jars will answer) and put some wet blotting paper in the bottom of each. Fill one of the jars half full of sprouting peas. Fill the other jar half full of peas that have been killed by being soaked in a 5 per cent solution of formalin for 
twenty-four hours. Rinse the seeds with boiled water to remove the preserving fluid. Get two thermometers that have approximately the same temperature reading in the air of the laboratory. ${ }^{1}$ Push the lower end of the thermometer down among the sprouting seeds so that the mercury will be covered by the seeds. Do the same with the second thermometer in the jar of dead seeds. Set the jars side by side in a warm place for twenty-four hours or more.

1. Describe the preparation of this experiment. In what respects are the conditions the same in both jars? In what one respect do the two jars differ?

2. Take the temperature readings of the thermometer in each of the two jars and record results. What difference do you notice in the temperature of the seeds in the two jars?

3. What is your conclusion from the experiment as to the development of heat energy in seedlings?

76. Energy and its transformations. - We see from the preceding discussion and experiment that plants exhibit considerable energy or ability to do work. Animals and man, however, show far more striking proofs of the output of energy in their muscular movements, for example, in running, swimming, and flying. Various machines, also, enable us to make use of different forms of energy, and, as we shall now see, one kind of energy may be readily transformed into another by means of these machines. Suppose we consider the work that goes on in an electric power plant. The coal that is shoveled into the fire-box beneath the boilers by the process of oxidation liberates heat, which is one of the forms of energy. The heat changes the water into steam, which expands and so exerts its power to run the engine, and thus heat energy is transformed into the energy of motion. When the engine is connected with a dynamo, this energy of mo-

${ }^{1}$ If a difference in the reading of the two thermometers is evident, this difference should be computed in the later readings on the thermometers. 
tion is changed into electrical energy, and this in turn may be converted into light or heat energy in our houses or into energy of motion, as, for instance, in the running of a trolley car.

77. Source of the energy developed in living things. In all these marvelous transformations of energy that we have just enumerated no new energy is created and none is destroyed. Whence, then, comes this abundant supply of energy? We shall find the probable answer to this question in considering again the processes carried on in the leaves of plants. From the sun comes the radiant energy that is absolutely essential for the activity of the chlorophyll bodies, by which carbohydrates are formed. In the formation of these compounds, the sun's radiant energy is used and apparently disappears. ${ }^{1}$ In reality, however, it has only been stored in the chemical compounds formed thereby, since, as we have said above, energy cannot be destroyed.

78. Oxidation as a means of liberating energy. - Let us now refer once more to the processes that take place in an electric power plant. We have just said that the energy derived from the rays of the sun is stored up in the wood, coal, and other fuel. In order to set free from these compounds the energy they contain, the wood or coal must be burned, or in other words combined with oxygen. Every one knows that when we wish to secure a large amount of heat from our fuel we open wide the drafts in order to secure a plentiful supply of oxygen. We demonstrated in our studies in oxidation that whenever a substance is burned, heat energy is liberated

1 The authors are indebted to Mr. Paul B. Mann of the Morris High School Department of Biology for the following demonstration of the effectiveness of the radiant energy of the sun. Place a radiometer (usually found in the physies equipment of schools) in direct sunlight, and then remove it from the sun's rays. Try also the effect of an electric light by bringing the radiometer near the light bulb, and then slowly removing it to a distance. 
and usually light is seen. The energy set free by the oxidation of fuel may be transformed at one time into light, at another time into motion, or again into heat.

It is probably true that the liberation of energy in living plants is somehow due to the action of oxygen. The process, however, is doubtless extremely complicated, and just what takes place no one knows. Certainly oxygen in some form is essential for the life of every plant and animal. That this is true of plants, the following experiment will show.

79. To prove that seeds need air in order to grow. Laboratory Study No. 39. Demonstration or Home Work.

Secure two wide-mouthed bottles and place in the bottom of each a wet sponge or some wet blotting paper, and pour enough water in each bottle just to cover the sponge or paper. Fill both bottles with pea seeds that have been soaked in water for twenty-four hours. Insert a tightly fitting cork into the mouth of one of the bottles to exclude the air. Leave the other bottle open to the air, and add enough water from day to day to make up for the loss by evaporation. Put both bottles in a warm place.

1. Describe this experiment, showing in what respects the conditions are the same for both groups of seeds.

2. In what one respect do the two groups of seeds differ?

3. At the end of several days examine both bottles of seeds, and state your observation concerning the amount of growth in each bottle.

4. State clearly your conclusion as to the necessity of air for growth of pea seedlings.

80. Relation of oxygen and carbon dioxid to oxidation. We have now demonstrated that seedlings will not grow without air. Biologists have proved conclusively that oxygen is the element in the air that is essential for the work of all plants, and that without it they die. Hence, we may conclude, as in the case of the furnace, that the necessary energy 
of a plant is in some way set free by oxygen acting upon plant compounds. When oxidation of compounds containing carbon takes place, we find that carbon dioxid is produced (11). Now if processes like oxidation are carried on in plants, we should expect to find that $\mathrm{CO}_{2}$ is formed. The following experiment proves clearly that such is the case.

81. To prove that carbon dioxid is formed during the growth of young seedlings. - Laboratory Study No. 40.

In the bottom of two large jars, (fruit jars will answer) place some wet blotting paper. Fill one of the jars half full of germinating peas, and place a small wide-mouthed bottle full of lime water on top of the seeds. Screw the top of the jar on tightly. In the other jar place a bottle of lime water and cover as in the previous jar. At the end of twenty-four hours or more examine the lime water in both jars.

1. Describe the preparation of the experiment.

2. Compare the condition of the lime water in both jars. What has caused the change in the lime water in both jars?

3. Air, as we proved, contains a little carbon dioxid. Bearing this fact in mind, account for the difference in the appearance of the lime water in the two jars.

4. What gas, therefore, do you find to be given off during the growth of young seedlings?

\section{Respiration}

82. Respiration in plants. - It should be clear from our study thus far that all plants require oxygen, and that this oxygen brings about in plants a process resembling oxidation at least in the releasing of heat and other forms of energy and in the producing of carbon dioxid. These various processes take place in each living plant cell. Hence, every cell uses oxygen and must necessarily form carbon dioxid. This process which goes on in every living cell is respiration. 
In green plants during the night, when carbon dioxid is not being used for starch manufacture, this gas is given off to the surrounding air, which probably is not true to any great extent during the daytime. The taking in of oxygen and the giving off of carbon dioxid by plants corresponds to breathing in animals. This exchange of gases is carried on through the thin walls of roots, through the lenticels of stems, and through the stomata of leaves. The process of breathing must not be confused with that' of carbohydrate manufacture, and the following outline will show the fundamental difference between the two.

\begin{tabular}{|c|c|c|}
\hline & $\begin{array}{c}\text { CaRbohydrate MaNe- } \\
\text { FACTURE }\end{array}$ & $\begin{array}{l}\text { REspiration (INCLUdiNG } \\
\text { Oxidation) }\end{array}$ \\
\hline Where carried on & $\begin{array}{l}\text { In cells containing } \\
\text { chlorophyll }\end{array}$ & In all living cells \\
\hline When carried on & In sunlight & $\begin{array}{l}\text { Throughout life of } \\
\text { cell }\end{array}$ \\
\hline $\begin{array}{l}\text { Substances taken from } \\
\text { air }\end{array}$ & $\mathrm{CO}_{2}$ & 0 \\
\hline $\begin{array}{l}\text { Substance formed in } \\
\text { plant }\end{array}$ & Carbohydrates & $\mathrm{CO}_{2}$ \\
\hline $\begin{array}{l}\text { Waste substance ex- } \\
\text { creted to air }\end{array}$ & 0 & $\mathrm{CO}_{2}$ \\
\hline Advantage to plant & Manufacture of food & Release of energy \\
\hline
\end{tabular}




\section{CHAPTER VII}

\section{REPRODUCTION IN PLANTS}

\section{The Structure and Functions of Flowers}

83. Necessity of plant reproduction. - Every one knows that plants like peas, beans, and corn live but one year. Shrubs and trees, while they often live for many years, finally die. This is true of all plants. It is evident, therefore, that unless there were some means of producing new plants to take the place of those now living, all forms of plant life would soon cease to exist. The process by which new plants are formed is known as reproduction. In the higher plants this process is carried on by flowers, the function of which is to produce seeds which will develop into new plants. We are now to study the various parts of flowers and to consider the work of each part in this process of reproduction.

84. Study of tulip flower (spring study). - Laboratory Study No. 41.

Material: While the trillium is a more satisfactory flower for beginning the study of the process of reproduction, the danger that the wild flowers will become exterminated seems to make the study of the tulip advisable, especially in large city high schools. The two flowers, however, are usually in season at the same time, and if possible at least a few of the trilliums should be secured for demonstration. If this is impossible, the distinction between calyx and corolla should be taught from the apple blossom or other common flower. 
A. Floral envelopes. - Most flowers have parts shaped more or less like leaves which have either green or bright colors. These parts are arranged in one or more circles and make up the floral envelopes.

1. How many parts are there in the floral envelopes of a tulip? State the color or colors of these parts in the flower you are studying.

2. When there are two circles to the floral envelopes, an outer composed of green parts and an inner made up of brightly colored parts (as in the trillium or the apple blossom), distinct names are given to the various parts. The outer circle is called the calyx and its parts are known as sepals; the inner circle is called the corolla and each of its parts is called a petal.

a. State the number and color of the sepals in the calyx of the trillium.

b. How many petals do you find in the corolla? Describe their color.

3. Draw a side view of a tulip before it has fully opened. Label flower-stalk and floral envelopes.

B. Essential organs. - In the central part of the flower are the organs without which the work of the flower cannot be performed. For this reason they are called the essential organs.

1. The organs arranged in a circle just within the floral envelopes are known as stamens. State the situation and the number of stamens in the tulip. What is the number of stamens in the trillium or apple blossom?

2. Each stamen consists of a stalk called the filament and an enlarged part known as the anther. Name and describe each of the parts of a stamen.

3. Make a drawing twice its natural size of one of the stamens. Label filament, anther.

4. Find a flower the stamens of which have a powdery substance known as pollen. Which part of the stamen produces the pollen?

5. The organ at the center of the flower is called the pistil. It consists of three divisions at the top 
which together are known as the stigma, and the remainder of the pistil known as the ovary. Describe the pistil of the tulip (and of the trillium) as to position, shape, and color of its parts.

6. Make a drawing twice its natural size of the pistil. Label stigma, ovary.

7. Cut thin cross sections of a well-developed ovary, lay them on a dark-colored background, and study one or more of them with a magnifier to make out the following parts: wall of the ovary, small objects within the ovary known as ovules. (These ovules develop into seeds.) Describe what you have done and tell what you have seen.

8. Make a drawing at least an inch in diameter of a cross section of the ovary, labeling ovary wall and ovules.

9. (Optional.) Make a drawing (corresponding in size to that called for in 6 above) of a lengthwise section of the ovary to show wall of ovary, ovules. Label.

85. Study of the gladiolus flower (autumn study). Laboratory Study No. 42.

Note to the teacher. - Be careful to remove each flower close to the central stalk, so that the ovary may not be injured.

A. Parts of the flower.

1. Remove the two leaves at the base of the flower, since these leaf-like organs do not belong to the flower. The outer brightly colored parts of the flower are called the floral envelopes. These colored parts unite to form a greenish tube below.

$a$. Count and record the number of divisions of which the floral envelopes are composed.

$b$. State whether or not these divisions are all of the same size.

2. The slender stalks with purple tips, inside the floral envelopes, are called stamens. How many stamens do you find? 
3. The single white stalk with three divisions at the top is the upper part of the pistil. The dark green body below the tubular part of the floral envelopes is the lower part of the pistil.

Is the top of the pistil in the flower you are studying lower or higher than the stamens?

4. Make a drawing, natural size, of the side view of the flower, and label the following parts: the divided portion of the floral envelopes, the tubular portion of the floral envelopes, the stamens, the pistil.

B. Essential organs. - The stamens and pistils are called the essential organs of flowers because without them the work of the flower cannot be performed. 1. Carefully slit open the tubular part of the floral envelopes down to the lower part of the pistil. Then remove the floral envelopes, leaving the entire pistil uninjured.

a. State what you have done.

b. To what are the stamens attached?

c. The enlarged part at the top of the stamen is called the anther, the stalk-like part is called the filament. Name and describe the parts of a stamen.

2. Make a drawing, natural size, of a portion of the floral envelope to which a stamen is attached. Label division of floral envelopes, anther, filament.

3. Find a flower the stamens of which have a powdery substance known as pollen. Which part of the stamen produces the pollen?

4. The pistil consists of an enlarged portion at the base called the ovary, a stalk-like portion called the style, and a spreading portion at the top, each part of which is called a stigma. Name and describe each part of the pistil.

5. Make a drawing, natural size, of the pistil and label ovary, style, stigmas.

6. Cut thin cross sections of a well-developed ovary, lay them on a dark-colored background, and study one or more of them with a magnifier to make 
out the following parts: wall of ovary, small objects within the ovary known as ovules. These ovules develop into seeds. Describe what you have done and tell what you have seen.

7. Make a drawing at least an inch in diameter of a cross section of the ovary, labeling ovary wall, ovules.

8. (Optional.) Make a drawing (corresponding in size to that called for in 7 above) of a lengthwise section of the ovary to show wall of ovary, ovules. - Label.

86. Pollination. - We have learned in our study of flowers that pollen is produced in the anther of the stamen, and ovules

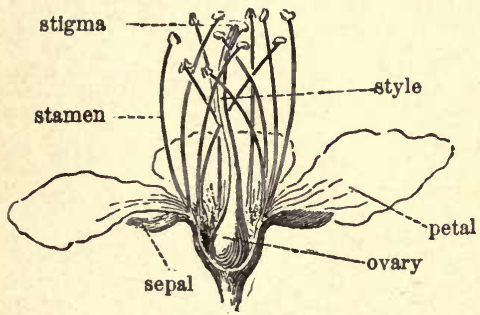

Fig. 24. - Structure of a plum blossom. (Bailey.) in the ovary of the pistil. Before an ovule can develop into a seed, however, certain portions of a pollen grain and of an ovule must be combined. Pollen must, therefore, be transferred from the anthers to the pistils, and to this process is given the name pol-

lination. We shall now learn by experiment some adaptations of the pistil for receiving and holding the pollen.

87. Experiment to show pollination. - Laboratory Study No. 43.

Rub a small brush or the end of a toothpick over a stamen (e.g. tulip, Easter lily, or gladiolus) which has an abundance of pollen, and then brush this pollen over the surface of the stigma.

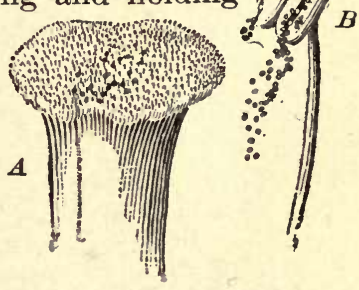

FIG. 25. - $A$, pollen adhering to stigma ; $B$, pollen of plum escaping from the anther of a stamen. - (Bailey.) 
1. Describe what you have done.

2. Examine the surface of the stigma with a magnifier and state what causes the pollen to stick to the stigma.

88. Microscopical Demonstration of Pollen Grains and their Development. - Laboratory Study No. 44. (Optional.) Prepare some sugar solution by adding to ten teaspoonfuls of water one teaspoonful of molasses or grape sugar and heat to boiling point. Put some of this sugar solution in a clean Syracuse watch glass. When the solution has cooled, ${ }^{2}$ mix with it some pollen from the flower of a tulip, a trillium, a sweet pea, or nasturtium. Several of these glasses might well be prepared with slightly different strengths of sugar solution and piled one above the other to keep out mold spores. $?$ Leave the glasses until the pollen grains have germinated. Study the preparation with the low power of the compound microscope.

1. Find some pollen grains that have not begun to grow tubes. Describe the form of one of the pollen grains.

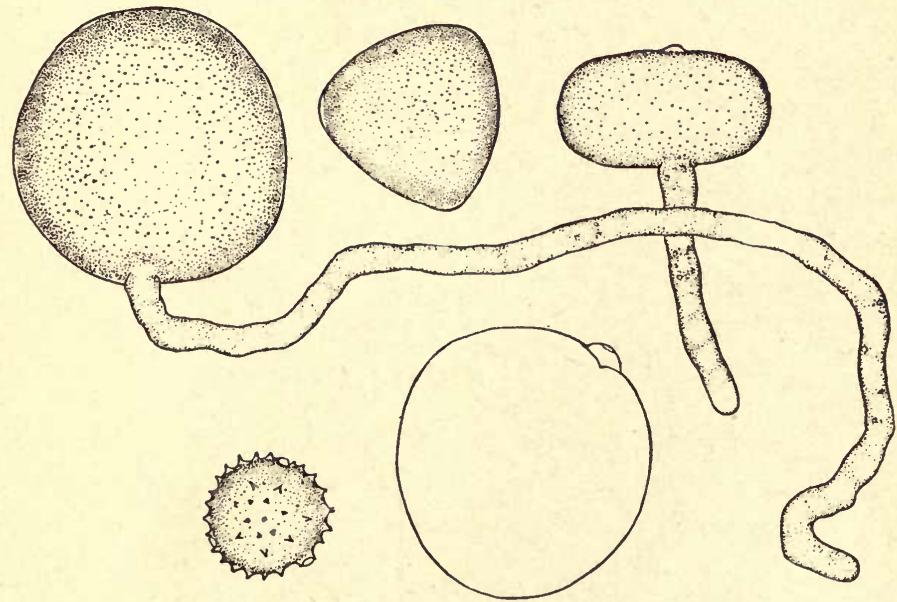

FIg. 26. - Different kinds of pollen grains, highly magnified, two of them forming pollen tubes. - (Duggar.) 
2. Find several grains that have formed tubes. What is the color and shape of the tubes?

3. Make a drawing at least a half inch in diameter of a pollen grain before it has sprouted and a drawing of another grain that has sprouted. Label pollen grain, pollen tube.

89. Pollination, germination of pollen grains, and fertilization. - We have now learned that pollen by the process of pollination is carried to the stigma of the pistil and adheres to the stigma by a sticky substance which is easily seen on the stigma of the Easter lily and often by hairs, also, as is the case in the tulip and gladiolus. It has been proved that this sticky substance contains sugar which together with other materials furnishes food for the growth of pollen tubes (see 88). As each tube forms, it makes its way down through the stigma and style (if present), and finally reaches an ovule in the ovary. The tip of the tube now penetrates an opening called the micropyle (Greek, micro $=$ small $+p u l a=$ gateway)

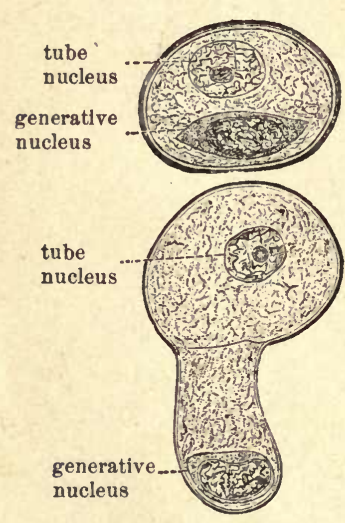

Fic. 27. - Pollen grain of lily and the development of the pollen tube, highly magnified. - (After Strasburger.) in the ovule. Part of the living substance of the pollen grain now unites with a part of the living substance of the ovule. This union is known as fertilization. After fertilization has taken place the ovule develops into a seed.

90. The cellular nature of pollen and ovules. - (If flowers are studied in the autumn, it is suggested that this Section 
be omitted until after the cellular structure of plants has been considered.) When the pollen grains are first formed in the anther, each consists of a single cell. Later the nucleus of this cell divides and forms two nuclei, one of which is the generative nucleus. The generative nucleus then divides and forms two sperm nuclei. The ovule is more complex in its structure, being composed of many cells of different kinds. But here, as is the case with the pollen grain, there is one important cell that is essential in the process of reproduction, and this is known as the egg-cell (Figs. 27 and 29, A).

91. The formation of an embryo. - When the pollen grain germinates and forms the tube, the sperm nucleus is carried by the tube down through the stigma and style into the cavity of the ovary, and finally through the micropyle of the ovule, until one of the sperm nuclei comes to lie beside the nucleus of the egg-cell. The two nuclei now unite in the process of fertilization to form a fertilized egg-cell. The nucleus of this cell then divides and later the cell-body, thus forming two distinct cells. Each of these divides to form two cells, and the four cells thus produced give rise to eight, then sixteen, thirty-two, and so on, until a many-celled structure is developed which is a miniature plant called the embryo. This embryo, together with other parts of the ovule, constitutes the seed. Some of the cells of the embryo will later form the roots, others the stem, and still others the leaves of the plant (Fig. 29, A-E).

Hence, the new plant formed by this method of reproduction is clearly descended from two different parents, one parent flower furnishing in its pistil the egg-cell and the other in its stamen the fertilizing pollen. We may, therefore, give the following as a general definition of the process we are studying: Fertilization is the union of the nucleus of 


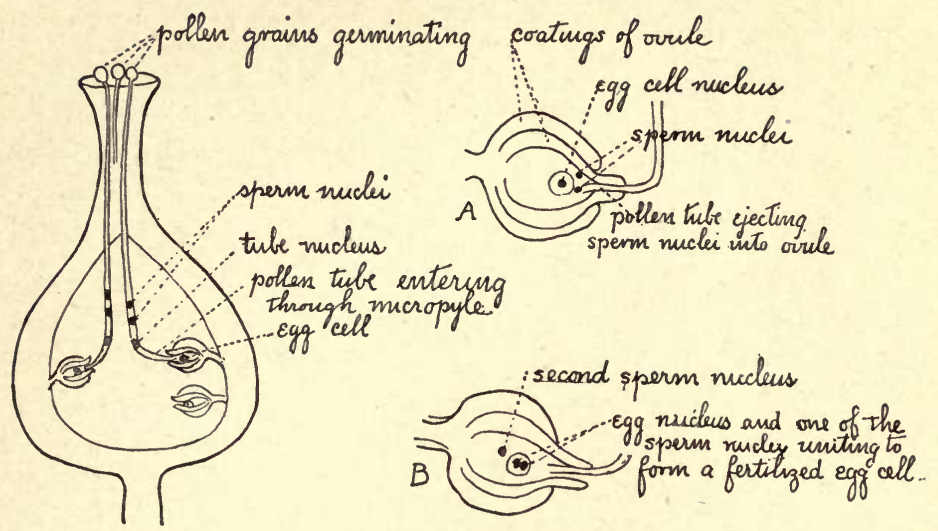

Frg. 28. - Diagram of a longitudinal section of a pistil showing germination of pollen grains.

a sperm cell with the nucleus of an egg-cell.

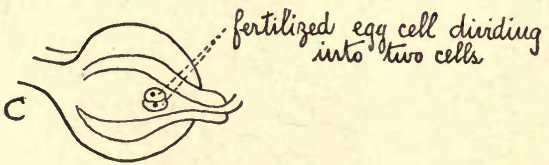
Only one pollen grain or sperm cell can be used in fertilizing each egg-cell. Usually, however, far larger four celled stage of embryo $D$-mucopyle numbers of pollen grains become attached to the stigma than can be used by the ovules in the ovary. All the pollen grains that germinate produce pollen tubes which Frg. 29. - Fertilization of an ovule and may be said to begin a the early stages in the development of race down the stigma and an embryo.-(Diagrammatic.) style. The tubes that first enter ovules are the ones that carry on the process of fertilization. Those that are beaten in the race are of no further use and therefore die. 
92. Self-pollination and cross-pollination. - Pollination, we have said, is the transfer of pollen from the anther to the stigma. When the pollen is carried from the anther of a flower to the stigma of the pistil of the same flower, the process is known as self-pollination. In many of the flowers that are self-pollinated, the anthers are above the stigmas, and when the pollen is ripe, the anthers burst open and allow the pollen grains to fall upon the stigma or stigmas.

If pollen is carried from the anther of a flower to the stigma of the pistil of a flower of the same kind but on another plant, this transfer is called cross-pollination. Cross-pollination is often accomplished by the help of the wind, as in the flowers of the corn, of grasses, and of many trees. In these cases the pollen is dry and light, and the pistils are usually hairy or feathery to catch and hold the pollen grains.

Most bright-colored and sweet-scented flowers (like the pansy and the clover) are visited by bees or other hairy insects which carry pollen on their mouth parts, bodies, and legs from one flower to another, thus insuring cross-pollination. We shall now study the pansy as a type of insect pollinated flowers.

93. Adaptations of the pansy for cross pollination. Laboratory Study No. 45.

A. Floral envelopes. - When there are two circles to the floral envelopes, an outer composed of green parts and an inner made up of brightly colored parts as in the pansy, distinct names are given to the various parts. The outer circle is called the calyx, and its parts are known as sepals; the inner circle is called the corolla, and each of its parts is called a petal.

1. State the number and color of the sepals.

2. How many petals are there? Describe the color or colors of each. 
3. Locate the pairs of petals that are nearly alike in size and shape.

State the position of the odd petal.

4. On which of these petals do you find the most striking spots or lines of color?

5. Make a drawing of the pansy in its natural position, front view, and natural size. Label top petals, side petals, lower petal, hairs on side petals, color spots.

6. Remove the two upper petals, and the two side petals. Now observe the tapering projection on the lower or odd petal extending upward and backward between the sepals. This is called the spur.

a. Tell what you have done and seen.

$b$. Carefully remove the lower petal with the spur attached, and make a drawing of it, natural size. Label the spur and color spot.

7. Slit open the spur. Is the spur hollow or solid?

8. The spur contains a sweet liquid called nectar which attracts the bees and other insects. If you find any nectar, describe it and tell how you found it. Describe the taste of the nectar.

9. In what two ways, therefore, may pansies attract bees?

10. On which petal would a bee be most likely to alight in visiting a pansy? What is there on this petal to guide the bee toward the supply of nectar?

11. (Optional.) What structures on the side petals might make it difficult for the bee to insert its mouth parts in this region?

B. Stamens.

1. Observe the stamens arranged around the pistil. Carefully separate them with a needle or pin. State the number and situation of the stamens:

2. Carefully bend two or more stamens away from the pistil, and with the help of a magnifier look 
on their inner surface. Tell what you have done, and state whether the openings in the yellow anthers from which the pollen is discharged are found on the inner surface (next the pistil) or on the outer surface of the anther.

C. Pistil.

1. Examine the pistil after the stamens have been removed. Carefully describe the three parts (ovary, style, and stigma) of which it is composed.

2. Observe a tiny cavity on the tip of the stigma. The inside of this cavity is the real stigma or stigmatic surface. Describe the shape and state the situation of the stigmatic surface.

D. Cross-pollination of the pansy by bumblebees.

1. Hold a pansy in its natural position.

$a$. State the situation of the stamens with reference to the odd petal (i.e. are they above or below this petal?).

$b$. On what, therefore, will pollen probably fall if it is shaken out of the anthers?

2. To determine whether or not what you have just stated is true, thrust a slender tooth-pick under the stigma and then under the stamens and into the spur. Shake the flower gently and then withdraw the tooth-pick and examine the surface with a hand magnifier. Tell what you have done and statewhether or not pollen is found on the tooth-pick.

3. Examine a bumblebee. On what part of the insect (i.e. mouth-parts, head, or body) would the pollen be most likely to fall when the bee

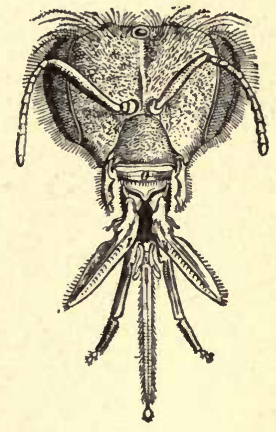

FIG. 30. - Head of a bee. 


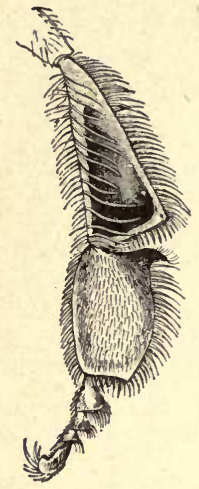

Fig. 31.- Hind leg of a worker bee.

thrusts its mouth-parts into the spur as you have just done with the tooth-pick? How are all these parts adapted to hold pollen? (Compare with Figs. 30,31 .)

4. Still holding the pansy in its natural position, notice and state the position of the stigma with reference to the odd petal.

5. Now push a tooth-pick which has pollen on it, a second time into the spur. State whether or not the toothpick hits the stigmatic cup before you get it under the stigma.

6. Why, therefore, will a bee that has just been to one pansy flower be almost certain to deposit pollen on the stigmatic cup of the next pansy it visits?

7. (Optional home work.) Write a paragraph on "The Visit of a Bee to a Pansy Blossom," giving a complete account of what the bee does and how it does it.

94. The advantages of cross-pollination in the pansy. - Charles Darwin, the great English biologist, proved by a long series of experiments that seeds produced as the result of cross-pollination develop into far more healthy plants than do the seeds which are formed after self-pollination. Among the plants with which he experimented was the pansy (Viola tricolor). He planted in each of five pots seeds that had been produced by cross-pollination, and an equal number of seeds that were the result of self-pollination. The results of the experiments are given in his own words as follows: "The average height of the fourteen crossed plants is here 5.58 inches, and that of the fourteen self-fertilized 2.37 ; or as 100 to 42 . In four of the five pots, a crossed plant flowered before any one of the self-fertilized; as likewise occurred with the pair raised during the previous year. These plants without being disturbed were now 
turned out of their pots and planted in the open ground, so as to form five separate clumps. Early in the following summer (1869) they flowered profusely, and being visited by humble-bees set many capsules which were carefully collected from all the plants on both sides. The crossed plants produced 167 capsules, and the self-fertilized only 17 ; or as 100 to 10 . So that the crossed plants were more than twice the height of the self-fertilized, generally flowered first, and produced ten times as many naturally fertilized capsules.

"By the early part of the summer of 1870 the crossed plants in all the five clumps had grown and spread so much more than the self-fertilized, that any comparison between them was superfluous. The crossed plants were covered with a sheet of bloom, whilst only a single self-fertilized plant, which was much finer than any of its brethren, flowered. The crossed and self-fertilized plants had now grown all matted together on the respective sides of the superficial partitions still separating them; and in the clump which included the finest self-fertilized plant, I estimated that the surface covered by the crossed plants was about nine times as large as that covered by the self-fertilized plants. . . .

"The ensuing winter was very severe, and in the following spring (1871) the plants were again examined. All the self-fertilized were now dead, with the exception of a single branch on one plant, which bore on its summit a minute rosette of leaves about as large as a pea. On the other hand, all the crossed plants without exception were growing vigorously. So that the self-fertilized plants, besides their inferiority in other respects, were more tender.

"Another experiment was now tried for the sake of ascertaining how far the superiority of the crossed plants, or to speak more correctly, the inferiority of the self-fertilized plants, would be transmitted to their offspring. The one crossed and one self-fertilized plant, which were first raised, had been turned out of their pot and planted in the open ground. Both produced an abundance of very fine capsules, from which fact we may safely conclude that they had been cross-fertilized by insects. Seeds from both, after germinating on sand, were planted in pairs on the opposite sides of three pots. 
The naturally crossed seedlings derived from the crossed plants flowered in all three pots before the naturally crossed seedlings derived from the self-fertilized plants.

"The average height of the six tallest plants derived from the crossed plants is 12.56 inches; and that of the six tallest plants derived from the self-fertilized plants is 10.31 inches; or as 100 to 82. We here see a considerable difference in height between the two sets, though very far from equalling that in the previous trials between the offspring from crossed and self-fertilized flowers. This difference must be attributed to the latter set of plants having inherited a weak constitution from their parents, the offspring of selffertilized flowers; notwithstanding that the parents themselves had been freely intercrossed with other plants by the aid of insects." ("Cross and Self Fertilization in the Vegetable Kingdom.")

Darwin, therefore, proved conclusively by these careful experiments (1) that pansy blossoms which were cross-pollinated produced ten times as many seeds as those that were self-pollinated; (2) that the plants developed from these seeds, produced as a result of cross-pollination, were far more vigorous and prolific; and (3) that the descendants of the plants produced by self-pollination, even when their flowers were cross-pollinated, were not able to develop seeds capable of as vigorous growth as the descendants of plants produced continuously by cross-pollination.

95. Prevention of self-pollination. - We have found that the pansy is well adapted to bring about cross-pollination, and since, as Darwin proved, cross-pollination results in seeds being formed. which produce much more vigorous and fruitful plants, we should expect that the pansy would have developed some means of preventing self-pollination; and this, as we shall see, proves to be the case.

The anthers of the pansy, as we saw, are joined about the pistil so as to form a band, and the openings for the escape of 
pollen are on their inner surfaces, next to the style and ovary. When the pollen is shaken out of the anthers, it first collects in the space between the anthers and the pistil. In the natural position of the pansy blossom it should be remembered that the pistil is directed downward, and the end of the stigma rests on the lower petal, with the stigmatic cup opening outward and away from the anthers. Between the two anthers, on the under side of the pistil, and at the end nearest the stigma, there is a V-shaped notch from which the pollen may readily escape when the flower is shaken by the wind or insects. Since the notch is immediately over the groove in the lower petal, the pollen falls into this groove and cannot unaided get into the stigmatic cup, since, as before stated, this cup opens away from the direction in which the pollen must fall. That the pansy pretty effectually prevents self-pollination the following results of some of Darwin's experiments along this line show. Two vigorous pansy plants were selected for the experiment. One was covered with a net so that the bumblebees could not get at the flowers, and the other was left uncovered. In the uncovered one 105 fine capsules were formed, while on the covered one only 18 were formed, and in these only a few good seeds developed; and Darwin states that even the few seeds formed were probably due to the agency of tiny insects that the net could not exclude.

In many other flowers in which both pistil and stamens are present we find other devices for preventing self-pollination. Some of these are as follows: In apple and pear blossoms the stamens usually ripen at different times from the stigmas in the same blossom, so that self-pollination in such cases is impossible. Likewise, when stamens and pistils are in different flowers, as in the pumpkin, corn, and willow, cross-pollination is obviously necessary, if seeds are to be formed. 
Moreover, in case cross- and self-pollination take place in a given flower, it has been proved that the pollen from another flower will usually grow down the pistil more rapidly than the pollen produced in the same flower, and so in such cases fertilization is more likely to result from cross-pollination than from self-pollination.

96. Cross-pollination by insects. - From our study of the pansy we learned that insects are attracted by bright colors and sweet odors. By many observations biologists have
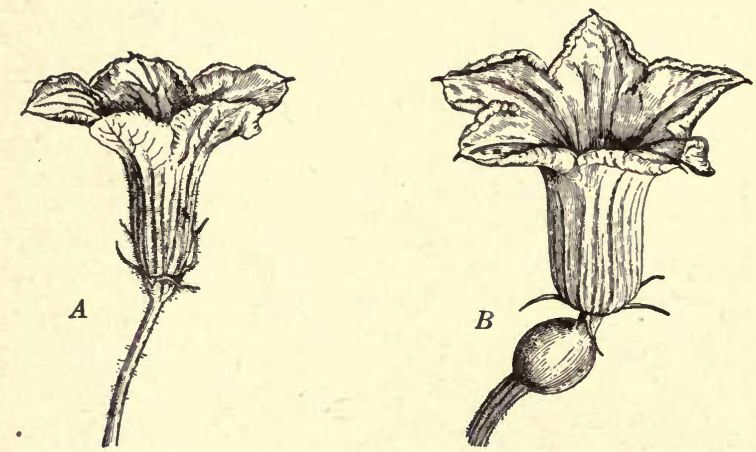

Fig. 32. $-A$, staminate squash blossom; $B$, pistillate squash blossom.

(Bailey.)

learned that most flowers with these characteristics are visited by insects, and that these animals carry pollen from blossom to blossom, thus insuring cross-pollination. Any one familiar with apple, pear, or other fruit trees has seen that at time of blossoming these trees are alive with buzzing bees, and fruit growers know that were it not for these insect visitors their fruit crops would prove a failure. Some plants (the squash, for example) have two kinds of flowers, one kind containing stamens, the other pistils. It is evident, therefore, from what we have already learned that pollina- 
tion, fertilization, and the development of fruit and seeds could not take place in plants like these if there were not some means of transferring pollen from the staminate flowers to pistillate flowers. One has only to watch squash

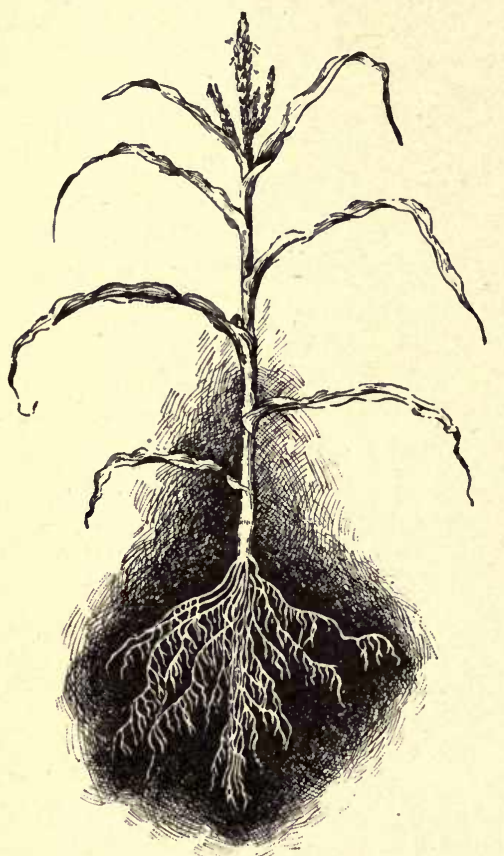

Fig. 33. - Corn stalk with " tassels" (staminate flowers) at the top. - (Duggar.) blossoms on a sunny day to know that bees visit them in great numbers and that their hairy bodies are dusted with yellow pollen as they fly from flower to flower.

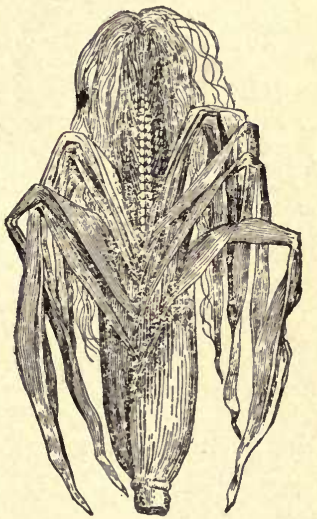

FIg. 34.-Developing ear of corn (pistillate flowers). -(Bailey.)

97. Cross-pollination by wind. - There are many plants, however, which have flowers without conspicuous color or odor; among these are the grasses, the corn, and many common trees like the oaks, birches, and pines. At the top of the corn stalk in midsummer develop the "tassels," and when these are shaken, they scatter great quantities of 
light, dry pollen. On another part of the plant the ears of corn develop. Each ear consists in part of clusters of pistillate flowers, and the threads of silk represent the styles of the pistils. Farmers know that a single corn plant, growing in a place apart from other corn plants, will not form vigorous ears. To secure a good crop, pollen must be carried from the tassels of one plant to the silk of another, and this is accomplished in a garden or a corn field by the wind. Much more pollen must be produced, however, by wind- than by insectpollinated flowers, since in the former case a great deal more is wasted. Many wind-pollinated flowers, such as grasses, have feathery styles to catch and hold the pollen brought by the wind.

\section{Summary and definitions.}

Floral envelopes of a flower $=$ calyx + corolla.

Calyx: 'composed of sepals (often green in color); principal use, to inclose and help protect the essential organs from cold, rain, or biting insects.

Corolla: composed of petals (usually bright colored); principal use to attract insects and so secure cross-pollination.

Essential organs of a flower $=$ stamens + pistils.

Stamens: usually composed of filament and anther; use, to produce pollen grains, each containing a sperm-cell.

Pistil: usually composed of ovary, style, and stigma (or stigmas); use, to produce ovules, each containing an egg-cell, and to insure pollination, germination of pollen grains, and fertilization. 


\section{The Structure and Functions of Fruits}

99. Relation of fruits to reproduction. - We have already learned that the use or function of flowers is to insure the production of seeds. As is generally known, seeds are found in fruits. We are now to study several types of fruits.

100. Study of the bean or pea fruit. - Laboratory Study No. 46.

A. Outside of the fruit.

Study if possible young pods, well-developed pods, and pods that have dried; or charts may be used to show the developing pods.

1. Name and describe the structure which attached the pod to the plant.

2. The main part of the fruit or pod is the pistil, which in the bean or pea flowers consisted of ovary, style, and stigma. Which of these parts are found in the fruit you are studying? (Fig. 35.)

3. Bean and pea blossoms have calyx, corolla, stamens, and pistil. What parts of the flower are present in the fruit? What parts have disappeared?

4. Make a drawing, natural size, of the fruit you are studying in the position in which it hung on the plant. Label fruit-stalk, calyx (if present), and the parts of the pistil that you find.

B. Inside of the fruit.

Split the pod lengthwise into halves.

1. Carefully move one of the seeds in the pod; is it free from the pod, or is it attached?

2. (Optional.) The region of an ovary to which seeds are attached is called the placenta (as was also the case in the ovary of flowers). Locate the placenta in the fruit you are studying.

3. (Optional.) State whether or not you find any undeveloped seeds. Undeveloped seeds probably never were fertilized. 
4. Draw, natural, size in the position in which the pod hung on the plant the opened fruit. Label wall of ovary, developing seeds (undeveloped seeds, if present), seed-stalk.

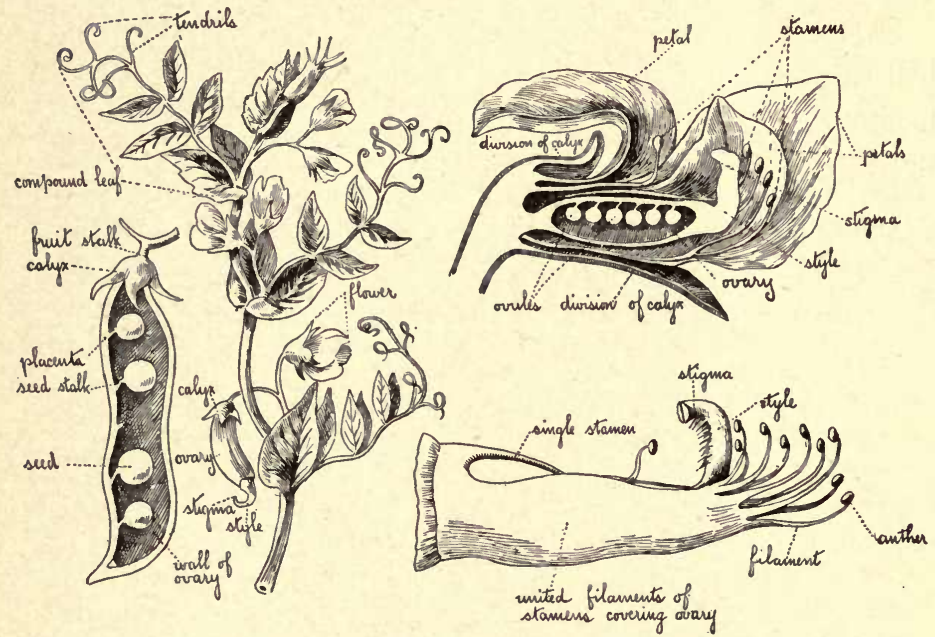

Fig. 35. - Development of the pea fruit from the pea flower. - (Drawn from Jung Chart.)

101. Study of the cucumber, Tokay grape, cranberry, or tomato fruit. - Laboratory Study No. 47.

A. Outside of the fruit.

1. All of the fruits named above are developed ovaries.

Describe the shape and color of the fruit you are studying.

2. Make a drawing, natural size (or an inch in diameter in case the grape or cranberry is used). Label fruit-stalk (if present), ovary.

B. Inside of the fruit.

Cut a cross section of one of the fruits you are studying.

1. Carefully move one of the seeds within the fruit; is it attached or is it free? 
2. Make a drawing, natural size (or an inch in diameter in case the grape or cranberry is used), of one half of the fruit, and show method of seed attachment.

3. (Optional.) Pinch a seed of one of the fruits between your thumb and forefinger. Is it hard or soft? Is it dry or slippery? Of what advantage are these characteristics?

102. Seed dispersal. - It is evident that stronger plants will be developed from seeds if the latter are carried some distance from the mother plant, for then they will not be shaded by the mother plant, and the young plants will have more light, air, food, and moisture, if they are not crowded together. We shall now study some of the devices by which plants secure the dispersal of their seeds.

103. Seed dispersal by wind. - Laboratory Study No. 48. Study one or more of the following fruits :-

A. Winged fruits.

1. The maple fruit.

a. Find the fruit stalk, the two cells of the ovary each containing a single seed, the wing attached to each cell of the ovary.

Hold between yourself and the light a maple fruit in the position in which it hung on the tree, and draw it $(\times 2)$. Label fruit-stalk, cell of ovary, containing one seed, wing, veins of wing.

$b$. Hold one of the fruits some distance above the desk and let it fall. Describe the movements of the fruit in falling.

c. Of what use are the wings if the wind were blowing while the fruit is falling, or after the fruit has fallen to the ground?

$d$. Is the maple fruit a dry or a fleshy fruit?

2. The linden fruit.

a. Notice the wing-like attachment on the fruit-stalk. Do the linden fruits occur singly or in clusters? 
Is the fruit hard or soft? Draw in the position on which it hung on the tree $(\times 2)$ the fruit that is given you. Label main fruit-stalk, winglike attachment, single fruit stalk, fruit.

$b$. c. $d$. Answer questions given under 1 (above).

3. The elm fruit or ailanthus fruit.

a. Notice the fruit stalk, the single-celled ovary, the wing about the ovary.

Draw $(\times 2)$ one of the above-named fruits. Label fruit-stalk, ovary, wing.

$b$. c. $d$. Answer questions given under 1 above.

B. Tufted fruits (or seeds).

1. The clematis, dandelion, thistle, or aster fruit.

$a$. Find the tiny seed-like ovary, containing a single seed, and the tuft of hair. Draw $(\times 2)$ one of the fruits. Label ovary; tufts of hair.

b. c. d. Answer questions under $A$, above.

2. The milkweed fruit and seed.

a. (Optional.) Study Fig. 36. Describe the way the pod opens when it is ripe. Are the seeds many or few?

Draw one of the fruits (pods) to show the method of opening. Label fruit-stalk, ovary, seeds, style.

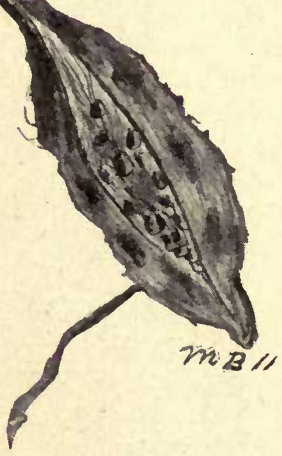

Fig. 36. - Milkweed pod opening.

b. Examine one of the seeds that has been detached from the pod. Draw $(\times 2)$ one of the seeds with its tuft of hair. Label seed, tuft of hair.

c. Drop one of the tufted seeds out of an open window when a breeze is blowing or fan a seed in the laboratory. State your observation. What is one use of the tuft of hair? 
104. Seed dispersal by animals. - Laboratory Study No. 49. Study one or more of the following fruits:

A. Burs and stickers.

1. Cocklebur.

$a$. Hold one of the fruits between yourself and the light. Do the hooks all curve toward one end of the fruit or in several directions?

Notice the two larger projections at one end of the fruit. These are the styles. Draw $\left({ }^{\circ} \times 2\right)$ the outside of one of the cockleburs, showing the direction of the hooks. Label ovary, hooks, two styles (large prongs at one end of fruit).

b. Rub one of the cockleburs on a rough surface of your clothing and try to remove it. By what means does it cling to the cloth? How is a cow or other hairy animal adapted to disperse this fruit?

2. Burdock.

a. Each burdock consists of a large number of individual fruits. Hold the burdock to the light. In what directions do the hooks extend? Why is this an advantage in securing the distribution of fruits?

$b$. Answer questions under $1 b$ above.

3. Bidens (also called pitchforks or beggar's ticks).

$a$. Hold the fruit to the light or examine it with a hand magnifier. In what direction do the little barbs on the two prongs of the ovary extend? Why is this an advantage?

Draw $(\times 2)$ one of the bidens fruits. Label ovary, prongs, barbs.

$b$. Answer questions in $1 b$ above.

B. Fleshy fruits. Suggested as home work.

1. In what ways are the seeds of apples, cherries, and of many other fleshy fruits protected while they are ripening? 
2. Many fleshy fruits are dispersed by birds and other animals which are seeking food. How are these animals rewarded for doing this work?

3. How are the seeds of ripe peaches and cherries, for example, protected from injury?

105. Fruits and their classification. - If one were asked to give examples of fruits, one would doubtless give such forms as apples, cherries, and peaches: But it is doubtful if he would think of including among fruits, pea pods, pumpkins, chestnuts, and corn. To the botanist, however, these are

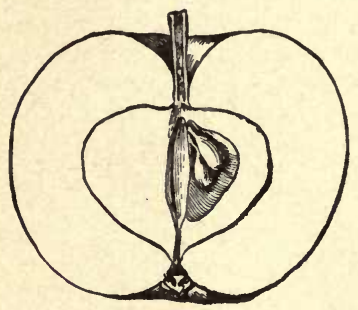

FIG. 37. - Lengthwise section of apple fruit, showing seeds attached to a central placenta. - (Bailey.)

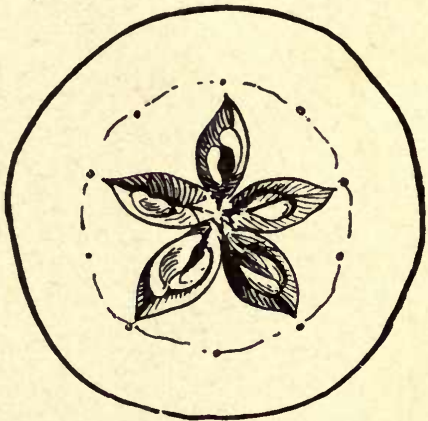

Fig. 38.-Cross section of apple fruit, showing seeds and their coverings which constitute the core.

considered to be just as truly fruits as the forms commonly thought of as fruits. Let us see why such diverse plant products as those just named are all included under the heading of fruits. Technically, a fruit is a ripened ovary and its contents with any other part of the plant that is closely incorporated with it; and since the forms named above are all ripened ovaries containing one or more seeds, it is evident that, strictly speaking, they must be classed with the fruits as much as apples and cherries.

Sometimes the flower contains a number of pistils which form a pulpy mass, such as the raspberries and blackberries 
(see Fig. 40); hence each of these so-called berries is composed of a number of separate fruits. Sometimes the end of the stem which bears the pistils becomes pulpy and juiey and the dry pistils are embedded in its outer surface, as is the case with strawberries (see Fig. 42). In other fruits the ovary may form a hard woody wall, as in the nuts like the chestnut (Fig. 39) and acorn, or the wall may be like a tough paper, as in the pods of peas and locusts (Fig. 43). In still other forms the whole ovary may become fleshy, as in the true berries, such as the cranberry, grape, and tomato. Or we may find a combina-

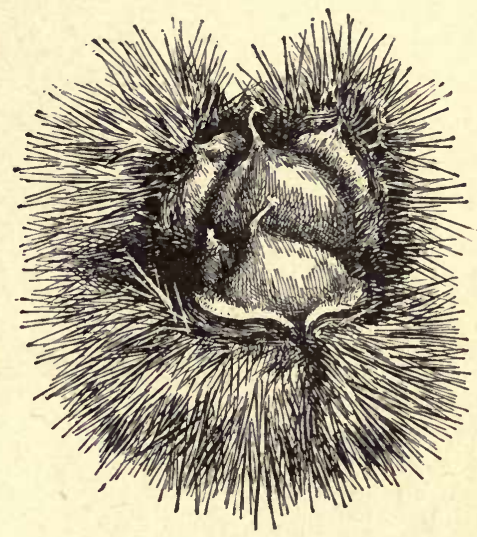

FIG. 39. - Chestnut fruits inside the chestnut bur. - (Bailey.) tion of a tough wall and a fleshy interior, as in the pumpkin, squash, and cucumber. In cherries, plums, and peaches the ovary forms two kinds of material, the inner very hard and

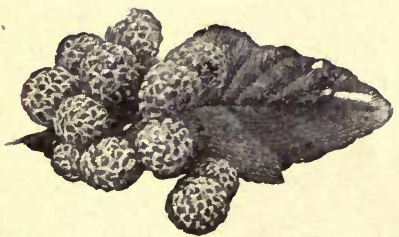

FIG. 40. - Raspberry fruits. stone-like and the outer pulpy. In fruits like the corn grain and the wheat kernel the ovary wall is so closely united with the coats of the single seed that these grains are commonly considered as seeds.

The facts just stated with regard to different kinds of fruits suggest a simple form of classification, based largely on the characteristics of the ovary walls. Thus, for instance, all those fruits, such as bean pods, 


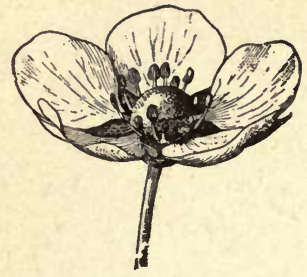

Fig. 41.- Flower of the strawberry. - (Bailey.)

grains, and nuts, in which the walls are dry at maturity, are called dry fruits. Those in which the walls are pulpy throughout, as in the tomato, are termed fleshyfruits; and those which are partly fleshy and partlystone-like, as in the cherryand peach, are called stone fruits.

Another scheme for classifying fruits is based upon the fact that some fruits break open when ripe and scatter their seeds,

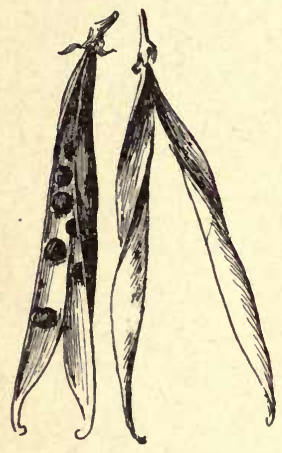

Fig. 43. - Pea pod. (Bailey.) while others remain closed. Examples of fruits of the first kind

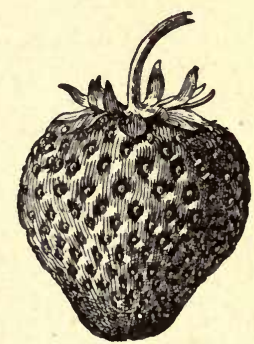

Fig. 42. - Strawberry. - (Bailey.) are the bean, milkweed, and pansy, and of those that remain closed are cherries, apples, and grains. Whether or not a fruit breaks open at maturity depends upon the character of the ovary wall, and this in turn determines, as we shall now see, the method by which its seeds are dispersed.

106. Home work on fruits. - Laboratory Study No. 50. (Optional.)

Classify the fruits with which you are familiar in a table like the following:

\begin{tabular}{|c|c|c|c|c|c|c|c|}
\hline $\begin{array}{l}\text { Name } \\
\text { OF Fruit }\end{array}$ & $\begin{array}{c}\text { DrY } \\
\text { FruIT }\end{array}$ & $\begin{array}{c}\text { Fleshy } \\
\text { Frutt }\end{array}$ & $\begin{array}{c}\text { Stone } \\
\text { FruIt }\end{array}$ & $\begin{array}{c}\text { OPEN } \\
\text { WHEN } \\
\text { RIPE }\end{array}$ & $\begin{array}{c}\text { Closed } \\
\text { When } \\
\text { Rtpe }\end{array}$ & $\begin{array}{c}\text { SEEDS } \\
\text { DIS- } \\
\text { PERSED } \\
\text { BY WIND }\end{array}$ & $\begin{array}{c}\text { SEEDS } \\
\text { DIS- } \\
\text { PERSED BY } \\
\text { ANIMALS }\end{array}$ \\
\hline Cherry & & & $\mathrm{X}$ & & $\mathrm{X}$ & & $\mathrm{X}$ \\
\hline
\end{tabular}




\section{CHAPTER VIII}

\section{PLANT PROPAGATION}

\section{Seeds and their Development into Plants}

107. Study of the bean seed and the development of the bean seedling. - Laboratory Study No. 51 .

Materials: Dry bean seeds and seeds that have been soaked for 24 hours. Sprouted bean seeds and seedlings grown as follows: To secure early stages, put seeds that have been soaking for 24 hours between layers of wet blotting paper, or bury them in moist sawdust, and allow them to stand in a warm place for two or three days. For older stages of bean seedlings plant soaked seeds in boxes containing moist sawdust, sand, or earth. If some of these boxes are put in a warm place and others in a cool place all stages may be obtained in two to four weeks.

1. What difference do you notice in the size of the dry and soaked seed? How do you account for this difference?

(Optional.) Half fill a bottle with dry bean seeds, and add water enough to fill the bottle. Allow the seeds to soak for 24 hours. How much do beans increase in size when soaked?

2. On one edge of a soaked seed find a scar called the hilum, which marks the place where the bean was attached to a small stem which connected it to the pod. Locate the hilum, and state what caused this scar.

3. Make a sketch about two inches long of the seed, showing the edge on which the scar is found. Label scar or hilum. 
4. Pinch a soaked seed, and notice the opening near the hilum through which water is forced from the seed. This opening is called the micropyle (Greek, micro $=$ tiny + pula $=$ gateway) .

a. Describe the position and appearance of the micropyle. What is the derivation of the word?

$b$. Sketch the micropyle in your drawing in 3 above.

5. Carefully remove the seed-coat from a soaked bean. All the structures within this seed-coat together form a little bean plant, called a bean embryo. Break off one of the two halves and make out the following parts of the bean embryo: 1) the two thickened halves of the bean called the seed leaves or cotyledons; 2) a little sprout, the first stem or hypocotyl (Greek, hypo = beneath + cotyl = cotyledon); and 3 ) the two tiny folded leaves forming the first bud or plumule, lying between the cotyledons.

a. State what you have done to show the parts of the embryo.

$b$. Name and describe each of these parts.

c. Place the cotyledon you have removed close to its

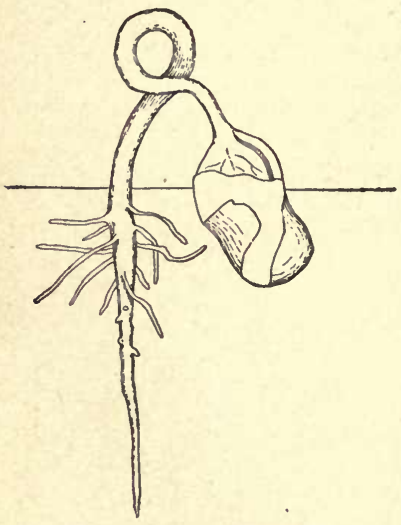

FIG. 44. - Germination of castor bean. - (Osterhout.) point of attachment to the hypocotyl, and make a drawing about two inches long, showing all the parts named above, labeling each part.

6. Examine a bean seed that has just begun to sprout.

a. Name the part of the bean embryo that first breaks through the seed-coats.

b. Make a drawing about two inches long, to show the sprouted seed. Label. 
7. Look at a pot of young seedlings that are just pushing their way above the surface of the soil or sawdust. $a$. Which part of the embryo first appears above ground?

b. What is the shape of this part?

8. Study a whole seedling at this stage (see 7 above), from which one cotyledon has been removed.

a. Describe the changes that have taken place in each part of the embryo since the seed began to sprout.

$b$. Describe the position and appearance of the main root and its branches that appear in this stage.

c. Make a drawing, natural size, of a seedling at this stage and show by a horizontal line the ground level. Label each part.

9. Study a well-developed seedling, comparing it with the stages already drawn, and answer the following questions :

$a$. What changes in the size of the cotyledons do you notice as the seedling grows older? Most of the food for the early development of the seedling is furnished by the cotyledons; suggest, therefore, the cause of the change in size of the cotyledons, which you have noticed.

b. What parts of the developing embryo have changed in color during germination; how have they changed?

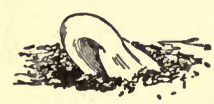

A
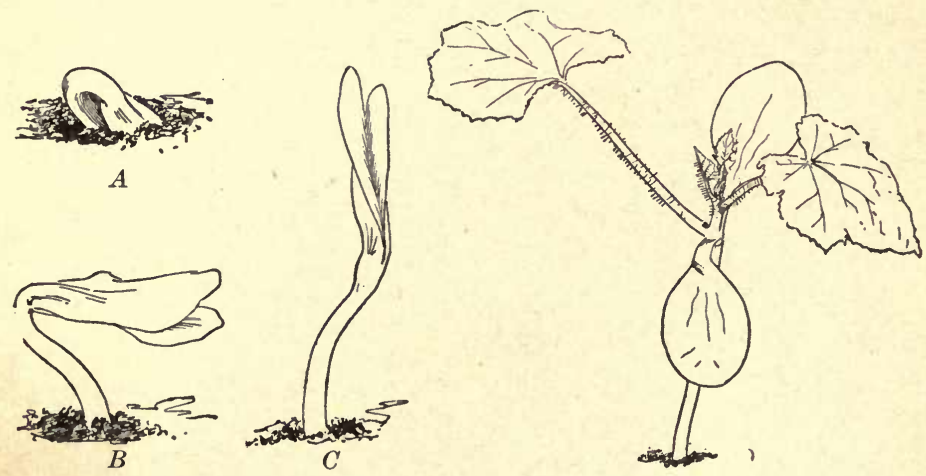

FIG. 45. - Stages in the development of the squash seedling. - (Bailey.) 
c. What parts of the oldest seedling have developed from the plumule?

10. Draw the oldest stage of the bean seedling, and label main or primary root, root-branches or secondary roots, ground level, cotyledons (or scar left by cotyledons), hypocotyl, stem above cotyledons (epicotyl), leaves, terminal bud.

108. Study of the corn seedling and its development from the corn grain. - Laboratory Study No. 52. (Optional.)

Materials: Dry and soaked corn grains; seedlings of various sizes grown as described above for the bean seedling. Corn grains should be planted with the pointed end down.

The structure of the corn grain and the development of the corn embryo can be understood much more easily if the study of the corn seedling is made first, and later that of the corn grain.

\section{A. Seedling just breaking ground.}

1. Examine a pot of seedlings that are just pushing their way through the soil or sawdust, and study a

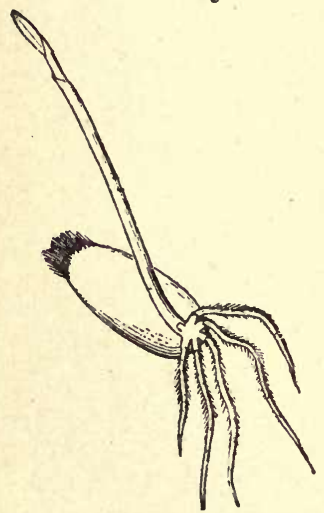

FIG. 46. - Wheat Seedling. seedling of this stage that is given you. All the parts of the seedling above the corn grain have developed from the first bud or plumule.

a. What is the shape of the part that first breaks through the soil? b. Look for the sheath leaf surrounding the unfolding leaves, and trace it down to the ridge around the stem from which it springs. How does this sheath or first leaf of the plumule differ from the unfolding leaves? What is its probable use?

2. Observe the scar on the grain, showing where it was fastened to the cob, and notice the shape of the 
grain at its opposite end. Does the plumule develop from the blunt end or the pointed end?

3. Make a sketch of the seedling $(\times 2)$ and label grain of corn, scar where grain was attached to the cob, stem of plumule, sheath leaf, unfolding leaf, main root, rootlets, soil line.

B. Corn grain just sprouting.

1. Examine a corn grain that has just sprouted. Recall to mind the end of the grain from which the main root grew. (If you are not sure, look at your drawing, or better yet the seedling.)

a. What part of the little corn plant breaks through the covering first?

$b$. What other part of the embryo shows signs of growth?

2. Remove the thin covering from the grain, and observe an oval body embedded in the corn grain. This is the little corn plant or embryo. How does the embryo differ in color from the rest of the grain?

3. The oval-shaped body from which the root and plumule seem to spring in the grain of corn is called the cotyledon. The remainder of the grain is endosperm, which is the food material for the development of the embryo. Make a sketch of the seedling at this stage $(\times 2)$ and label single cotyledon, plumule, endosperm or food material, main root.

\section{Corn grain.}

1. Very carefully scrape away a little of the surface of the cotyledon of a dry or soaked grain till the other parts of the little plant or embryo come into view. Make out the plumule and main root.

Sketch the corn grain and label cotyledon, plumule, tiny root, food material around the plant (endosperm).

2. Cut a corn grain in such a way as to divide the embryo and endosperm lengthwise in half. Put one half in iodine. Where in the corn grain is starch present? Where is it absent? 


\section{Corn seedling well advanced.}

1. What changes have taken place during the development of the seedling in the roots? in the plumule?

2. How does the veining of the leaves in the corn plant differ from that in the leaves of the bean plant?

3 . Where do you find aërial or air roots on the corn seedling? (Roots growing above ground are aërial roots.)

4. Pinch the grain between your fingers. What changes do you notice in the amount of food material? How can you account for these changes?

5. Make a sketch of the seedling and label corn grain, cotyledon, stem, leaves, aërial roots, soil roots.

\section{Suggestions for growing seedlings at home. (Optional.)}

A. Window box. - Secure a wooden box at least six inches in depth, and of a convenient size to place in front of a south window, if you have such a window at home. Nearly fill the box with rich earth which has been finely pulverized or sifted. If possible, mix in thoroughly some well-rotted manure and a tablespoonful of prepared fertilizer. Soak your seeds for twenty-four hours, and plant them at a depth equal to four times the thickness of the seeds. Cover the seeds with dirt, press it down firmly, and sprinkle with water till the earth is thoroughly moistened to a depth of at least four inches. See that your garden is kept as nearly as possible at a temperature of 70 degrees. Add enough water day by day to keep the ground moist.

B. Tumbler garden. - Secure several pieces of blotting paper or other porous paper, and cut it about as wide as the tumbler is high. Wet the paper and roll it into a hollow cylinder that fits inside the tumbler. Between the blotting paper and the glass place the soaked seeds with their hilums in several different positions. Fill the interior of the tumbler with wet sawdust, cotton, or crumpled paper. Cover the tumbler loosely and keep the contents moist, and at a temperature of about 70 degrees.

C. Glass-plate garden. ${ }^{1}-$ Secure two pieces of glass about $5 \times 7$

1 The authors are indebted to Dr. Cyrus A. King, Head of Department of Biology of Erasmus Hall High School, Brooklyn, N. Y., for this method of germinating seeds. 
inches (picture negatives cleaned in hot water are admirable for this purpose). Upon one of the glasses put a layer of wet cotton wadding about half an inch thick. Arrange the seeds (which have been soaked for 24 hours) with their hilums in several different positions, and place on top of them the second plate of glass. Tie strings about the two glasses, and stand the "garden" in about an inch of water. The water will rise between the glasses and keep the developing seedlings moist. After the seeds have begun to sprout, turn the "garden" so that it rests on another edge, and note the effect on direction of growth of the hypocotyl.

\section{Observations to be made on the development of each seed}

1. What part of the seedling first appears above ground? (Make drawings.)

2. Does this part come up straight or in the form of an arch?

3. What kind of veining is found in the leaves?

4. How many cotyledons are present, and what is their use?

5. In what direction does the main root tend to grow? the secondary roots?

110. Comparison of seeds and seedlings. - Study No. 53 . (Optional.)

Soak and plant at home as directed under Materials (107), several kinds of seeds. Study the seeds and seedlings, and fill out in your note-book a table like the following:

\begin{tabular}{ll|l|l|l|l}
\hline \hline & & BEAN & PEA & SQUASH & Corn, ETC. \\
\hline Number of cotyledons. . . & - & - & - & - & - \\
\hline Position of stored food. . . & - & - & - & - & - \\
\hline Kinds of food present... & - & - & - & - \\
\hline
\end{tabular}


Function of cotyledons (Storage of food)

(Absorption of endosperm) (Foliage)

Method of breaking ground . (By arched hypocotyl) . (By arched plumule) (By erect pointed plumule)

Veining of foliage leaves (Netted) . (Parallel)

111. Nutrients stored in corn grains for the use of the seedling. - Laboratory Study No. 54. (Optional.)

Grind with a mortar and pestle some corn grains till a fine meal is prepared. Test for each of the food substances and fill out in your note-book a table like the following:

\begin{tabular}{|c|c|c|c|}
\hline Name of Nutrient & Chemical Used & RESULT & Conclusion \\
\hline $\begin{array}{l}\text { Starch . . } \\
\text { Grape sugar } \\
\text { Protein . } \\
\text { Fat }{ }^{1} \cdot \text {. . . } \\
\text {. }\end{array}$ & 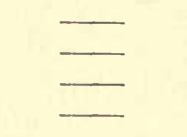 & 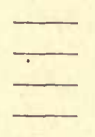 & $\bar{\square}$ \\
\hline
\end{tabular}

112. Of what importance is the endosperm in the development of corn seedlings? - Laboratory Study No. 55. Home work or demonstration.

Soak twenty-four or more corn grains over night. Carefully remove from half of them all the endosperm (food

1 To test for fat, put some of the cornmeal into a test tube, add some ether, shake frequently, and let the tube stand for a time. At the end of twenty-four hours pour'off the clear liquid upon pieces of glazed paper. After the ether has evaporated, hold the paper to the light. Be careful not to hold the ether near a flame. 
materials) from around the embryo corn plant. Plant the corn grains and the corn embryos in rich soil, covering both with the same depth of earth, and marking the location of the two sets. Put them in a warm place.

1. Describe the preparation of the experiment.

2. At the end of two weeks state the number of each group of seedlings that have pushed through the soil.

3. What difference in the size of the two sets of seedlings do you notice at the end of two weeks? at the end of three weeks?

4. What has this experiment taught you?

\section{Other Methods of Plant Propagation}

113. Grafting. - The method often adopted by fruit growers to produce new and better varieties is that known as grafting. This method of plant propagation may be carried on in the following manner. A young shoot, known as the scion (Fig. 47, $A, b$ ), is cut
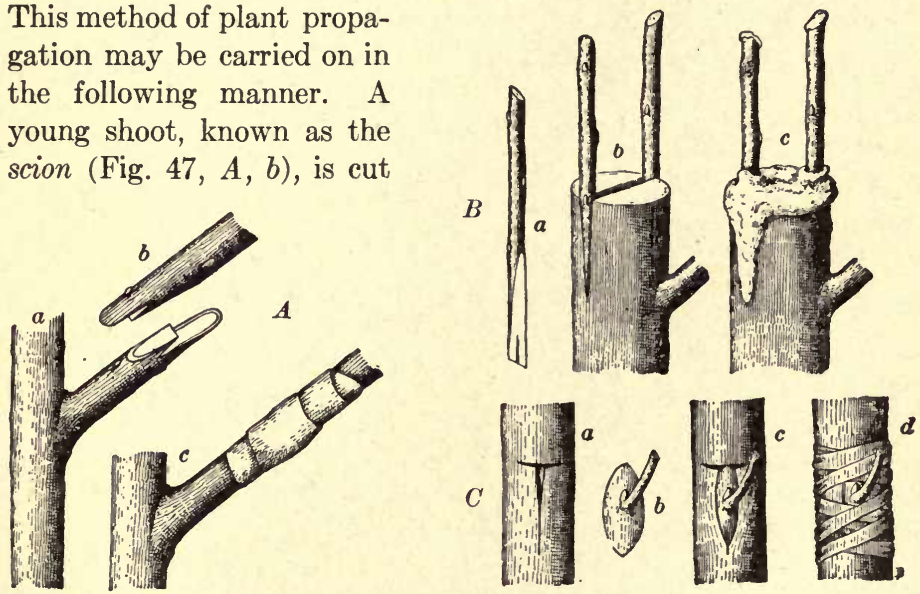

FIg. 47. - Methods of grafting.

in an oblique direction from a tree, the fruit of which is desired, and a similar oblique cut is made across the twig of another tree, called the stock (Fig. 47, $A, a$ ), of a related kind. The two freshly cut surfaces are then closely applied to each other, and the scion and 
stock are bound together by grafting wax (Fig. 47, $B, c$ ), which is put around the outer bark to hold the two pieces in place and to prevent evaporation. In this way the cambium layers of the two plants are brought into close contact and soon unite. The ducts of the stock likewise join those of the scion, and so sap is transmitted to the grafted twig, which grows and develops its fruit as though it were still a part of the plant from which it was taken. There are many different ways of cutting and binding the twigs together, and even buds may be used as scions (Fig. 47, $C, b$ ). But the principle is the same in every case.

Grafting is of necessity employed in producing new plants of seedless grapes or oranges. It is also frequently adopted to combine the desirable characteristics of two different plants. For example, when the vineyards of France were being destroyed by an insect that attacked the roots, the fruit-growers overcame the difficulty by grafting the wine-producing scions upon the more vigorous and resistant nutritive stock of grapevines introduced from America.

114. Slips, runners, and layers. - Another method of producing new plants is that of cutting twigs of plants that are desired, and

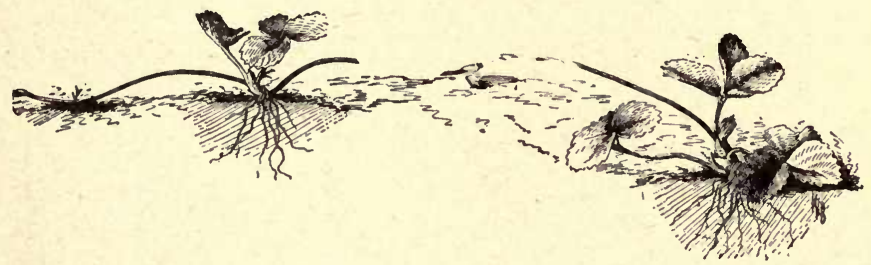

Fig. 48. - Strawberry plant with runner. - (Bailey.)

placing the lower end of the stems in moist sand. Roots soon develop on these so-called slips, and the new plants thus formed can then be transplanted into good rich soil. Any one who has seen a vigorous strawberry plant knows that it sends out a lot of slender stems which grow so rapidly that they are known as runners. When a portion of one of these runners lies upon the surface of moist soil, 
roots are formed as in the case of slips, and when they are firmly established, the connection with the parent plant may be severed, and thus a new strawberry plant secured. Still another method of propagating plants is known as layering, which may be accomplished in raspberry or blackberry plants by burying the tips of branches in the soil, thus inducing the production of roots. The new plant can then be severed from the parent.

115. Tubers. - New potato plants are commonly secured, not by planting potato seeds, but by cutting into pieces a potato which

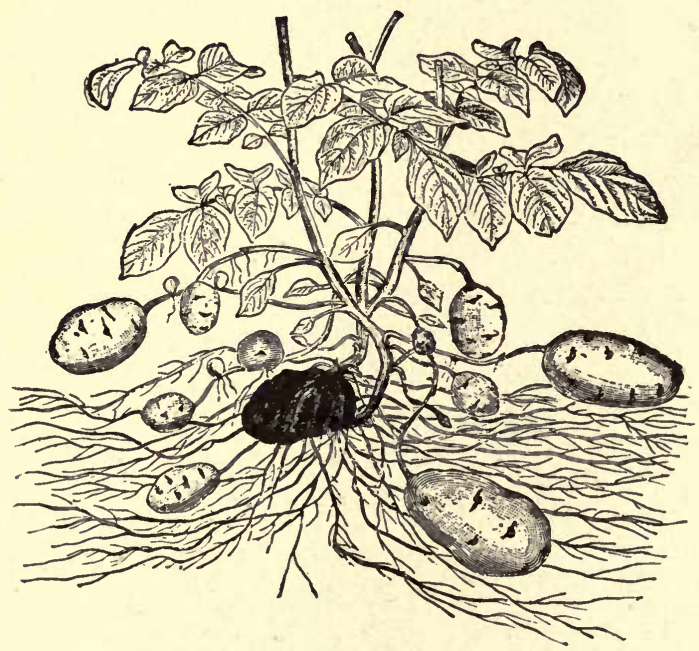

Fig. 49.- Potato plant and tubers grown from dark colored potato in center. - (U. S. Dept. Agriculture.)

is a fleshy underground stem or tuber, each piece having one or more "eyes," and putting these into the ground. In each eye is a bud, and when this sprouts it develops stems and leaves above ground, the new plant thus formed getting a considerable amount of nutrition from the food stored in the tuber during the preceding season. 
116. Bulbs. - Still another method of propagating plants is by means of bulbs, which, in the onion, for example, consist of a short, thickened underground stem, to which are attached many layers of thickened parts of leaves known as bulb-scales. Frequently, as in the tulip and hyacinth, after the food stored in the bulb has been used in the early spring to develop stem, leaves, and flowers, the nutritive organs store away food for another season by producing new bulbs close to the old one.

\section{Home bulb culture. - (Optional.)}

Few plants are easier to cultivate or give greater satisfaction, especially in winter, than those that grow from bulbs. Secure a few tulip, hyacinth, or narcissus bulbs and bury them in pots of rich earth. Water them well and put them in a dark, cool place for four to six weeks, until the roots appear through the opening at the bottom of the pot. Then put them in a warm, sunny place, keep them well watered, and the flowers will appear in a few weeks.

\section{Conditions that are essential for the Growth of Plants}

118. The five essential conditions for plant growth are the following: (1) moisture, (2) favorable temperature, (3) air, (4) light, (5) food. We have already shown the necessity of air for the germination of seeds (79) and for the liberation of energy (76). The use of the food stored in the corn grain for the corn embryo was also demonstrated in 112 . We have also proved that green plants do not manufacture carbohydrates in the absence of sunlight (30). We can likewise show experimentally the relation of moisture and temperature to the germination of seeds and to the growth of plants.

119. Relation of moisture to germination and growth. - Laboratory Study No. 56. (Optional.) Suggested as home work.

Secure three tumblers of same size (tin covered jelly-tumblers are very satisfactory). In the bottom of each put a piece of 
sponge about half the size of the fist (a wad of cotton or paper will answer). Label the first tumbler No. 1, and place upon the sponge 10 pea seeds that have been soaked for 24 hours. In the second tumbler (labeled No. 2) put 10 soaked peas, and add enough water to come nearly to the top of the sponge. Put 10 soaked pea seeds into the other tumbler (No. 3), and add sufficient water to cover all the peas. To prevent the evaporation of the water, cover the three tumblers, and place them side by side in a moderately warm temperature $\left(65^{\circ}-\right.$ $70^{\circ}$ F.), and label each " Please do not disturb."

1. Which one of the five conditions (enumerated in $\mathbf{1 1 8}$ above) is different for the three groups of seeds?

2. Name all of these conditions which are practically the same for the seeds in all three of the tumblers.

3. At the end of a few days compare the seeds in the three tumbleprs. What percentage of the seeds in each of the three tumblers has germinated?

4. State clearly your conclusion as to the relation of water to the germination of pea seeds.

5. Allow the three tumblers to stand side by side in a warm, light place for several weeks. Describe the changes that take place in each tumbler, and state your conclusion as to the relation of moisture to the growth of pea plants.

120. Relation of temperature to germination and growth. - Laboratory Study No. 57. (Optional.) Suggested as home work.

Prepare three tumblers with sponges (cotton or paper) as in 119 above, putting in water enough to come nearly to the top of the sponge in each dish. In each tumbler place 10 soaked peas, and put on the covers. Label No. 1, No. 2, and No. 3. Set tumbler No. 1 in the refrigerator or in some place where it will not freeze. Keep Tumbler No. 2 at the temperature of the living room. Place No. 3 where the temperature is over $100^{\circ}$. Make sure that all tumblers have about the same amount of light by covering each with black paper or a cloth. By the aid of a thermometer find and record the tem- 
perature of each place where you put a tumbler. Each day look at the tumblers, and if necessary add enough water to keep the level the same in all three.

1. Which one of the five conditions named in $\mathbf{1 1 8}$ is different for the three groups of seeds?

2. Name all the conditions which are practically the same for the seeds in all three of the tumblers.

3. At the end of a few days compare the seeds in the three tumblers. What percentage of the seeds in each of the three tumblers has germinated?

4. State clearly your conclusion as to the relation of temperature to the germination of pea seeds.

5. Allow the three tumblers to stand in the three different temperatures for several weeks. Describe the changes that take place in each tumbler, and state your conclusion as to the relation of temperature to the growth of pea plants.

121. The soil. - "From the soil all things come; and into it all things at last return; and yet it is always new, and fresh, and clean, and always ready for new generations. This soft, thin crust of the earth - so infinitesimally thin that it cannot be shown in proper scale on any globe or chart - supports all the countless myriads of men, and animals, and plants, and has supported them for countless cycles, and will yet support for other countless cycles. In view of this achievement, it is not strange that we do not yet know the soil and understand it; and we are in a mood to be patient with our shortcomings." 1

Even a casual examination of the soil in any region shows that it has a complex structure. Usually it is composed of some coarse particles known as gravel, finer grains called sand, and still more minute ingredients, the mud or clay. The relative proportions of these constituents determine whether the soil is a gravelly soil, a sandy soil, or a clayey soil. The soil particles to which we have

1 Bailey's " Cyclopedia of American Agriculture," Vol. I, "Farms,", p. 323 . 
referred supply the mineral ingredients needed by plants in the form of soil-water. But soil, to be fertile, must contain a considerable quantity of vegetable mold, the so-called humus, a dark brown or black substance produced by the decay of vegetable matter. This is the reason that florists mix with the dirt in their flower-pots a handful of material obtained from the floor of the forest (see frontispiece), where leaves have fallen and decomposed year after year.

122. Moisture. - If the student has tried the experiment in 119, he will have been convinced that the amount of moisture supplied to seeds or plants has a great deal to do with their development. Soils in very dry or arid regions are deficient in water, and this must be supplied by irrigation. In semiarid regions proper methods of tillage, as we shall see, will do much to keep the soil in a proper condition for plant growth, so far as moisture is concerned. Very moist or "heavy" soils, on the other hand, are unfavorable for the growth of most plants, and so the excess of water must be removed by drainage.

Reviewing some of the facts already learned, we see that a large supply of water must be secured by plants from the soil, because -

"1. A living plant contains a large proportion of water-generally more than 75 per cent of its weight.

"2. Large quantities of water must pass through the plant in order that the food solution in the soil may be carried to the leaves, and the substances that it contains may be converted into organic matter. This water loss takes place by transpiration from the leaves and growing shoots.

"Careful and extended experiments in this country and Europe have shown that 300 to 500 tons of water are taken from the soil by the various crops for each ton of dry substance produced." 1

123. Relation of the soil to air. - When the interstitial spaces between the particles of soil are not filled with water, or when they are only partly filled, they contain air. The air which circulates in ${ }^{1}$ Bailey's "Cyclopedia of American Agriculture," Vol. I, "Farms," p. 353 . 
the soil differs in composition from the air above the surface. As a rule, the soil air contains less oxygen and more carbonic acid $\left(\mathrm{CO}_{2}\right)$, ammonia, and vapor of water. The increased amount of carbonic acid and ammonia have their origin in the organic matter or humus. A soil is not in the best condition for the production of crops unless there is within its depths a free circulation of air. This is true because oxygen in the soil is as essential for the life of the plant as it is for the animal. . . .

"When the soil is full of water to within a few inches of the surface, there can be no circulation of air among its particles. Adequate ventilation can be provided for such a soil only by drainage. Drainage ventilates the soil by lowering the ground water three or four feet, and thus makes it possible for the roots of plants to penetrate soil more deeply. In time these roots die and decay and afford passageways throughout the soil for the ready movement of the air." 1

124. Relation of soil to heat. - The influence of the temperature of the soil on crop production is a factor of considerable importance. The life processes of a plant are practically suspended below a certain minimum temperature, which is about 40 degrees Fahrenheit for most cultivated crops. Above this temperature all the vital activities, as germination and growth, increase until the optimum is reached. Above this point these life processes decrease in activity until the point is reached when they cease. The soil is a great factory that has its production vastly increased as the temperature rises. ... The minimum temperature at which corn germinates and also the minimum for its growth is $48^{\circ}$ or $49^{\circ} \mathrm{F}$. Its optimum is about $93^{\circ} \mathrm{F}$. . .

"The sources of the heat of the soil are the internal heat of the earth, the sun, and decaying vegetable matter. It is difficult to estimate to just what extent the internal heat of the earth, which itself is very great, affects the temperature near the surface of the earth. However, the amount of heat from this source is insignificant, is a constant factor, and is entirely beyond the control of man.

${ }^{1}$ Bailey's "Cyclopedia of Agriculture," Vol. IX, "Farms," p. 357. 
Decaying organic matter furnishes some heat to the soil. For example, manure heats the soil to a limited extent when it is spread on the surface and plowed in. . . . The sun is by far the most important source of heat for the soil. When its rays are nearly vertical there is tropical heat; when its rays are withheld, the land is locked in snow and ice. The heat received at the surface passes downward by conduction." 1

125. Cultivation of the soil. - A moment's thought will convince us that since all the food of man is ultimately derived from plants, any measures that tend to improve crops and reduce the cost of crop production are of vital interest to all of us. In the past, before much was known in regard to scientific principles, farmers put their seeds in the ground, cultivated them

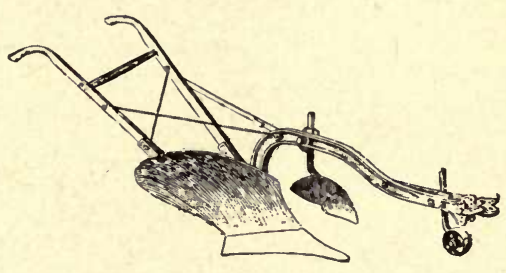

Fig. 50.-A plow. relatively little, and trusted Nature to do the rest. In recent times, however, man has learned a great deal in regard to soils, crops, and methods of cultivation, so that the modern farmer is often able to double the yield of a given area. The investigations of the National and State Departments of Agriculture have done much to make farming a science, and the future will doubtless see far greater improvements.

For the cultivation of plants the first requisite is a suitable preparation of the soil. This involves, in the first place, plowing, which turns under any weeds or other plants that may have grown there before and which prepares for the work of the harrow, an implement which pulverizes the soil so that

${ }^{1}$ Bailey's "Cyclopedia of American Agriculture," Vol. I, "Farms," pp. 355,356 . 
ready penetration of the roots of the growing plant is possible. In small garden plots this work is done by the use of spades, hoes, and rakes. It is often found necessary to add wellrotted manures to increase the humus of the soil and chemically prepared fertilizers, which furnish available mineral

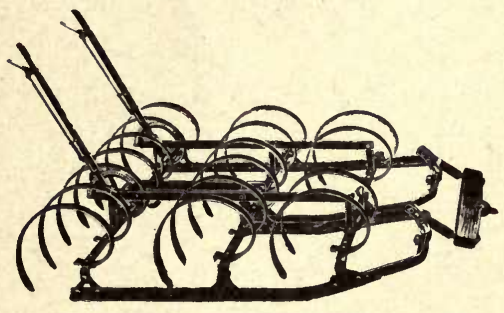

FIG. 51.-A harrow. food for the crops. We have already called attention to the necessity of proper drainage of the soil before crops are planted (122). Scientific investigation has demonstrated, too, that frequent and thorough stirring of the soil is most important not only to prevent the growth of weeds, but also, and this is even more essential, to conserve the soil moisture, and insure proper aëration of the roots. It has been found that it is possible to produce large crops on semiarid land if the top-surface of the ground is kept in a thoroughly pulverized condition. This is the so-called method of "dry farming."

\section{The Struggle for Existence and its Effects}

126. Variation among plants. - We have all heard the common expression "as nearly alike as two peas." In reality, however, if our powers of observation were sharp enough, we should probably find that no two peas are exactly alike in shape, color, size, and weight. The plants grown side by side from any two peas would also vary in height, in number and position of leaves, and in the number and vigor of flowers and seeds. In other words, as every human being has certain distinguishing characteristics, so, too, we should bear in mind that every individual plant, however small, shows certain differences or variations from every other individual of its class. 
127. The numbers of seeds produced by plants. - A second fact which is evident to all is that plants produce an enormous number of seeds. Suppose we consider the case of a vigorous pea-vine. In the course of a season it should produce at least 20 pods, each containing at least 5 seeds. Hence, at the end of a single season, one pea seed would, if conditions were favorable, have multiplied itself 100 times. If each one of these seeds were to be planted where it

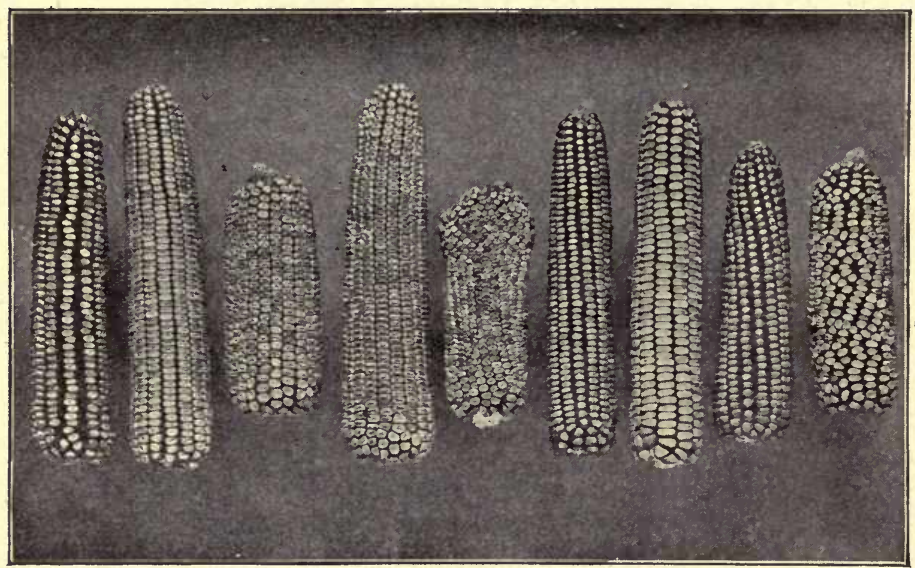

Fig. 52. - Variations in the corn ears produced in a single field.- (Courtesy of Dr. E. M. East, Bussey Institution, Harvard University.)

had plenty of moisture, light, food, air, and favorable temperature, it likewise should give rise to 100 seeds, and so at the end of the second season we ought to have $100 \times 100$, or 10,000 pea seeds, all propagated from a single pea seed. Simple multiplication shows us that at the end of five years a moderately prolific plant like the garden pea would have given rise, had all conditions been favorable to $10,000,000,000$ new seeds. Bergen has made a patient count of the number of seeds produced by an average morning glory plant, and finds it to be rather more than 3000; hence, at the end of the fifth year, if such a rate of reproduction were 
to be continued, there would be $243,000,000,000,000,000$ morning glory seeds. ${ }^{1}$

It is evident, however, that no pea vine or morning glory plant, if left to itself, would be able to produce anything like the number of seeds we have named, for otherwise at the end of a short term of years there would not be room on the whole surface of the globe for any other kinds of plants than these. As a matter of fact, the number of individuals of a given kind of organism does not vary much from year to year. In the first place, many seeds are eaten by birds and other animals. Again, many other seeds are not carried to a place where they find all the conditions that are essential for germination (118). Still other seeds, even if planted in good soil and in favorable surroundings, fail to germinate. Because of the great losses of seeds in one or the other of these three ways, we can get some idea of the reason why plants must produce a great abundance of seeds if their kind is to be perpetuated.

128. The struggle for existence among plants. - But even if seeds finally germinate and get a foothold on the soil, a great many

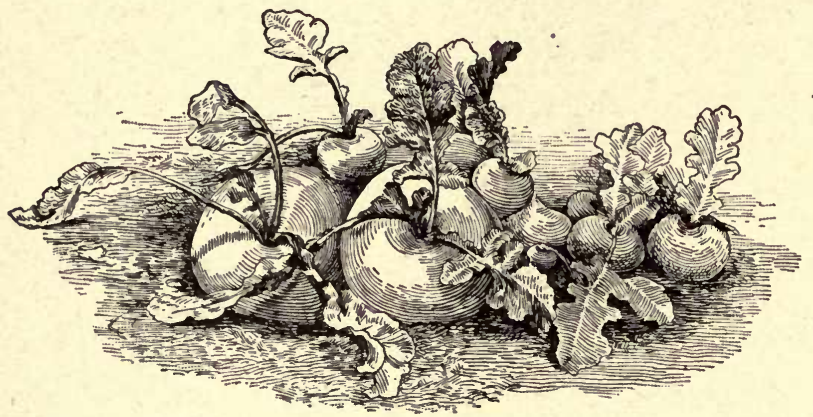

FIG. 53. - The struggle for existence and the survival of the fittest among turnips.

of the plants thus started will never reach maturity and ripen their seeds. In the first place, each plant is struggling to lift up its leaves - $\quad{ }^{1}$ See Bergen's “Essentials of Botany” (1910), p. 202. 
to the light and air, and those that are most vigorous usually get above and shade the others. Again, the supply of water and mineral food in the soil of a given area is limited; hence, plants that cannot get what they need are dwarfed and finally starved to death. In

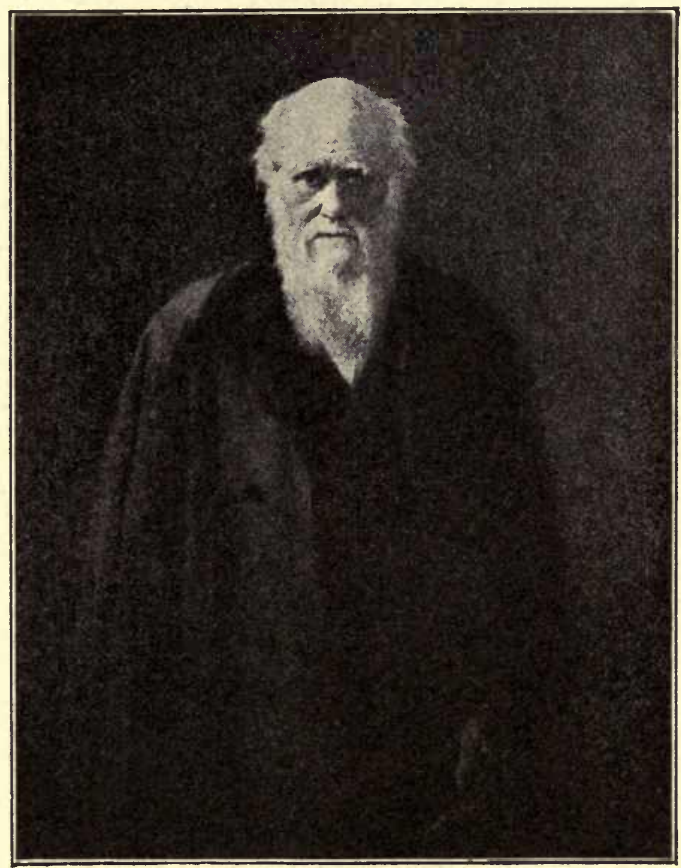

Fig. 54.-Charles Darwin.

the third place, injurious insects destroy an enormous amount of vegetation, the loss of cultivated crops alone from this cause being estimated at $\$ 700,000,000$ annually. Frosts, dry seasons, heavy rains, and fungous diseases are other important factors in the life of many plants. And so if we were able to see what is actually going on in each square foot of the earth's surface, whether of forest, 
field, or meadow, we should doubtless witness a life and death struggle for existence (1) between individual plants, of the same kind, (2) between individual plants of different kinds, and (3) between plants and animals.

Charles Darwin in his great book on the "Origin of Species," published in 1859, - a book which has doubtless influenced human thought more than any other book of modern times, - closes his chapter on the "Struggle for Existence" with the following words: "When we reflect on this struggle we may console ourselves with the full belief that the war of nature is not incessant, that no fear is

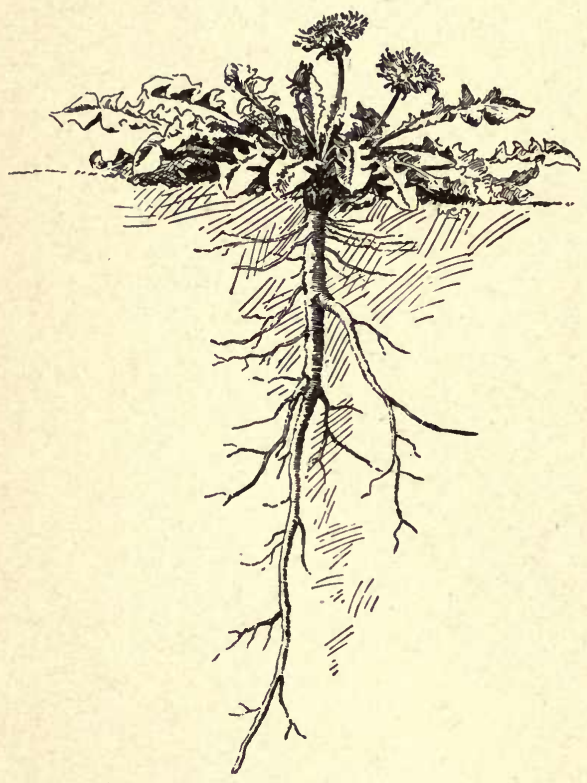

FIG. 55. - Dandelion plant. - (Bailey.) felt, that death is generally prompt, and that the vigorous, the healthy, and the happy survive and multiply." 1

129. The survival of the fittest. - We have seen in our study thus far (1) that no two individual plants even of the same kind are exactly alike, (2) that enormous numbers of seeds are produced by plants, and (3) that there is inevitable competition or struggle for existence. The question, then, that confronts us is this: Which of the many competitors will survive in the struggle, reach maturity, and finally reproduce themselves? Obviously those individual plants that vary from the rest in such a

${ }^{1}$ Darwin's “ Origin of Species,” p. 72. 
way that they can best adapt themselves to their surroundings. Let us see, for instance, why certain weeds like the dandelion are so common a nuisance on our lawns. In the first place these weeds have fleshy roots that reach deep down into the soil, thus helping the plant to get and keep a stock of moisture and food. In the second place the reserve supply of nutrition stored in these roots enables the plants to put forth leaves and flowers in early spring, and so to get a good start ahead of their competitors. Again, their short stems and tough leaves can be trampled upon without killing the plant. Insects and fungous diseases, for some reason, do not seem to attack them. And finally dandelions produce a large number of tiny seed-like fruits, each one of which is provided with a delicate tuft of hair which a puff of wind will carry for a considerable distance, thus insuring a wide dispersal of its seeds. In nature, then, plants like the dandelion, pigweed, and thistle have survived in the struggle for existence, because they are best fitted to their surroundings.

\section{The Improvement of Plants by Man}

130. Artificial selection of favorable variations. - In the preceding pages attention was frequently called to the fact that plants show a tendency to vary more or less from each other. Now it has been found that in a state of cultivation this tendency becomes even more pronounced. A watchful farmer will often find that in his cornfield one group of individuals ripens sooner than the rest, and so if he wishes to sell earlier corn, he selects and plants next year corn grains derived from plants that have varied in this direction. Again, he may notice that the ears on certain stalks are larger and ripen more kernels (see Fig. 52) ; these the crop-raiser who uses his brains would select for seed in order to increase his yield per acre. Variations in many other directions might be chosen by the successful farmer which would add immensely to the value of his crops. It is estimated that if every farmer were to select his seed carefully, the corn production in the United States, which at present is about $\$ 1,000,000,000$, in a short time would be increased 10 per cent, which would add $\$ 100,000,000$ to our annual income. 
131. Artificial crossing of related species. - Not only can man secure new varieties of plants by watching for favorable variations and perpetuating them from year to year, but he can actually be instrumental in producing new kinds of plants. This process is known as plant breeding. It depends fundamentally on the principles we learned in treating of cross-pollination in flowers. Let us illustrate plant breeding by the following account of the work which has been done for the U. S. Department of Agriculture by Dr. H. J. Webber of Cornell University. ${ }^{1}$

In the winter of 1894-1895 a heavy frost destroyed practically every orange tree in the northern and central part of the State

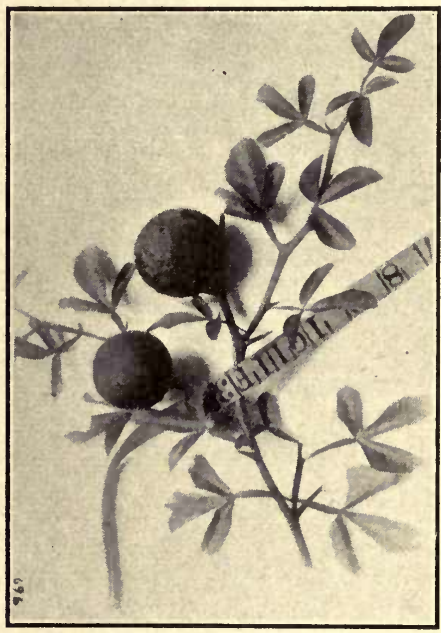

Fig. 56. - Spray from trifoliate orange, showing leaves and fruit. of Florida. The loss was over $\$ 75,000,000$. The problem that confronted the orange growers of the State was that of starting their groves anew and if possible of preventing a repetition of such an experience by planting a more hardy kind of orange tree. Dr. Webber, in casting about for such orange trees, finally chose a type called the trifoliate orange (Fig. 56) often used for an ornamental shrub, and one that would not be killed by winters as far north as Philadelphia. The fruit of this tree, however, is small, bitter, and worthless for eating purposes. His task, therefore, was to combine the characteristics of a juicy, sweet-flavored fruit of the ordinary Florida orange tree with the hardy, cold-resistant character of the trifoliate type. He proceeded in this fashion:

${ }_{1}^{1}$ See Year-books of U. S. Department of Agriculture, 1904, 1905, 1906. 
From the flower-buds of one type of orange trees he removed all the stamens before blossoming time, and then covered the pistils with paper bags to prevent the visit of insects bringing pollen. A second set of buds on trees of the other type were likewise covered with paper bags to prevent possible mixing of pollen by insect visitors. When the stamens of one kind of orange blossoms and the

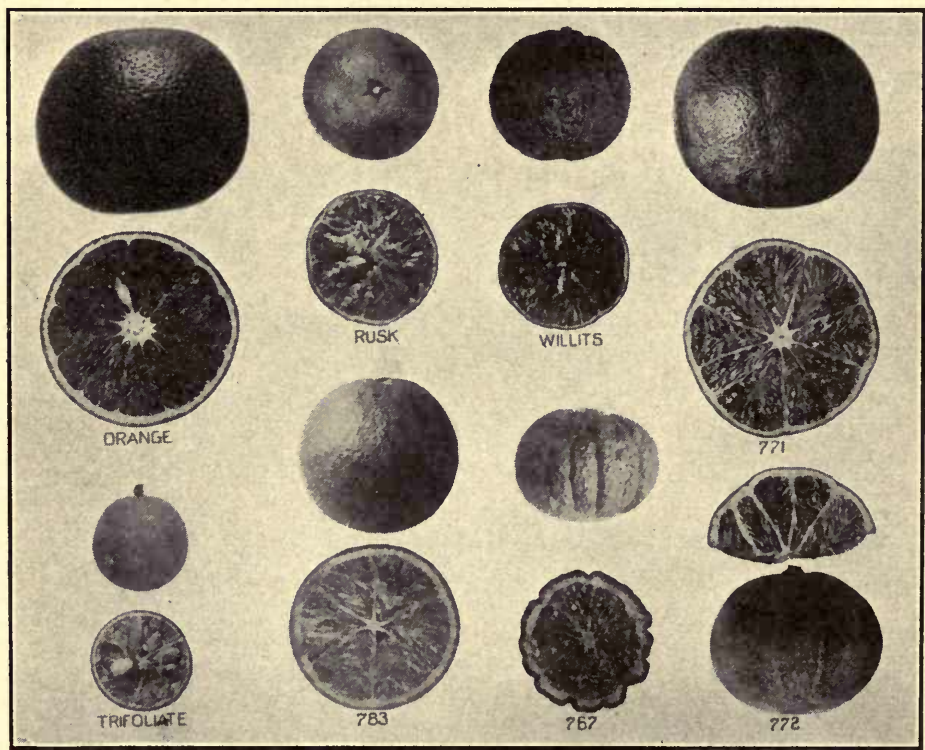

FIg. 57. - Fruits of two parent plants (orange and trifoliate) at left. Six types of hybrid fruits (Rusk, Willits, 783, 771, 772, 767) developed. by cross-pollination from the parent plants, all being good fruits except 767, which proved to be worthless. Compare seeds and pulp in various sections.

pistils of the other kind had matured, the bags were carefully removed, and the pollen of one variety was dusted over the pistil of the other (see 87). The paper bag was then replaced over the artificially pollinated pistil, and the latter left to ripen. Fruits 
formed by the cross-pollination of two different kinds of plants are known as hybrid fruits. The orange hybrid fruits thus developed were sent to Washington, where the seeds were removed and planted in greenhouses. When the young hybrid trees were about a foot high, they were sent to Florida and grown in a garden of the Department of Agriculture.

After a great many experiments in crossing the two kinds of oranges, and after rejecting hundreds of plants that proved to be worthless, Dr.Webber has succeeded in producing a type of tree that will withstand the winters of regions from three hundred to four hundred miles north of the present orange-growing section of Florida, and which will also produce a valuable, juicy fruit. These new fruits, which have been named citranges, make a delightful citrangeade and may be used in making pies, cakes, marmalades, and the like. In a similar way Dr. Webber has produced new varieties of tangerines, pineapples, cotton plants, and grass for hay.

The work of Luther Burbank ${ }^{1}$ in California has likewise resulted in astonishing colors and sizes of pinks and poppy blossoms, in plums and peaches of great size, and in entirely new plants like the "pomato," produced by crossing the potato with the tomato.

132. Some of the valuable crops of New York State. ${ }^{2}-$ New York ranks first of all the States of the Union in the production of the following crops :

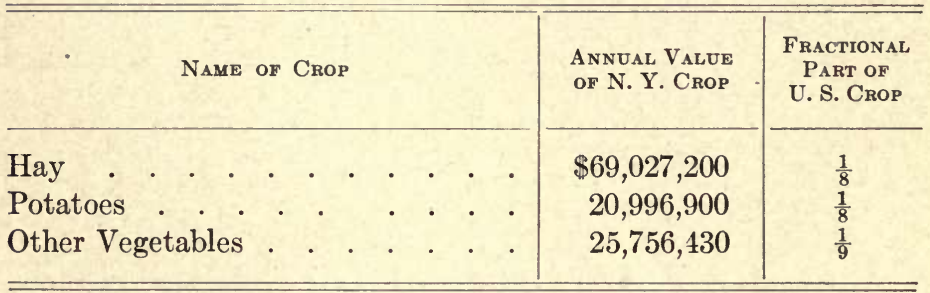

${ }^{1}$ See "New Creations in Plant Life," by W. S. Harwood.

2 The authors are indebted to Professors of Cornell University, for the use of the figures recently compiled. 
(Since dairy products are directly dependent on agricultural conditions, they are also included in this tabulation.)

Dairy Products. Milk

$\$ 55,474,155$

$36,284,833$ $\frac{1}{9}$
$\frac{1}{5}$

In spite, however, of its preëminence among the States in the production of the crops just named, experts tell us that the average yield per acre throughout the State is probably less than half what

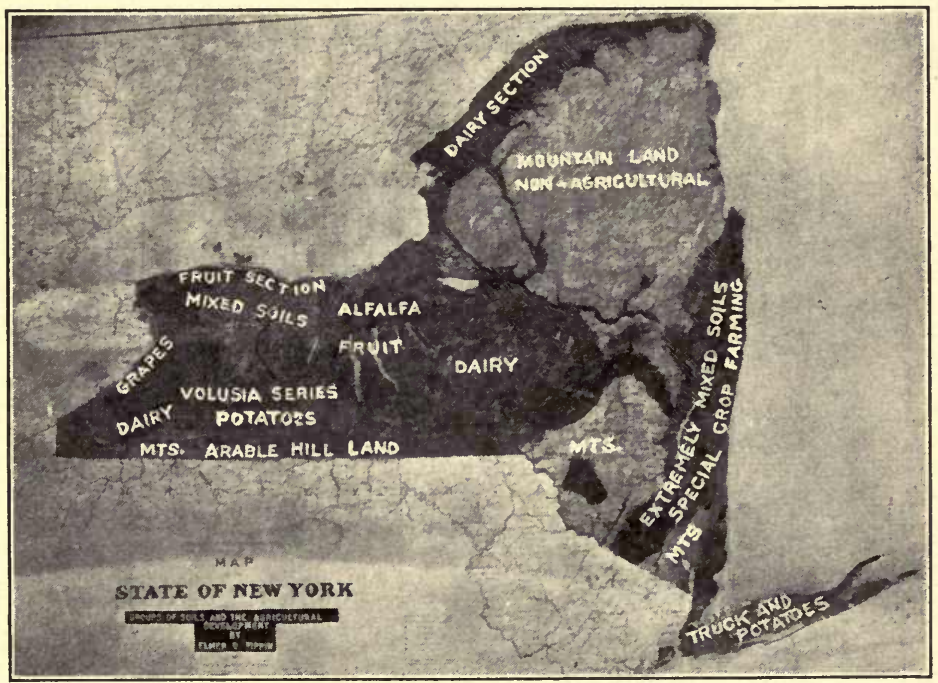

FIg. 58. - Map of New York State, showing the crops grown in various areas. - (Courtesy of Prof. E. O. Fippin, of Cornell University.)

it should be or might be if more intelligence were used by the average farmer. The following quotation from an investigation made among 1303 of the farmers in the vicinity of Cornell University, near the center of the State of New York, shows in a striking way 
the commercial advantage of even a high school education. "Of the owners, those who went only to district school made an average labor income of $\$ 318$. The average labor income of high school men was $\$ 622$. Of the more than high school men (i.e. college, normal, or agriculture courses) it was $\$ 847$. The differences are emphatic. The labor income of the high school farmers is $\$ 304$ greater than that of the district school men. This would be 5 per cent interest on $\$ 6080$. In other words the high school education of a farmer is equivalent, on the average, to $\$ 6000$ worth of 5 per cent bonds." 1

133. Summary of some of the methods employed for increasing crop production. - The farmers of the future,

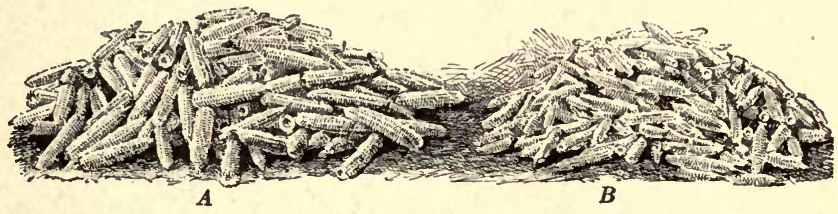

Fra. 59. - $A$, pile of corn resulting from cross-pollination; $B$, pile of corn resulting from self-pollination. - (Bailey.)

therefore, to be successful must have special training. They must be able to carry on selection and breeding experiments, or at least know how to take advantage of these experiments in the choice of their seeds; they should know the principles involved in thorough cultivation and in the application of manures and fertilizers; they should determine by experiment the type of crop best adapted to the soil of their farms, and should by proper rotation of crops (that is, by sowing clover or other nitrogen-fixing plants, 150 , one year and corn the next) increase the fertility of their soil. If a farmer is a fruit grower, he should know how to prune properly, and he

${ }^{1}$ An Agricultural Survey of the Townships of Ithaca, Dryden, Danby, and Lansing, published by Cornell University, 1911. 
should practice grafting to develop better types of fruits. If he has soil adapted for woodland, he should plant forest trees, and put into effect the principles of forestry. In fact, there are countless ways in which the farmer of the future can increase the yield of his acres if he but mixes brains with the labor of his hands. 


\section{CHAPTER IX}

PLANTS IN THEIR RELATION TO HUMAN WELFARE

134. Introduction. - Thus far in our study of plant biology we have considered the principal functions carried on by

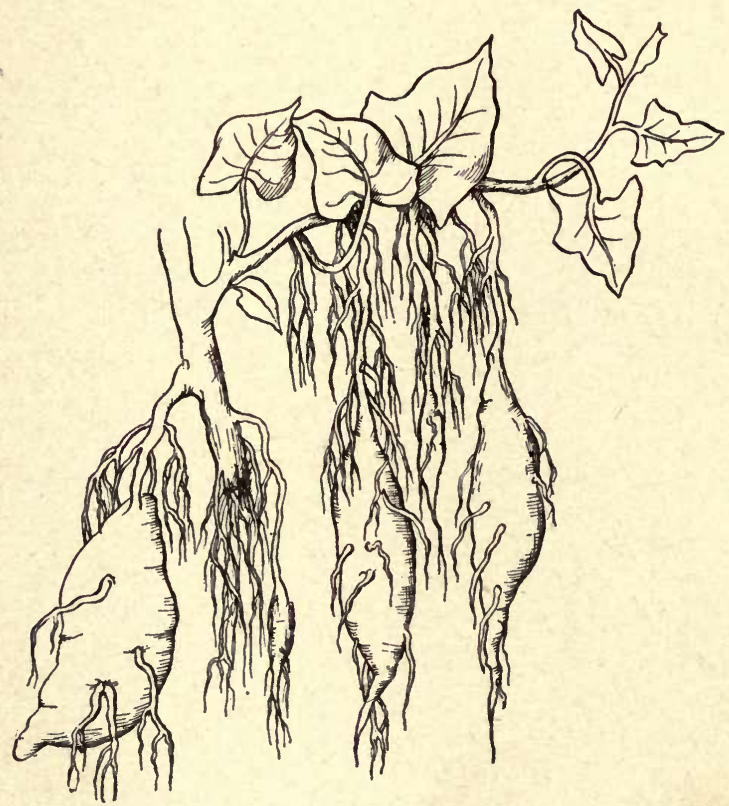

FIG. 60. - Sweet potato plant.

plants and have observed some of the adaptations of structure for performing these functions. We have proved, for example, that plants must feed, digest, breathe, and carry 
on oxidation in order to live and grow, and must reproduce their kind in order to perpetuate the species. We turn now to a discussion of some of the uses of plants to man, and some of the ways in which they are injurious.

\section{Some of the Uses of Plants to MaN}

135. Uses of plants for food. - By repeated experiments we have proved that various parts of plants contain generous stores of starch, sugar, protein, and mineral matters. In our study of human biology we shall find that the foods which are essential for our bodies are composed of these same substances. It is for this reason that man and other animals are so largely dependent upon plants for food. As examples we may mention roots like parsnips, beets, and sweet potatoes; stems, like

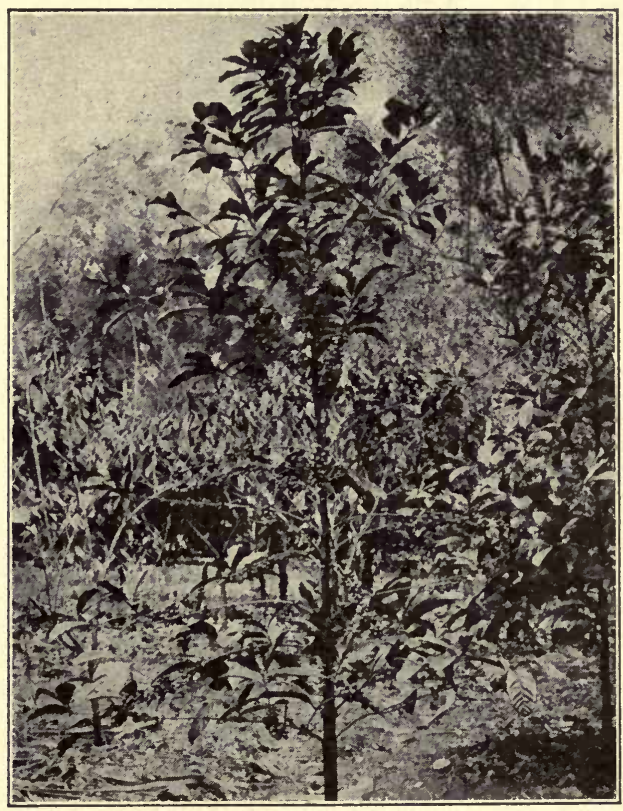

FIg. 61.- Coffee tree. Notice coffee berries along sides of branches. - (Courtesy of New York Botanical Garden.)

common potatoes, asparagus, and sugar cane; leaves, such as cabbage and lettuce; flowers, for example, cauliflower; 
fruits, like apples and peaches; and seeds and grains, like beans, wheat, and corn.

136. Suggestions for further study of plants used as food. Study No. 58. (Optional.) Visit a vegetable market, make a list of the various plant products sold for food, and arrange them in a table as follows:

\begin{tabular}{|c|c|c|c|c|c|c|}
\hline \multirow{2}{*}{ NaMe of Food } & \multicolumn{6}{|c|}{ Part of Plant Eaten } \\
\hline & Root & Stem & Leaf & Flower & Fruit & Seed \\
\hline String beans & & & & & $\mathrm{X}$ & $\mathrm{X}$ \\
\hline
\end{tabular}

Select one or more of the following topics for special study: wheat, corn, potatoes, oats, rice. Consult Bailey's "Cyclopedia of American Agriculture," Vol. II, "Crops," any encyclopedia, or the publi-

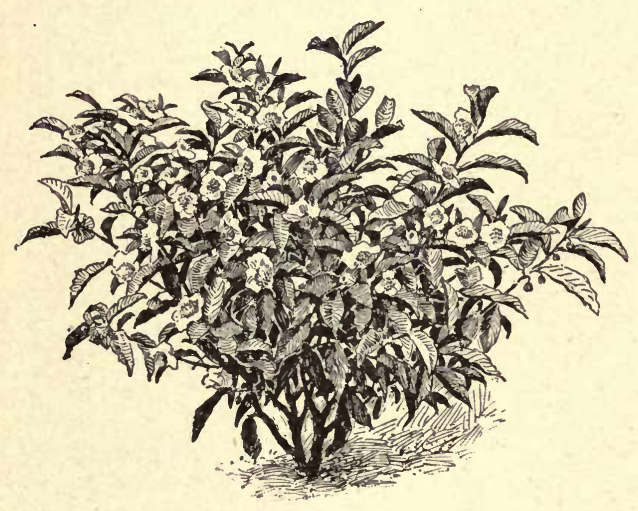

Fig. 62. - Tea plant. - (Bailey.) cations of the U.S. Department of Agriculture. Determine (1) theparts of the United States (or of the world) in which the.crop is raised in large quantity, (2) the amount and value of a year's crop, (3) methods of harvesting and preparing the crop for the market.

137. Uses of plants for flavoring extracts, beverages, and medicines. - We saw in a previous section that many parts of plants are available for use as food by man. Because, 
also, of the presence of various flavoring compounds in plants, the following products are valuable. For instance, vanilla extract is made from the vanilla bean, pepper from pepper berries, horse-radish from the root of the horse-radish plant, and ginger from an underground stem.

We are dependent, too, upon plants for many beverages. The coffee berry supplies us with coffee, tea leaves with tea, and from the pods and seeds of the cocoa tree we obtain cocoa and chocolate. Grapes are used to make wines, from apples cider is prepared, and from grains of various kinds other alcoholic liquors are produced. Quinine, the wellknown remedy for malaria, was formerly obtained from the bark of a tree known as cinchona, which grows in Peru. This medicine is now obtained almost exclusively from trees cul-

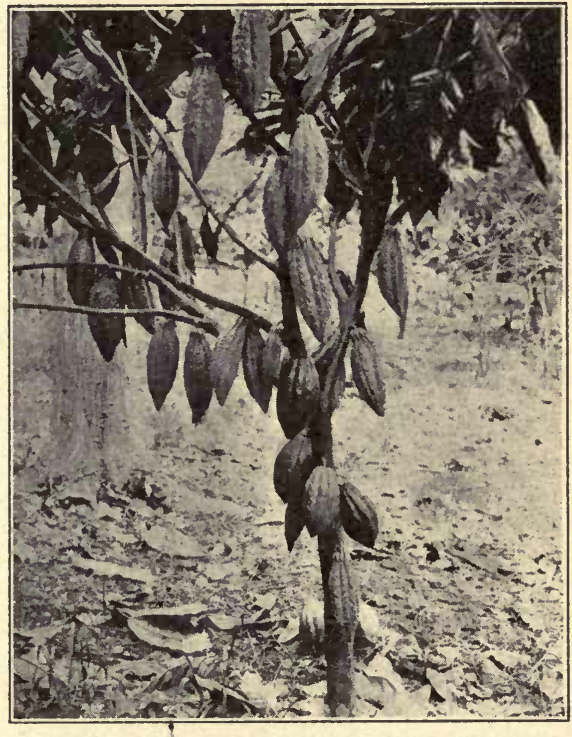

FIG. 63. - Chocolate tree. - (Courtesy of New York Botanical Garden.) tivated in India and other Eastern countries. The camphor tree furnishes camphor gum ; from the juice of poppy fruits opium and morphine are obtained; whole plants like peppermint supply us with valuable medicines. In fact, enormous numbers of drugs are prepared from various parts of plants. 
138. Suggestions for further study of parts of plants used as drugs. - Study No. 59. (Optional.)

Visit a drug store or consult an encyclopedia, e.g. Baiiey's " Cyclopedia of American Agriculture," Vol. II, "Crops," and make a list of common drugs obtained from plants. Fill out in your note-book a table like the following:

\begin{tabular}{l|c|c|c|c|c|c}
\hline \hline Name of Drug & \multicolumn{5}{|c}{ Part of Plant From which it is Obtained } \\
\cline { 2 - 5 } & Root & Stem & Leaf & Flower & Fruit & Seed \\
\hline Catnip & & $\mathrm{X}$ & $\mathrm{X}$ & & & \\
\hline
\end{tabular}

139. Uses of plants for clothing. - (Quoted from Bailey's "Cyclopedia of American Agriculture," Vol. II, "Crops.") "Fiber-producing plants are second only to food plants in agricultural importance. In continental United States, however, cotton, hemp, and flax are the only fiber plants cultivated commercially; and aside from cotton and hemp, most of the raw fibers used in our industries are imported."

"The cotton of commerce is the hair or fiber on seeds of plants belonging to the Mallow family.... The plants are mostly shrubby, more or less branching, and two to ten feet high. . . . The fruit consists of three- to five-celled 'bolls,' which open at maturity through the middle of the cells, each cell liberating seven to ten seeds covered with long fibers. The fiber is a tubular hairlike cell, $\frac{1}{1500}$ to $\frac{1}{1200}$ of an inch in diameter, somewhat flattened and spirally twisted. It is this latter characteristic which gives the cotton its spinning qualities. ...

"Picking or gathering cotton in the fields is a heavy item of expense. It must be picked by hand, as no mechanical appliance for harvesting has yet been invented which gives satisfactory results in practical working. The amount of cotton that one person can pick in one day varies from one hundred to five hundred pounds, 


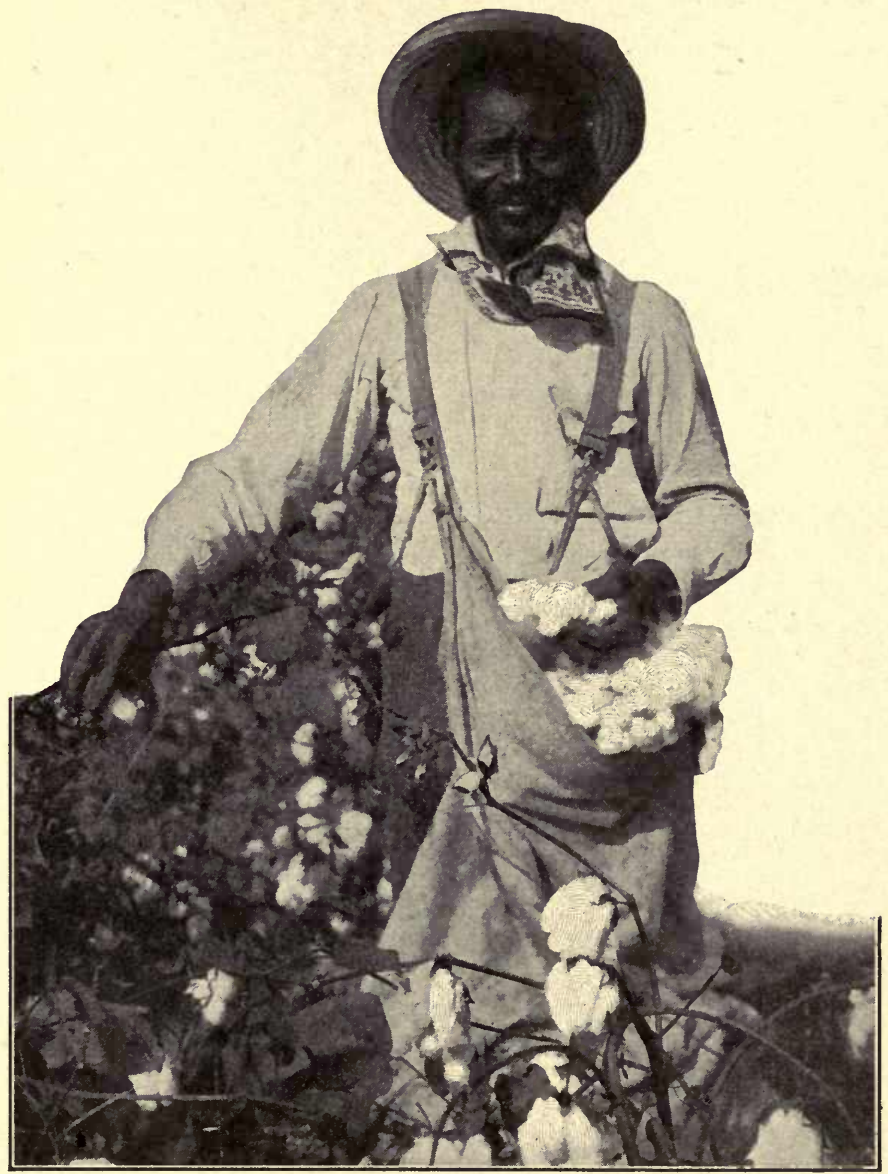

FIG.64.-Cotton picking.

depending on the skill of the picker. One man can very easily care for the cultivation of twenty acres of cotton, but it requires two to four pickers to harvest such a crop rapidly enough to pre- 
vent loss. This extra labor in harvest time is usually supplied by the wives and children of the laborers. The harvest season extends over a period of about four months, beginning August 15 to September 10, according to locality.

"Cotton is probably a native of the tropical and semi-tropical regions of both hemispheres. The earliest records of the Asiatics and Egyptians speak of it; Columbus found it growing abundantly in the West Indies, while other early explorers found it growing in Mexico and South America. . . . There is no region in the world which has such a favorable combination of suitable land, intelligent and plentiful labor, cheap capital and adequate transportation facilities for the cultivation of cotton as the cotton belt of the United States. It has been the chief source of supply of the cotton mills of the world, for in this section has been raised several times the quantity of cotton produced in all other countries of the globe. There are various other countries which seem to possess the soil and climatic requirements for its growth, but for various economic reasons the industry has not been greatly developed in them; however, a considerable quantity is produced in the following countries in the order named: India, Egypt, China, Italy, Turkey, Brazil, West Indies, Mexico, South America, Australia, and the South Sea Islands."

140. Further study of fiber-producing plants. - Study No. 60 . (Optional.) Select one or more of the following fiber-producing plants for further study : flax, hemp, jute, raffia, hat-straw. Consult Bailey's "Cyclopedia of American Agriculture," Vol. II, "Crops," or any encyclopedia. Determine (1) the parts of the United States (or of the world) in which the crop is raised in large quantity, (2) the amount and value of a year's crop, (3) methods of harvesting and preparing the crop for market.

\section{The Uses of Forests and Forest Conservation}

141. Uses of forests for fuel, lumber, and other commercial purposes. - In the earlier days of our country's history all the fuel for heating, for running locomotives and other en- 
gines was supplied from the forests. About one hundred and fifty years ago, coal was discovered in Pennsylvania, and one would suppose that since that time our forests would have been drawn upon less heavily for fuel. But it is estimated that the United States burns annually at the present time one hundred million cords of wood. While we are considering the uses of plants as fuel, we should remember that our

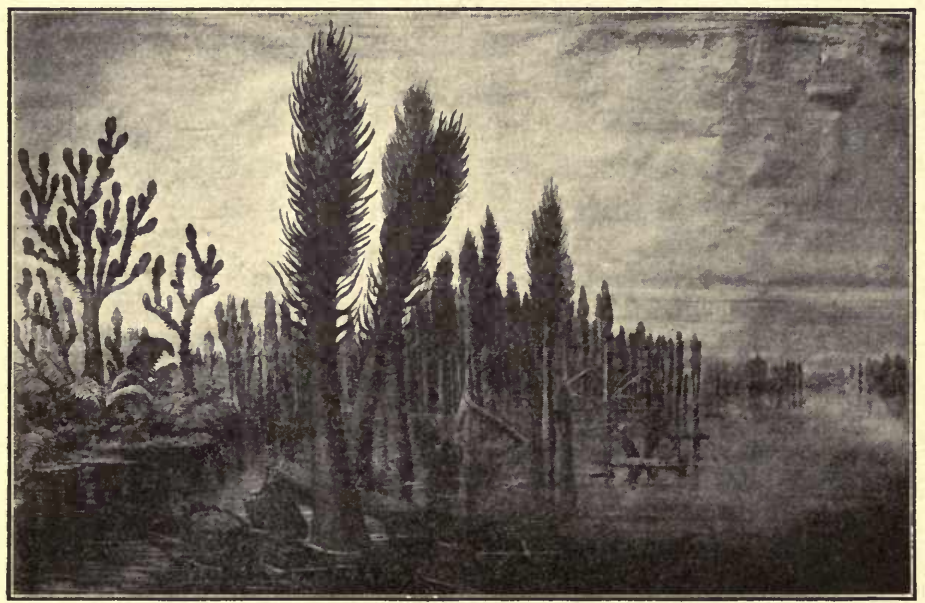

Fig. 65. - A view showing how the forests of the Coal Period probably looked. - (Tarr and McMurry.)

enormous coal beds were without doubt formed from great tree ferns and other plants which lived in bygone ages. Petroleum, too, from which our kerosene oil is produced, is believed to be a product of plant decomposition.

One has but to call to mind the enormous use of trees for framing and finishing houses, for furniture, for railroad ties, telephone and telegraph poles, for shipbuilding, and for boxes, barrels, and paper manufacture, to realize how seem- 
ingly indispensable are forests. When the early settlers reached this country, they found a virgin forest covering the whole land. Their first work was to clear land in order to get open spaces for cultivation and as a means of protection from attacks of the Indians. They cut down the trees ruthlessly and the timber and wood which was not needed was left to decay or become the prey of forest fires. This forest de-

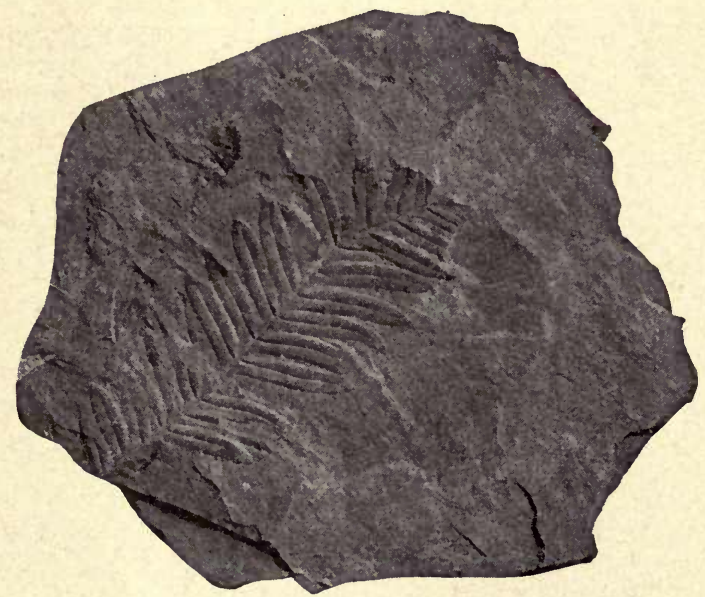

Fig. 66. - Rock containing a fossil fern which grew in the swamps of the Coal Period. - (Tarr and McMurry.)

struction has continued even to our own day. But at last men are beginning to see that unless this slaughter of our trees is stopped, our timber supply will soon be gone. In fact, government experts tell us that if the tree areas that yet remain are not managed according to a different system, twenty years hence we shall reach the end of the timber supply in the United States.

142. Further study of forest products. - Study No. 61. (Optional.) Select one or more of the following forest products for fur- 


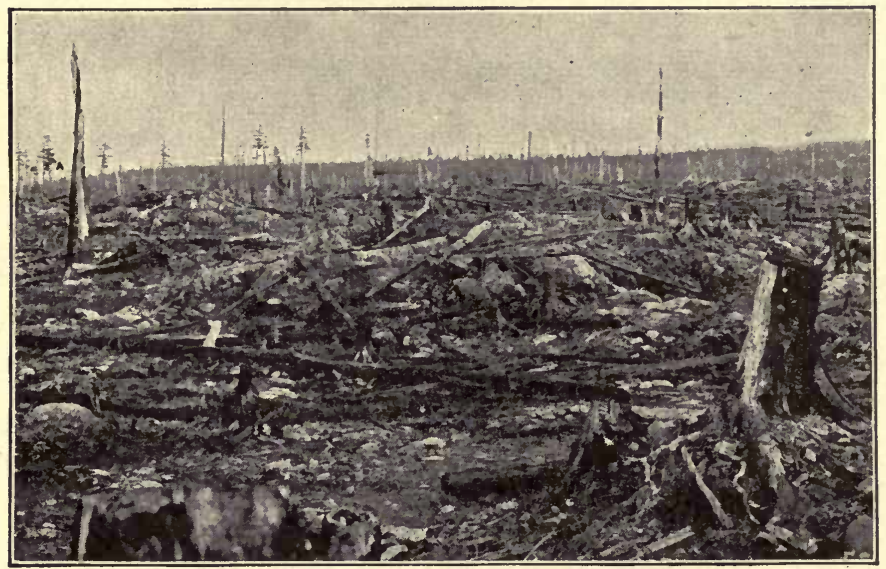

FIG. 67.-Wrong methods of lumbering. - (Warren.)

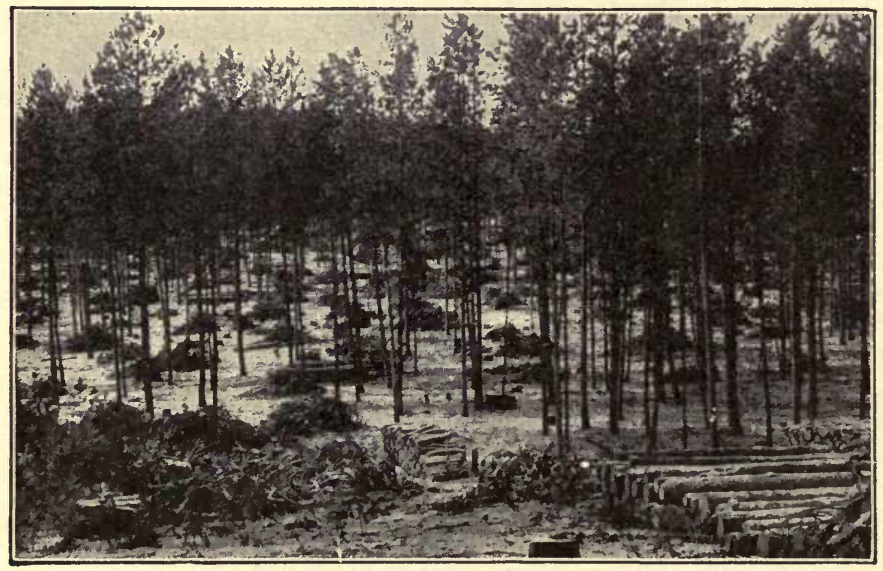

FIG. 68. - Right method of lumbering. Notice carefully piled logs, wood and brush, and uninjured young trees. 
ther study: maple sugar, rubber, tar, turpentine, wood pulp, alcohol, charcoal. Consult Bailey's "Cyclopedia of American Agriculture," Vol. II, "Crops," or any encyclopedia. Determine (1) the parts of the United States (or of the world) in which the product is obtained in large quantity, (2) the amount and value of a year's crop, (3) methods of preparing the product for market.

143. Uses of forests in regulating rainfall and flow of streams. - We turn now from a consideration of our forests as a source of lumber and manufactured products to a discussion of their effect on the fall of rain and the flow of streams. It is probably true, in the first place, that the destruction of large tracts of forest lands means a lessened rainfall, at least so far as local showers are concerned. We saw in our study of the functions of the nutritive organs of a plant that great quantities of water are absorbed by the roots, carried up through the woody bundles of the stem, and given off through the stomata of leaves. It has been estimated that a single oak tree of average size gives off in a single season over one hundred and twenty-five tons of water. If we were to multiply this amount by the number of trees in a forest, we would get some idea of the enormous amount of water lifted into the air by this agency.

Not only do trees help to produce rain; they also conserve the rain when it falls by holding it in the soil, and preventing disastrous floods. Let us see how this is brought about. When the raindrops fall upon the tree tops, the water drips from leaf to leaf, and finally reaches the ground. Here it trickles down through the floor of the forest, which is formed of thick layers of decaying leaves, interlacing roots, and earth particles (see frontispiece). All these form a porous sponge which absorbs and holds back the water. Suppose, now, the trees are removed from the hillsides. When the rains come, there is no means of absorbing the water; instead, it flows 
rapidly over the surface, swelling the streams into torrents, which bring destruction and death as they flood the valleys and fields along their course. As the water flows over the surface of the land from which the trees have been cut, it carries along the richest part of the soil, thus causing loss of fertility in the uplands. The material thus carried away fills up the river beds and harbor mouths, and in many cases a heavy expense is entailed in its removal.

144. Dangers to forests. - We have already called attention to the threatened destruction of our American forests by careless lumbering. (See 141.) This means not only the wholesale cutting of large areas of trees, but the lack of forethought which lumbermen show in leaving dead tree trunks and

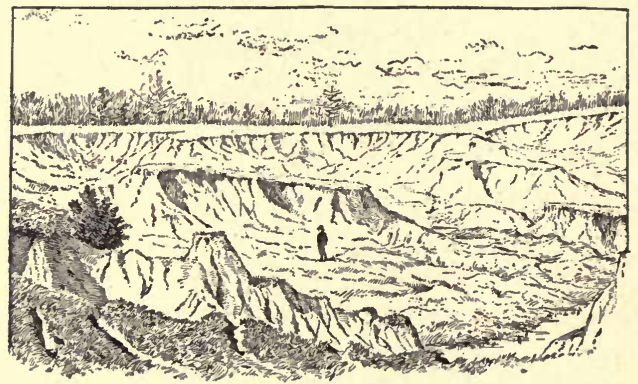

FIG. 69. - Excessive erosion of land caused by destruction of forests. - (Bailey.) branches to become the prey of destructive forest fires, which, when once started, devastate wide areas. The annual loss of property from this cause is conservatively estimated at more than one hundred million dollars.

This forest débris of dead tree trunks and branches also furnishes breeding places for insects, which, when hatched, prey upon healthy trees. Another source of danger, especially to young forest growth, comes from permitting large flocks of grazing animals like cattle and sheep to feed upon and trample down the small trees. If we are to preserve the 
remnants of our once vast forest resources, a public sentiment must be thoroughly aroused which will compel the passage and enforcement of conservation laws.

145. Necessity for reforesting and for forest protection. Surely, enough has been said to show the necessity for forest

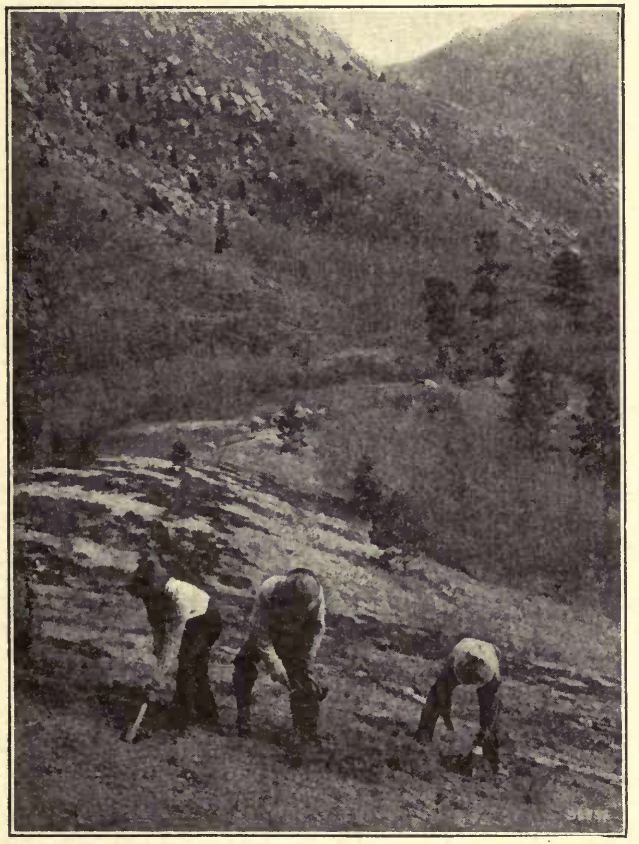

Fra. 70. - Planting young trees on hillsides. protection. Fortunately, laws are now being passed that will enable the National and some of the State governments to acquire large tracts of land for forest reservations. In many States these forest areas will protect the sources of large streams. There is great need of trained experts who will go through the forests, mark the trees which are mature enough to be cut, and decide which way they should fall to do the least damage to the younger growth. Again, large areas now devastated should be replanted with young forest trees, and this is also being done to a considerable extent. In many 
foreign countries, notably in Germany, the forests are so used that year after year they supply the requisite timber, and still continue to do their much needed work in conserving the rainfall. Such must be the policy in our country if we wish to escape most disastrous penalties that always result from forest destruction.

Another method of forest protection is that afforded by cutting trees in such a way as to form long, treeless strips of land known as fire lanes. Systems of telegraphic communication from one part of the forest reserves to another and fire wardens are necessary factors in efficient protection of forests.

\section{Fungi and their Relation to Human Welfare}

146. Fungi. - Thus far we have confined our attention to plants which are easily visible to the naked eye and which consist of roots, stems, and leaves. While we ordinarily think of these as the common plants, in reality the most common plant organisms are those which have neither roots, stems, nor leaves, and which in many cases are microscopic in size. The smallest and most numerous of these are known as bacteria, which are found all about us, in the soil, in the air we breathe, on the food we eat, and in the water we drink. Bacteria belong to a great group of plants called fungi. All fungi are characterized by the absence of chlorophyll, hence plants of this group cannot manufacture their carbohydrate food out of materials from the soil and air, but are dependent on foods made by green plants. More familiar to us, perhaps, than bacteria are the fungi known as mushrooms and toadstools, and the molds and mildews. Still other fungi are the yeasts, the rusts, and the smuts. Because of the enormous economic importance of many of these forms, we shall consider more or less in detail the structure, functions, and life-history of several of them. 


\section{A. Bacteria ${ }^{1}$}

147. Microscopical appearance and size of bacteria. Every one is familiar with the fact that if a bouquet of flowers is left for some time in a vase of water, the stems decay and disagreeable odors are given off. This is a common example of the action of bacteria, for all decay is due to the work of these organisms. When we come to examine the flower-stems or the putrid water, we find a slimy scum. If we put a drop of this scum on a slide, cover with a cover-glass, and examine with the highest powers of the microscope, usually we would see many different forms of living things. Some of them would probably appear relatively large, and these, as we shall see later (Chapter IV, "Animal Biology"), are single-celled animals. A closer examination will disclose countless numbers of very minute, colorless organisms; these are the bacteria. A careful study of many kinds of bacteria shows that they have several characteristic shapes (see Fig. 71) by means of which they can be roughly classified. Some are rod-shaped (like a firecracker), some are spherical, or egg-shaped, and still others are spiral-shaped. Each bacterium is a tiny bit of translucent protoplasm, inclosed in a cell wall of cellulose. Thus far no nucleus has been discovered in any kind of bacteria. Because of their cellulose walls, and because of their likeness to certain low forms of green plants, biologists now regard these organisms as plants rather than animals.

Some of the rod-shaped bacteria have one or more long, hairlike projections from the ends, called $c^{\prime} l^{\prime} i-a$, which give the germs still further resemblance to firecrackers. These cilia lash about rapidly, and thus drive the cells through the

${ }^{1}$ Because of the importance of bacteria in relation to sanitation, it may be found advisable to consider this whole topic in connection with human biology. Sections 148-154 will therefore be repeated in the book on human biology. 
water. The spiral bacteria roll over and over, and advance in a spiral path like a corkscrew. Other forms have rapid movements, but it is not known how they are accomplished.

It is very difficult to get any clear notion of the extreme minuteness of bacteria. It means but little to say that the rod-shaped forms are $\frac{1}{5000}$ of an inch in length. The imagination may be somewhat assisted if we remember that fifteen hundred of them arranged in a procession end to end would scarcely equal the diameter of a pin head.

148. Reproduction of bacteria. - When conditions are favorable, the production of new cells goes on with marvelous rapidity. The process is something as follows: The tiny cells take in through the cell wall some of the food materials that are about them, change this food into protoplasm, and thus increase somewhat in size. The limit is soon reached, however, and the bacterium begins to divide crosswise into halves. The mother cell thus forms two daughter cells
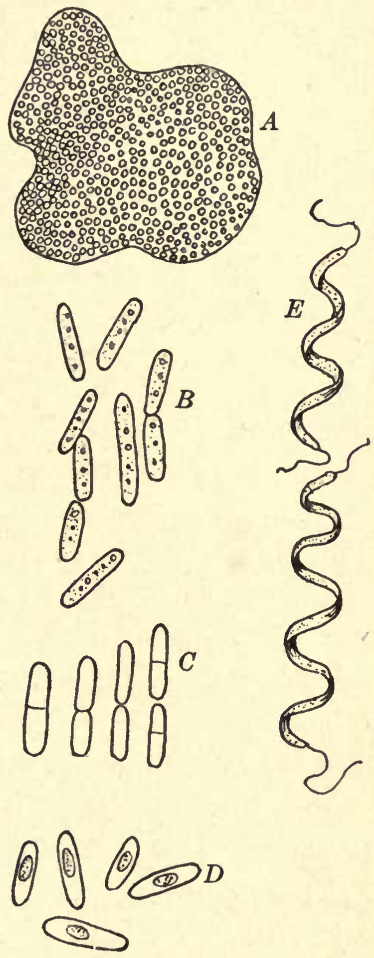

Fig. 71. - Various forms of bacteria.

$A$, a colony of spherical bacteria (coccus, plur. cocco) ; $B$, rod-shaped bacteria ( $b a-$ cillus, plur. bacilli) ; $C$, rodshaped bacteria dividing; $D$, rod-shaped bacteria, each containing a spore; $E$, spiral bacteria (spirillum, plur. spirilla) each with cilia.

by making a cross partition (cell wall of cellulose) between the two parts. (See Fig. 71, C.) If the daughter cells cling to- 
gether, a chain or a mass is formed. Oftentimes they separate entirely from each other. In either case the whole mass of bacteria is called a colony.

It usually takes about an hour for the division to take place. Suppose, then, we start at ten o'clock some morning with a single healthy bacterium. If conditions are favorable, there would be two cells at eleven o'clock, and by twelve o'clock each of these two daughter cells would form two granddaughter cells; the colony would then number four individuals. Should this process continue for twenty-four hours, or until ten o'clock on the day after the single bacterium began its race, the colony would number $16,777,216$ bacteria. "It has been calculated by an eminent biologist," says Dr. Prudden, " " that if the proper conditions could be maintained, a rodlike bacterium, which would measure about a thousandth of an inch in length, multiplying in this way, would in less than five days make a mass which would completely fill as much space as is occupied by all the oceans on the earth's surface, supposing them to have an average depth of one mile."

149. Necessary conditions for the growth of bacteria. Such startling possibilities as those suggested in the preceding section fortunately can never become realities, for the favorable conditions to which we have referred soon cease to exist. Bacteria, like all other living organisms, require food, oxygen, moisture, and a certain degree of warmth. Let any one of these conditions be withheld, and the cells either die or cease to be active. Sometimes, when food or moisture begins to fail, the protoplasm within each cell rolls itself into a ball and covers itself with a much thickened wall. This protects it until it again meets with conditions favorable for growth. The process we have been describing is known as

1 "The Story of the Bacteria," by Dr. T. Mitchell Prudden. G. P. Putnam's Sons, New York. 
spore formation; the tiny protoplasmic sphere is called a spore, and its dense covering a spore wall. (Fig. 71, D.) In this condition bacteria may be blown hither and yon as a part of the dust. They may be heated even above the temperature of boiling water without being killed. When at length they settle down on a moist surface that will supply them with food, the spores burst their thick envelope, assume once more their rod-shaped or spiral form, and go on feeding, assimilating, and reproducing their kind.

150. Relation of bacteria to soil fertility. - Having discussed somewhat the structure and functions of bacteria, we are now to consider the great importance of these microscopic organisms to human welfare. In the first place, were it not for their never ending activity, all life upon the earth would soon cease to exist. Let us see why this is so. When animals or plants die, their bodies fall upon the ground, and were these lifeless masses not taken care of, the whole surface of the earth would long since have been covered with a vast number of unburied or-

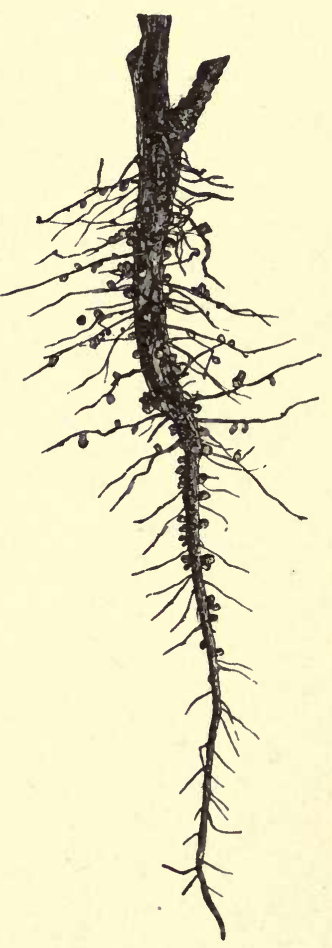

FIG. 72. - Roots of horse bean, showing numerous root-tubercles. - (Strasburger.) ganisms. All this dead material, however, as we have seen, is food for the countless bacteria; they cause it to decay, and thus decompose it into simpler chemical compounds that can soak into the earth and then be used in the nu- 
trition of the higher plants. And since plants are constantly taking from the soil the food materials which they need, this soil would tend to become less and less fertile were it not for the work of the bacteria that caused decomposition. This is the reason why rotting manure adds to the fertility of soil.

Again it has been proved that certain kinds of bacteria directly increase the amount of nitrogen compounds that are
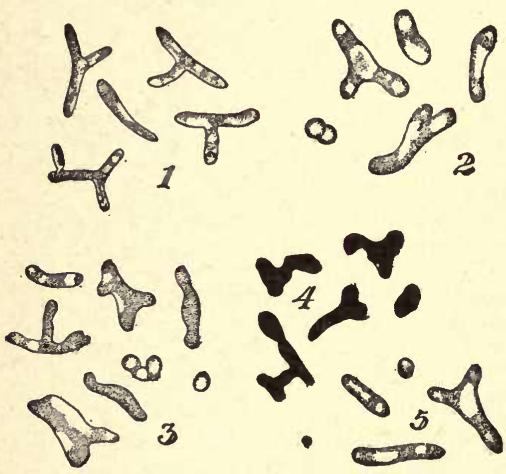

Fig. 73. - Bacteria from root-tubercles. (Duggar.)

so essential for plant growth. It has long been known that corn and other crops will grow better in soil that has just borne a crop of peas, beans, clover, or other members of the pea family. Within recent years an explanation of this fact has been found. When the roots of those pod-bearing plants are examined, small swellings are seen. These contain

multitudes of bacteria that are able to take the free nitrogen from the air, where it exists in such abundance, and store it away in the form of nitrates which are very important mineral matters needed by all crops. Since those bacteria can be put into soils that do not have them, it may be possible in the near future to restore much of the fertility which has been lost.

151. Relation of bacteria to the flavors of food. - Again, many of the flavors of food are due to the action of bacteria. Meats, for instance, when freshly killed, are tough and tasteless. If allowed to stand, however, by the decomposing 
action of bacteria these meats become tender and acquire their distinctive flavors. A similar action takes place when butter or cheese ripens, and the dairy industry has been perfected to such a degree that bacteria of certain kinds have been proved to give rise to definite flavors, and these bacteria can be produced in pure cultures for the dairymen.

152. Bacteria in the industries. - Without the help of bacteria the preparation of linen, jute, and hemp would be impossible. All these valuable products are plant fibers which are connected with woody materials so closely that they cannot be separated without first subjecting the stems of flax, hemp, and jute to a process of decay in large tanks of water. Moisture and warmth induce the rapid growth of germs, and this process loosens the tough fibers so they can be separated from the useless parts of the plant.

The change of alcohol into vinegar is caused by bacteria. Likewise in the preparation of indigo other forms of bacteria are all important.

153. Bacteria as the foes of man. - Unfortunately, however, there are certain germs that find favorable conditions for growth only in living animal tissue. Thus the bacterium of consumption grows in the lungs, the germ of diphtheria in the throat, and the bacteria that cause typhoid fever in the intestines. These disease-producing germs are called by Dr. Prudden "man's invisible foes." Yet wonderful progress is being made in the fight against them. We have learned how to check the ravages of cholera, typhoid, and diphtheria, and even consumption is found to be a preventable disease. Further discussion of bacteria will be found in several of the subsequent chapters. ${ }^{1}$

${ }^{1}$ For laboratory work on bacteria, see Chapter II, "Human Biology." Also consult Peabody's "Laboratory Exercises in Anatomy and Physiology" (1902), pp. 100-107. 


\section{B. Yeast (Optional)}

154. Microscopical appearance and size of yeast. - A small piece of a cake of compressed yeast, mixed in a spoonful of water, forms a milky fluid that is much like so-called bakers' or brewers' yeast. If we examine with the microscope a bit of this mixture in the same way in which the bacteria were studied, we find that it consists of innumerable bodies of minute size. These are yeast cells. Each cell is more or less egg-shaped, and is composed of color-

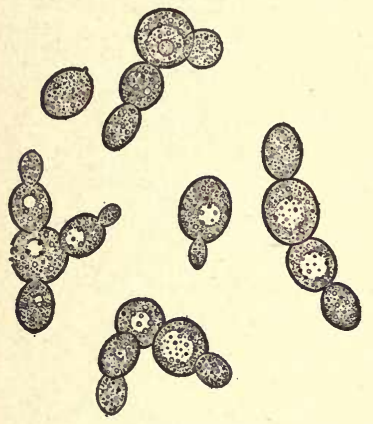

less protoplasm inclosed within a wall of cellulose. By the use of special stains, a nucleus becomes visible. (The spherical dots seen in fresh yeast cells are known as vacuoles and are filled with a colorless. liquid.) Yeast, like bacteria, is regarded as one of the lowest forms of plant life.

155. Reproduction of yeast. - Most of the cells that we are looking at are not separate individuals, but are FIG. 74. - Yeast cells, showing strung together in little chains. This method of reproduction by budding. Nuclei are not shown. Clear spaces are vac- method of reproduction of yeast. When uoles.

there is a sufficient supply of food, moisture, and oxygen, and when the temperature is favorable, these living plant cells begin to feed and to grow. They soon reach their full size, and then the cell wall is pushed out at the side by the growing protoplasm. In this way a bud is formed. This continues to grow and soon becomes a daughter cell, closed off from the mother cell by a wall of cellulose. Meanwhile, one or more buds may be forming on the outside of the daughter cells. If all these cells cling together, a colony is formed which consists of a mother cell (largest in size), one or more daughter cells, and several tiny granddaughter cells. The individual cells are easily separated from one another. This method of reproduction is known as budding (Fig. 74). 
156. Changes caused by yeast. - A yeast mixture may be easily prepared for experimentation by pouring into a jar a cup of water, adding a spoonful of molasses, and a spoonful of the milky fluid made as described in $\mathbf{1 5 4}$.

If the jar with its contents is set aside in a warm place $\left(70^{\circ}\right.$ to $90^{\circ}$ F.) for a short time, it begins to "work," and bubbles of gas rise to the surface. At the end of several hours, we notice that the sweetness of the molasses is disappearing, that the mixture begins to smell sour, and that a sharp, biting taste is becoming evident. All these changes are caused by the growth of living yeast cells.

Now, what is the gas that is formed in this process, and what causes the changes in taste and odor? To answer these questions we must carry our experiments still further. When the mixture is " working "well, the bottle should be tightly closed with a rubber stopper, through which extends one arm of an inverted U-shaped tube. The other end of this tube should run over to the bottom of a test tube half-filled with limewater. The gas that has been rising through the yeast mixture now passes through the U-tube, and as it comes in contact with the limewater, the latter changes to a milky-white color. This proves that the gas formed during the growth of yeast is carbon dioxid.

After "working" a day or two, the yeast mixture will have a strong taste and odor. A part of it should then be poured into a glass Florence flask (commonly used in the chemical laboratory for boiling liquids), and the mouth should be closed by a rubber stopper. The short arm of a long delivery tube should be passed through this stopper. When the flask is heated gently, some of the liquid is changed to a vapor. If the delivery tube is cooled by covering it with cloths wet in cold water, the vapor condenses into a liquid, which comes from the end of the tube in drops. This operation we have been describing is known as dis-til-la'tion. In distilling a liquid, we first convert it into a vapor, and then condense this vapor into a liquid. After collecting a few spoonfuls, the liquid should be slowly distilled a second time. Then we obtain a colorless fluid that has the distinct smell and taste of alcohol. It burns, too, with 
a pale blue flame. And so we learn that yeast, as it grows in the molasses mixture, changes the sweet substances into carbon dioxid and alcohol, a process that is known as alcoholic fer-men-ta'tion.

157. Uses of yeast. - When bread is made, water (or milk), butter, salt, sugar, and yeast are added to flour. After the mixture has been stirred together, a sticky mass of dough is formed, which in a warm place begins to rise. This is due to the fact that the yeast cells change the sugar into alcohol and carbon dioxid. Bubbles of gas are thus imprisoned in the sticky dough. While expanding and seeking to escape, they make the solid mass porous. After the bread has risen sufficiently, it is kneaded in order to break up the large bubbles and in order to distribute the gas throughout the dough. When the bread is baked, the alcohol and carbon dioxid pass off into the air, leaving the bread light and digestible. These minute organisms are also of great commercial importance in the manufacture of alcohol and of all kinds of liquors. It is known that yeast cells are found commonly in the air. As different kinds of fruits ripen, they are usually more or less covered with yeast or its spores. When, therefore, grapes are gathered and their juice is pressed out, the sweet liquid is soon alive with the busy cells, and fermentation begins at once. In this way wines are produced. Cider is produced by the fermentation of apple juice.

In the manufacture of beer and of other malt liquors, barley is commonly used. The grain is soaked and allowed to sprout for a short time, until the starch is changed to grape sugar. The barley kernels are then killed by heat to prevent further changes, and the grain is then known as malt. When this is put into water, the sugar is extracted. Yeast is then added, and the mass ferments. The beer thus formed contains 2 to 5 per cent of alcohol.

Distilled liquors, or spirits, are obtained from wines and other fermented liquors by the process of distillation, the principles of which have already been explanned. Brandy is made by distilling wine, whisky is obtained from fermented corn and rye, and rum is manufactured from molasses. All of these liquors contain a large percentage of alcohol ( 40 to 50 per cent). 
158. Suggestions for laboratory work on yeast. - No. 62 . Students should examine the appearance of yeast cells under the low and high powers of the compound microscope. If time permits, the demonstration of carbon dioxid production and of distillation of alcohol might well be made. (See Peabody's "Laboratory Exercises," pp. 94-99, Henry Holt \& Co., New York City.)

\section{Bread Mold (Optional)}

159. Structure of bread mold. - If pieces of bread or cake be moistened, and placed in a dish, and covered with a bell-jar in the

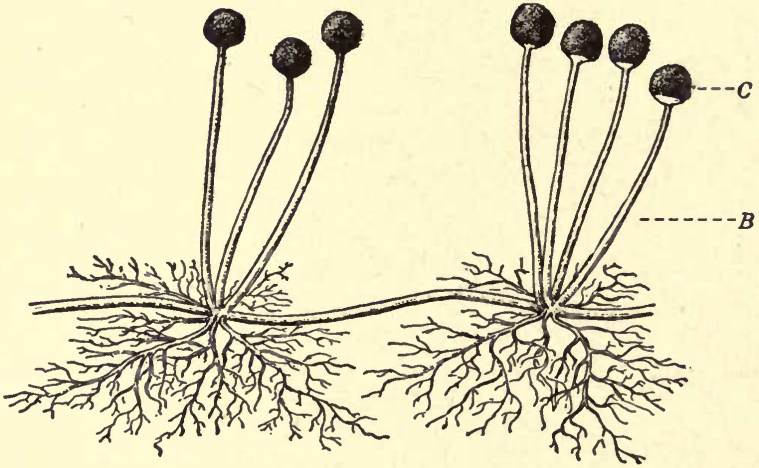

FIG. 75. - Bread mold, showing nutritive hyphæ $(A)$; reproductive hyphæ $(B)$; and spore cases $(C)$. - (Osterhout.)

dark, in a few days grayish patches will appear in places on the surface of the bread. This growth is due to the activity of one of the fungi, known as a mold, and will probably be the kind called bread mold. No care is required to produce the plant in quantities; on the contrary, as common experience shows, some pains must be taken by the housekeeper to prevent it from spoiling food.

When the bread mold is examined with a hand lens, it is seen to 
consist of a mass of fine interlacing threads called the mycelium. (See Fig. 75.) Single threads are known as hyphoe.

160. Reproduction and life history of bread mold. - Some of the hyphæ in their growth assume an upright position, and each of these at the upper end develops a little globular white mass or spore case. (See Fig. 75.) An examination with the high power of the microscope shows that the spore cases are filled with tiny cells known as spores. When the spores are ripe, the spore cases appear brown or black, they break open, and the spores are scattered. If these spores fall on food of some kind, such as bread, they begin to germinate, and each one produces another mass of threads with spore cases on erect hyphæ. In other words, the mold produces spores and the spores reproduce the mold. The spores of molds are in the air nearly everywhere, hence we see why molds appear so quickly on foods of various kinds, provided they are moist and in a warm place.

161. Nutrition in the fungi. - Molds, like other fungi, as we have already said, cannot manufacture their own food out of the materials obtained from the soil and air, but are dependent on foods made by green plants. Certain of the threads called the nutritive hypho form ferments which digest the food compounds found in bread or other substances on which the mold is growing, and then the digested food is absorbed, used in growth, and in the production of energy. Other threads develop the spore cases and so are called reproductive hyphas. Hence, it is evident that fungi, like all plants, carry on both nutritive and reproductive functions, but on account of the lack of chlorophyll are, like animals, dependent on the green plants for their supply of food.

162. Suggestions for laboratory work on bread mold. - No. 63. Sow bread mold as suggested in $\mathbf{1 5 9}$ in sufficient quantity to supply each two pupils with a piece of the moldy bread. Pupils should examine a specimen with a hand magnifier, describe the appearance of the mycelium and hyphæ bearing spores, and should then make a drawing to show these points. Some of the 
spore cases should be placed on a slide in water and covered with a cover glass. If the glass cover is tapped with a pencil, some of the spore cases will be ruptured. The preparation should then be examined with the high power of the compound microscope, and the ruptured spore cases drawn, together with a few of the escaping spores.

\section{Other Fungi (Optional)}

163. Mushrooms. - Mushrooms are forms of fungi which are often called "toadstools," especially if they are supposed to

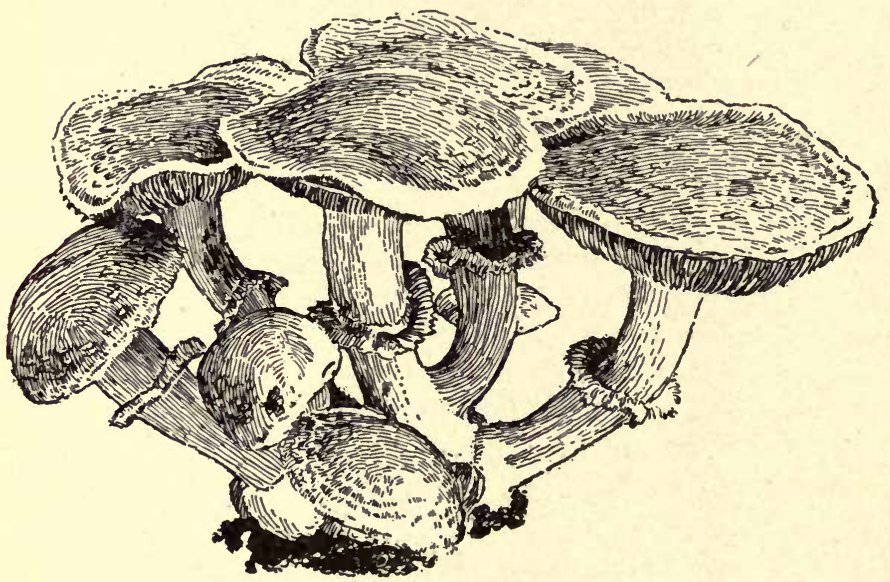

Fig. 76. - An edible mushroom.

be poisonous. All fungi of this kind should, however, be called mushrooms, since their structure and life history are similar. The conspicuous part of the plant, the umbrella shaped structure so familiar to all, is really the reproductive organ of the plant, the part that bears the spores (Fig. 76). The nutritive organs are a mass of threads (as in the mold) which lie beneath the surface, where they absorb the foods from some decaying material in the soil to give rise to the reproductive body. 
As indicated above, many mushrooms are poisonous, but a few kinds are known to be edible. ${ }^{1}$ Mushrooms are not especially nutritious; that is, they cannot take the place of the cereals and other staple foods, but they serve to add to the variety of materials which are more valuable for their flavoring qualities than for the quantity of nutriment they contain. Commercially the cultivated mushroom is of considerable importance, especially in Europe. Paris is said to be the center for the sale of this product. In the year

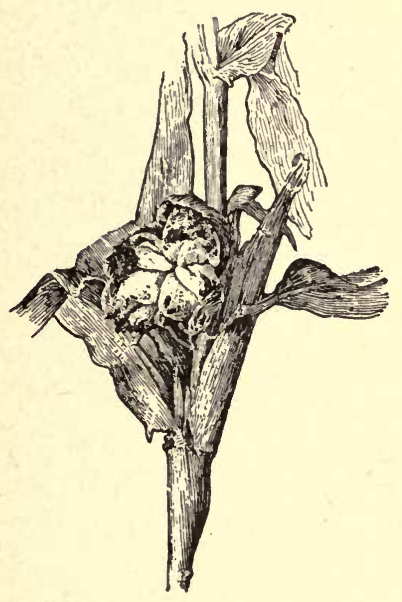

FIg. 77. - Corn smut on an ear of corn.

1901 it was estimated that $10,000,000$ pounds of cultivated mushrooms passed through the markets of Paris. In this country the mushroom is of commercial importance only in the regions of the larger cities.

164. Rusts and smuts. - The fungi known as rusts receive their name from the rusty appearance in an early stage of their growth which they cause on the stems and leaves of plants which they attack. The cereals, wheat, oats, barley, and rye, are the crops which this fungus injures most. In the case of wheat, half of the crop or even more may be destroyed.

The very suggestive name of smut is given to another fungus which affects all the cereals named above, and corn as well. In the case of corn, this plant often affects the ears as well. The name is probably given on account of the appearance of the mass of black spores. If one touches these spores, especially those of corn smut, with the finger, and then rubs the finger on some white paper or

${ }^{1}$ So many deaths are caused by using poisonous instead of edible mushrooms that it is never safe to eat wild forms until they have been identified by an expert. 
cloth, a sooty mark is left. The damage done by smuts is very considerable. In case of the corn crop alone it has been estimated that a yearly loss of 20 per cent of the crop, or $\$ 20,000,000$, is caused thereby, and in the other cereal crops the loss is even greater. It should be mentioned in closing this discussion that the rusts and smuts are only two of a large number of fungous diseases that affect plants. 


\section{CHAPTER X}

\section{PLANT CLASSIFICATION}

\section{Common Methods of Classification}

165. Herbs, shrubs, and trees. - One way of classifying the common plants with which we are most familiar is that of calling them either herbs, shrubs, or trees. This classifica-

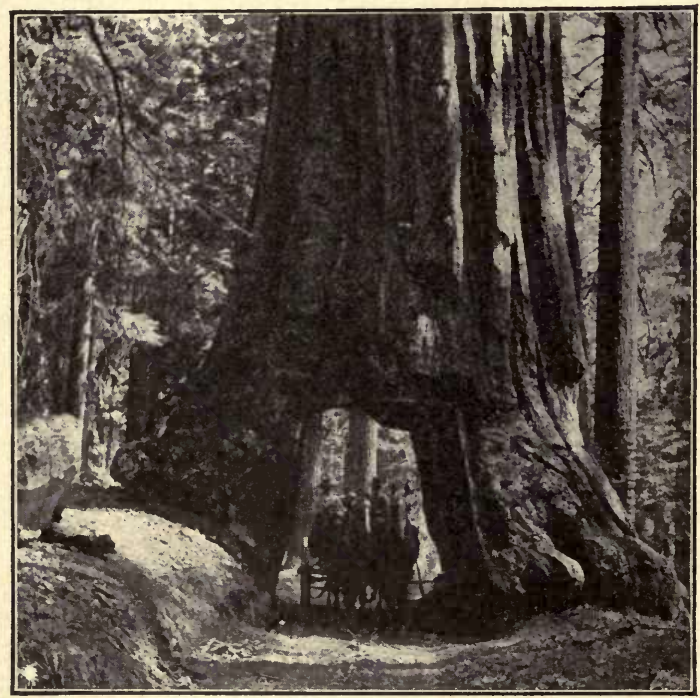

Fig.78. - Base of one of the giant trees of California. - (Tarr and McMurry.)

tion is based upon the general similarity in size, form, and texture of the plants which are assigned to each group. Thus when we think of a tree we have in mind a plant which, when 


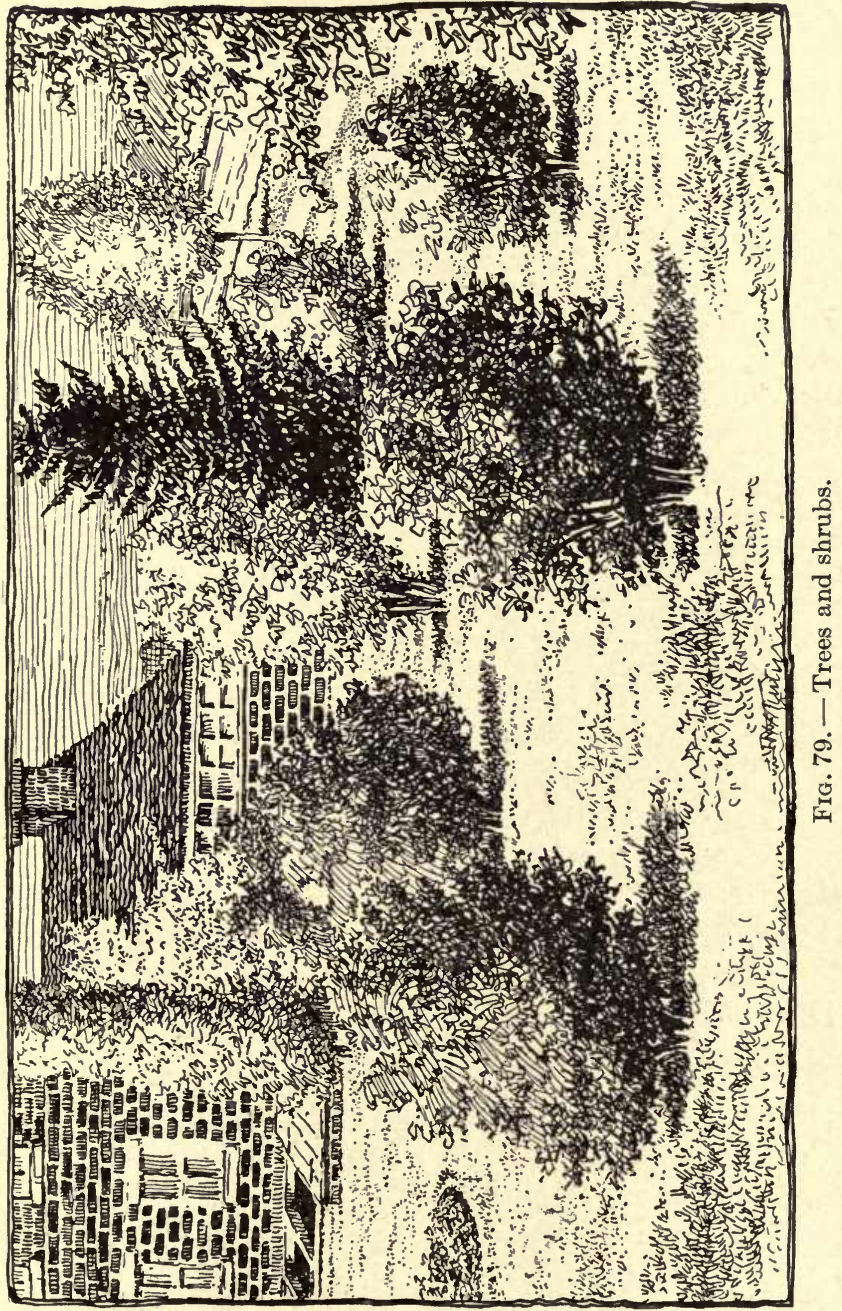


mature, is of large size, with a single woody trunk and branches. This trunk may extend up nearly to the top of the tree, as in the case of the pines and spruces, or some distance above the ground the trunk may divide into branches, as is true in the elms and maples.

A shrub, on the other hand, is usually of smaller size even when fully grown than is a tree; it commonly does not have a single trunk, but several woody stems which often start from the ground level, as in the lilac, rose,

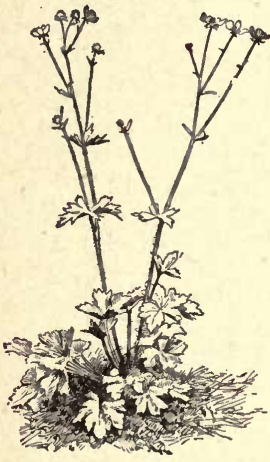

FIg. 80. - An herb. and witch hazel. Both shrubs and trees are alike in that their stems and branches do not die down to the ground at the end of the season.

An herb, as the term is used in plant biology, is a plant of relatively small size, with comparatively little woody material in its stem, which dies down to the ground level at the close of the season. Such are beans, corn, and morning glories. The roots or underground stems of some herbs - for example, dahlias, carrots, and parsnips remain alive ready for growth the next year. These facts suggest another method of classifying plants, namely, as :

166. Annuals, biennials, and perennials. - When a plant attains its maturity in one season's growth and then dies, as do beans, corn, and morning glories, such a plant is called an annual. Many plants which have fleshy roots, like the beet, carrot, and parsnip, do not produce flowers and seeds until the second year. During the first season after the seed is planted the food manufactured in the leaves passes down the plant and is stored beneath the ground. At the end of the season 
the stems and leaves above ground die; but if this root remains in the ground or is planted the next season, stems, leaves, and flowers develop rapidly, and finally seeds are

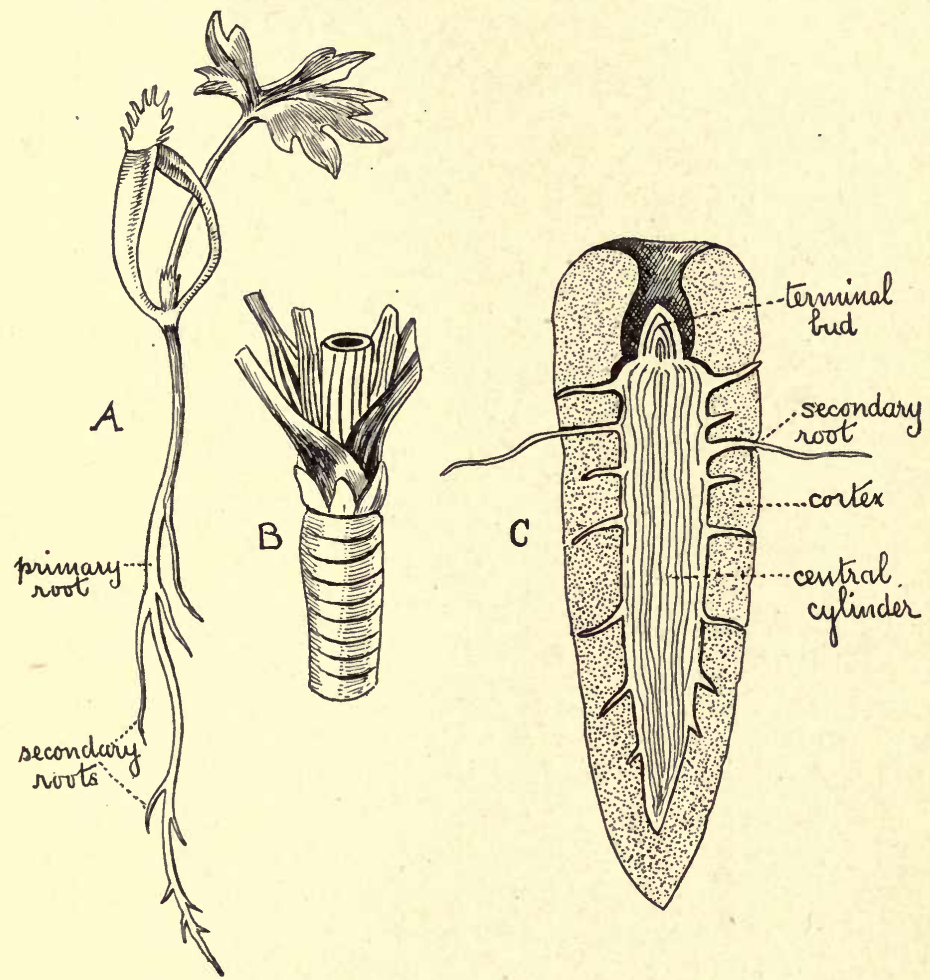

Fig. 81. - Carrot. $A$, young seedling; $B$, enlarging root early in season; $C$, section of enlarged root late in season.

formed, the food stored up the preceding season being drawn upon for the development of these parts. Plants which have a life history like this and which live for two years only are 
called biennials (Latin, $b i=$ two + annus $=$ year). Perennials are plants that live year after year. Hollyhocks and dahlias, for instance, store food in fleshy roots year after year, while the parts above ground die, as in the case of beets and carrots. Other perennials, like trees and shrubs, lose only their leaves at the end of each season.

167. Deciduous and evergreen trees and shrubs. - Trees and shrubs may be classified as evergreen or deciduous. Since the leaves of pines, spruces, and hemlocks remain green and attached to the stem during the winter, these plants are known as evergreens. Certain shrubs (rhododendrons, arbutus, and wintergreen, for example) also keep their green leaves throughout the winter, and so in a sense they may be regarded as evergreens. Maples, elms, and horse-chestnuts, on the other hand, shed their leaves in autumn; they are therefore said to be deciduous (Latin, $d e=$ from + cadere $=$ to fall).

168. Field work on plant classification. Optional. - No. 64 . If possible, teachers should accompany their pupils on a field trip, point out and name the plants best adapted for a study in classification, using perhaps an outline like the following:

\begin{tabular}{|c|c|c|c|c|c|c|c|c|c|}
\hline $\begin{array}{c}\text { Name of } \\
\text { Plant }\end{array}$ & Herb & Shrob & Tree & $\begin{array}{l}\text { Simple } \\
\text { Leaves }\end{array}$ & $\begin{array}{c}\text { COM- } \\
\text { POUND } \\
\text { LEAVEs }\end{array}$ & $\begin{array}{c}\text { OPPO- } \\
\text { SITE } \\
\text { LEAVES }\end{array}$ & $\begin{array}{c}\text { Alter- } \\
\text { NATE } \\
\text { LEAVES }\end{array}$ & $\begin{array}{c}\text { DECID- } \\
\text { UOUS }\end{array}$ & $\begin{array}{l}\text { EvER- } \\
\text { GREEN }\end{array}$ \\
\hline Rose & & $\mathrm{X}$ & & & $\mathrm{X}$ & & $X$ & $\mathrm{X}$ & \\
\hline
\end{tabular}

\section{Scientific Method of Classification}

169. Scientific classification of plants. - The various methods of grouping plants that we have thus far considered do not indicate real relationships among plants, for these schemes call attention only to certain superficial resemblances 
and differences in form, or size, or habit. True scientific classification seeks to bring together into a given group all the plants that are closely related to each other; that is, those which are probably descended from common ancestors. In the first place, all plants are divided into two great groups known as seed-producing plants, and spore-producing plants. The first is the group to which most of our attention has thus far been given, and it embraces the herbs, shrubs, and trees, with which we are most familiar. We should bear in mind, however, that many plants, like the palm and rubber plant, which do not produce flowers in our climate, develop flowers, fruits, and seeds when they are growing in their natural home. Other plants with inconspicuous flowers - for example, grasses, elms, and pines - also belong to this great group of seed-producing plants.

\section{Sub-kingdom I, Seed-producing Plants (Optional)}

170. Gymnosperms and angiosperms. - Seed-producing plants are still further subdivided into two groups. The first group includes all plants like the pines, hemlocks, and spruces, in which the seeds are not produced in ovaries, but at the base of scale-like leaves which are usually grouped together to form cones; hence the name cone-bearing plants, which will apply to the common forms. The whole group is known as gymnosperms (from Greek meaning naked seeds).

Plants like beans, cucumbers, and pansies, on the other hand, develop their seeds in ovaries, and these and all other plants of this type constitute the second of the two sub-divisions, which is known as the angiosperms (from Greek meaning having a vessel for seeds).

171. Monocotyledons and dicotyledons. - Again, the seed-producing plants may be classified according to the number of cotyledons found in the seed. The corn, gladiolus, and lilies, for example, have seeds with one cotyledon, and hence these are known as monocotyledons (Greek, mono $=$ one + cotyledon). Beans, peas, and maples, on the other hand, have two cotyledons and are therefore 
called dicotyledons (Greek, $d i=$ two + cotyledons). There are other striking characteristics which distinguish these two groups of angiosperms, which have already been brought out in our laboratory work, as the following table will show:

Number of cotyledons Veining of leaves Stem structure

Number of stamens and other parts of flower
Monocotyledons

(Corn, tulip, gladiolus)

one

parallel

woody bundles scat-

tered through pith

based on plan of three or some multiple of three

\section{Dicotyledons}

(Bean, horse-chestnut, pansy) two

netted

bark, wood in distinct annual rings, pith in center

based on plan of five or some number other than three

172. Plant families. - Continuing our classification of the angiosperm group still further, we find that the dicotyledons are subdivided into over one hundred and sixty so-called plant families, some of which are the violet family, the buttercup family, the rose family, and the pulse family. This grouping into families is based largely upon flower structure, and so it sometimes happens that an herb and a tree belong to the same family. For example, the pea, bean, and the locust tree all belong to the pulse family, since they have flowers closely resembling each other.

173. Plant genus. - Again, each of the 160 or more families is made up of a varying number of more closely related plant groups, each of which is known as a genus. The rose family, for example, has fourteen genera, some of which are the pear genus, the rose genus, and the cherry genus.

174. Plant species. - Once more, each genus consists of a varying number of species, the members of which resemble each other 
very closely. The pear genus consists of the pear species, the apple species, and the crab apple species. Species, again, may be still further subdivided into varieties, in which the plants are more closely related (e.g. Baldwin and Greening varieties among apples). And finally a species (or variety) is made up of individual plants, that resemble each other in all essential respects.

\section{Sub-kingdom II, Spore-producing Plants (Optional)}

\section{A. Ferns}

175. The fern plant. We turn now from a discussion of seed-bearing plants to a consideration of those plants which never produce flowers or seeds. As a representative of the highest group of plants without seeds, we will study the ferns. The majority of ferns grow in damp, shady places, and among the common kinds we may name the brake, the maiden-hair, and the rock fern. In any one of these ferns the parts above ground which are true leaves are known as fronds. The main axis of each frond runs throughout the leaf, and to each side are attached the leaflets, which may or

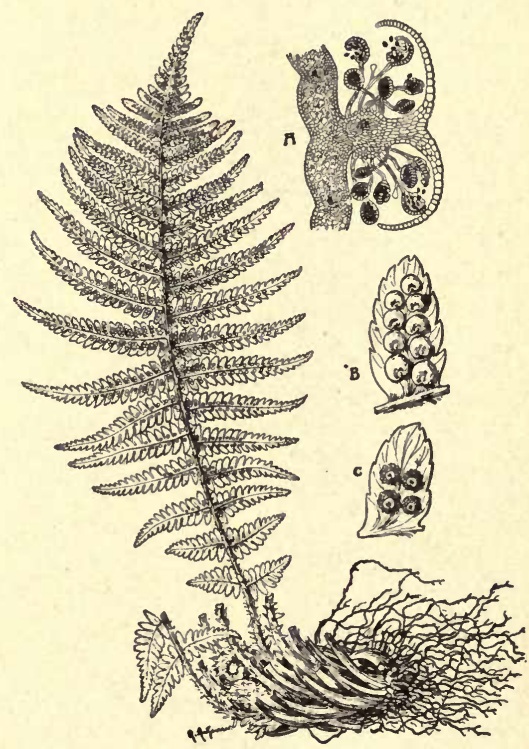

Fig. 82. - Fern plant (Aspidium), showing roots, rhizome, and frond: $A$, 'section of fruit dot (sorus), showing spore cases, some of which are ejecting their spores; $B$, portion of a leaflet, showing unripe fruit dots ; $C$, portion of a leaflet, showing ripe fruit dots. - (Strasburger.) 
may not be still further subdivided. Hence, a fern leaf is usually compound, and is strikingly graceful in its appearance.

Beneath the ground the fronds grow from a horizontal stem called the rhizome, which is more or less enlarged for food storage, depend-

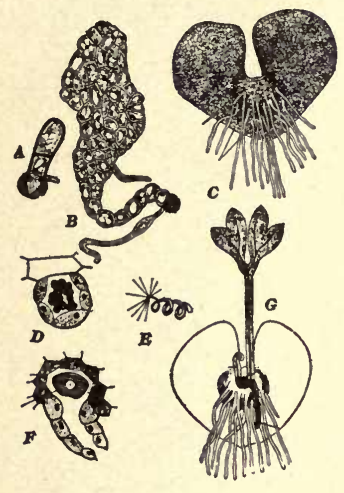

FIG. 83. - Development of fern plant.

$A$, a germinating fern spore; $B$, a later stage in germination : $C$, a full-grown prothallus, showing rhizoids, antheridia (or spermaries, and archegonia (or ovaries; $D$, section of antheridia (or spermary); $E$, a sperm cell ; $F$, a section of archegonia (or ovary) containing an egg-cell; $G$, young fern plant developing from a fertilized eggcell in an ovary, still attached to the heart-shaped prothallus. - (Parker.) ing on the kind of fern. To this rhizome are attached the roots by which the plant is supplied with soil-water. The fern plant, therefore, like seedbearing plants, has all three kinds of nutritive organs (roots, stem, and leaves), and carries on carbohydrate manufacture in the green fronds, storing away the food in the rhizome, since the leaves die to the ground each year. The following spring the tiny leaves push up through the ground from the underground stem, unrolling and spreading their leaflets from the base to the tip.

176. Fern spores. - On the under surface of some of the leaflets of the ferns named above are little dots which are often brown. These are known as fruit-dots (sori). Each fruit dot, if examined with a microscope, is found to consist of several smaller objects known as spore-cases. ( $B, C$, Fig. 82.) When these tiny spore cases are ripe, they open, often with considerable force, and eject a powder, each particle of which is called a spore. (Fig. 82, A.) Each spore consists of a single cell.

177. Fern prothallus. - When the spores fall to the ground and conditions are favorable, they start to germinate, and each finally produces a small green, heart-shaped plant known as a prothallus (Fig. 83, C). The prothallus, though tiny, consists of a great 
number of cells, some of which form tiny outgrowths from the under surface like root-hairs (called rhizoids), which anchor the prothallus to the soil and aid in securing food materials.

On the under surface likewise of each prothallus, in the region of the rhizoids, are minute organs, circular in appearance, known as antheridia (spermaries), in which are produced a large number of sperm-cells (Fig. 83, $D, E$ ). At a little distance from the antheridia, near the notch in the prothallus, are found other somewhat elongated bodies called archegonia (ovaries). In each of these there is developed a special cell known as the egg-cell (Fig. 83, F).

178. Fertilization of the egg-cells. - When the sperm-cells are ripe, the antheridia or spermaries are ruptured, and the spermcells make their way by a curious twisting motion toward the openings on the archegonia. A single sperm-cell moves down the tube of each archegonium, and penetrates the egg-cell, and the two nuclei unite in the process of fertilization. (See 91.) From the fertilized egg-cell develops a fern plant composed of many cells of various kinds, which are all derived from the fertilized egg-cell.

179. Alternation of generations. - Thus we see that in the lifehistory of the fern plant we have two distinct generations. The first is the ordinary fern plant, which is familiar to all, and which is known as the asexual generation or spore generation, because the spores formed on the fronds produce the next generation (prothallus) without fertilization or the union of two kinds of cells. The second generation, the prothallus, is the sexual generation, because, as we have seen, it can only produce a fern plant from the fertilized eggcell. In plants like the fern, in which an individual (fern) produces another plant (prothallus) unlike itself, and this in turn gives rise to a plant like the original (fern), we have so-called alternation of generations.

180. Suggestions for the study of the fern. - No. 65. If this topic is suggested for study, pupils should be encouraged to collect their own material, noting the surroundings or habitat of each kind of fern. They should describe the location, form, and color of each of the nutritive organs, and of the fruit dots, and draw the 
entire fern. Each student should study a prothallus with a hand magnifier, making an enlarged drawing of the same to show its form and the position and shape of the rhizoids, antheridia, and archegonia. A demonstration of the steps in the life history may well be shown from charts.

\section{B. Mosses}

181. The moss plant. - A second group of flowerless plants includes the mosses. In general, mosses are smaller plants than the ferns, but like them are usually found in damp, shady places. If one examines a moss plant when it is " in fruit," a slender stem will be seen projecting from the leafy part below. At the upper end of this slender stem, a covered cup-like structure is evident (Fig. $84, A, k)$. This cup, or capsule as it is called, is filled with tiny dustlike particles, which when examined with a compound microscope prove to be cells. They are called spores. The spores are reproductive bodies similar to those produced in the spore cases of ferns.

182. The moss protonema. - When these bodies are ripe, the capsule opens and discharges some of the spores, which fall to the ground and soon begin to grow, forming at first an elongated cell (Fig. 84, $H$ ) which later divides, giving rise to two cells. This process continues until a slender, green, thread-like mass is formed, with many branches. This thread-like mass is called the protonema (Fig. 84, G). Some of the branches produce buds which finally grow into the leafy structure which we know as the moss plant (Fig. 84, $B, A$ ).

183. The sexual generation of the moss. - At the top of some moss plants at certain seasons of the year, in the midst of the rosette of green moss leaves, may be found tiny flask-shaped organs, the archegonia (ovaries) (Fig. 84, F). At the base of each of these organs is produced an egg-cell. Sometimes in the same moss plant, and sometimes in another, are to be found club-shaped organs called antheridia (spermaries) (Fig. 84, E). In the antheridia are produced sperm-cells (Fig. 84, D). At the proper time the spermcells make their way into the archegonia, and when a sperm-cell 
reaches an egg-cell they fuse, the two nuclei unite, and a fertilized egg-cell is formed. This fertilized egg, by the process of growth and

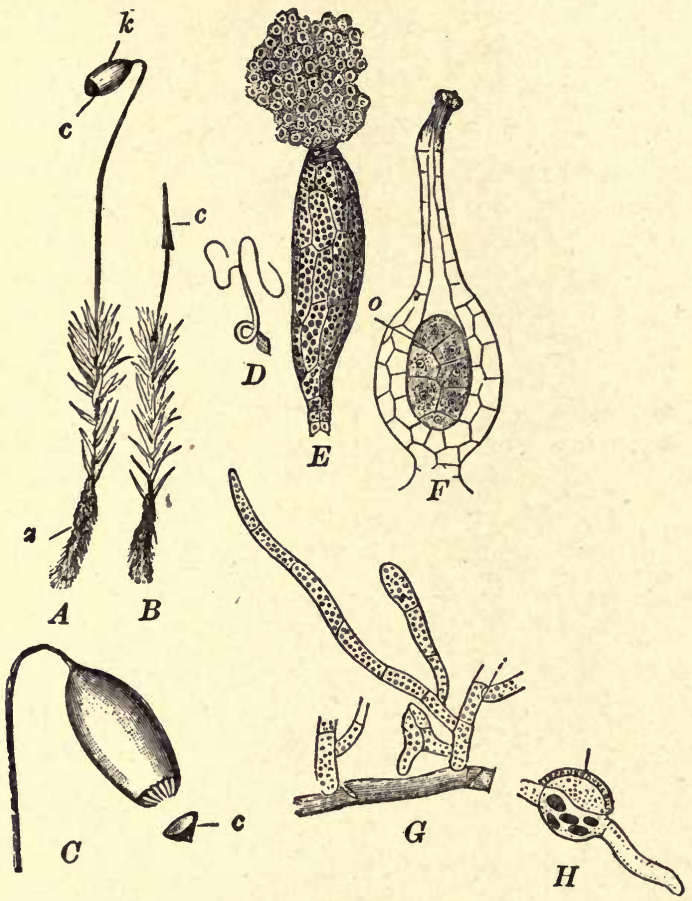

Fig. 84. - Development of a moss plant.

$A$, moss plant with spore case $(k)$ having a lid $(c) ; z$, rhizoids : $B$, young moss plant; $C$, enlarged view of spore case, with lid $(c)$ detached; $D$, single sperm-cell ; $E$, spermary with escaping sperms; $F$, ovary with dividing egg-cell $(o) ; G$, branching protonema ; $H$, spore germinating to form protonema.

cell division (Fig. $84 ; F, o$ ), finally forms the slender stalk with the capsule and spores at the end of it like that referred to in $\mathbf{1 8 1}$ (Fig. 84, $A, C$ ). 
184. Alternation of generations in the moss. - The protonema and the leafy shoots with their antheridia and archegonia are known as the sexual generation because it is this plant that produces eggs and sperm-cells which must unite before the egg can develop into the spore-bearing plant. The slender stalk with the capsule at the end which is produced by the fertilized egg-cell is called the asexual generation, since the spore-bearing plant can reproduce without the union of two kinds of cells. The spore-bearing plant is dependent on the leafy plant for all its food. In the fern, on the other hand, it is evident that the spore-bearing plant and the plant producing eggs and sperms are entirely independent plants. In both of these groups of seedless plants, however, there is an alternation of generations.

185. Suggestions for the study of mosses. - No. 66. The teacher should secure plenty of material for the demonstration both of the plants with spore cases and if possible the plants with archegonia and antheridia. On account of its size the pigeon wheat moss is desirable. The material may be collected and dried, since both generations are not likely to be obtained at the same time of year. If spore cases are on hand, the work might then be done when the sexual plants can be secured in a fresh condition. The pupil should describe and draw the leafy moss plant. The location of archegonia and antheridia should be stated. Then the spore-bearing plant should be described, together with the relation to the sexual plant which produced it, and the spore case opened to show the spores. The two plants should then be drawn and labeled.

\section{Alga}

186. Spirogyra. - Any one who has ever been in parts of the country where ponds or very slowly moving bodies of water abound must have noticed either at the bottom or on the surface of the water a green, slimy mass. It is so frequently found on the surface that it is called " pond scum." If one examines a small portion of this mass even with the naked eye, one will see that it consists of a great number of interlacing threads. When looked at with the compound 
microscope each of these threads is seen to be a series of cells joined end to end. All the cells are practically the same in shape and structure, however, so that a study of one will make clear the structure of all.

Inclosing each cell there is a thin cell wall. The first structures one is likely to notice within the cell are the chlorophyll bodies. In the pond scum known as Spirogyra the chlorophyll is arranged in spiral bands, and it is this which has given the plant its name (Fig. 85, B). In other forms the chlorophyll is differently arranged,
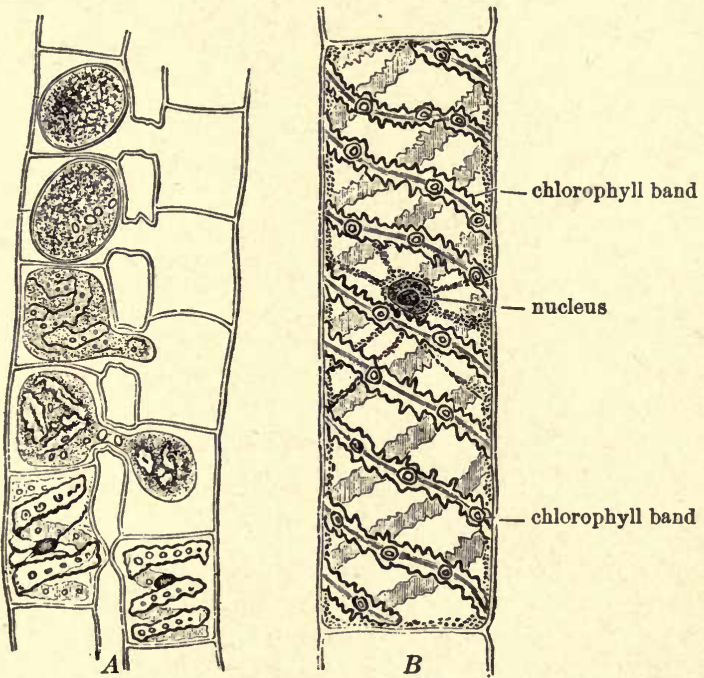

Fig. 85. - Spirogyra. - (Strasburger.)

$A$, two conjugating threads of Spirogyra; $B$, single cell of Spirogyra.

sometimes in star-shaped masses, one in each half of the cell, and sometimes diffused throughout the cell. If a little iodine is added to the specimen when it is being examined under the microscope, a nucleus may be distinguished near the center of each cell (Fig. 85, $B$ ). In the cell-body and nucleus the protoplasm appears as a clear and almost transparent mass. 
The thread or filament continues to increase in length by the growth and division of certain individual cells that compose it. At the close of the season most of the filaments perish, but some of them undergo peculiar changes. The bands of chlorophyll lose their definiteness, the protoplasm becomes massed, tiny outgrowths from the sides of the cells occur, and these continue to extend till they meet similar outgrowths from a neighboring filament (Fig. 85, $A$ ). These outgrowths unite, and thus a tube from one cell to the other is formed. The contents of one cell pass through to another, and the two masses fuse. A thick wall forms about the united mass and the old cell walls decay and fall away, leaving these thick-walled zygospores on the bottom of the pond. In the spring the protoplasm within each of these zygospores begins to grow, breaks through the thick wall, and proceeds to form a new filament by cell division. The formation of the zygospores is known as conjugation; it is a kind of sexual reproduction, though the two cells taking part in the process are the same in appearance.

If one observes pond scum on a sunny day, bubbles will be seen escaping from the mass. A test of this gas proves it to be oxygen, and as we should expect, it occurs in connection with the process of carbohydrate manufacture the same as in other green plants. In fact it has been proved that these simple plants manufacture foods, digest, assimilate, respire, and reproduce as do the higher plants we have studied. The differences, then, between a simple plant like Spirogyra and a bean plant or an oak tree are mainly those of structure and adaptations for the performance of functions which are largely common to both. Indeed, it is evident that every cell of the Spirogyra is in contact with the water, from which all the substances needed are obtained by absorption. Hence, any special adaptations for securing food materials or of giving off wastes, such as are found in higher plants, are unnecessary.

187. Suggestions for the study of Spirogyra. - No. 67. It is desirable that pupils should see the "pond scum" in its habitat, even if they do not collect material for work. The escape of bubbles may be noticed at this time or in the laboratory. The mass should be described as to color and "feel," and the fine threads noted by 
floating the mass in a saucer of water. A filament should then be studied under the microscope, and the parts of a single cell described, and several cells should be drawn. If fresh zygospore material can be obtained, this should also be studied, and the parts described above noted and drawn; otherwise charts or pictures may be used.

188. Pleurococcus and other algæ. - Another and still simpler form of plant life is known as Pleurococcus. It may be readily obtained from the trunks on the north side of large trees. It appears as a very thin green layer closely adhering to the bark. If a little of this material is scraped off and placed under the compound microscope, it will be found that it is made up of a large number of tiny circular green cells which adhere to each other more or less, since in the process of reproduction one cell

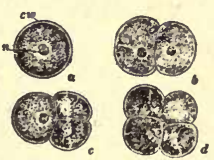

Fig. 86. - Pleurococcus. - (Sedgwick and Wilson.) divides to form two, each of which is considered to be an individual plant. Thus the whole mass is made up of a large number of one-celled plants.

The Spirogyra and Pleurococcus are only two of a large number of simple plants known as algæ. "They differ widely in form, but none of them develop roots, stems, or leaves. Among the most common algæ are the marine forms known as sea weeds, of which there are many kinds.

189. Suggestions for the study of Pleurococcus. - No. 68. As indicated above, material for the study of Pleurococcus may be easily obtained by removing pieces of bark from trees having a considerable quantity of this plant on their surface. If collected in a dry season, the bark should be placed under a bell-jar with sufficient water to make the air moist, and allowed to stand for several days. The place in which the Pleurococcus is found should be described, and also the appearance of a mass of the plants. Single cells should then be studied under the high power of the compound microscope, and the cell and its contents described and drawn.

\section{Fungi. (See Chapter IX, 147-166.)}




\section{Summary of a Classification of the Plant Kingdom}

Division I - Spore-producing plants.

Sub-division 1-Fungi (including bacteria, yeast, molds, mushrooms, rusts, smuts).

Sub-division 2-Algce (including Spirogyra, Pleurococcus, and sea weeds).

Sub-division 3-Mosses and their relatives.

Sub-division $4-$ Ferns and their relatives.

Division II - Seed-producing plants.

Sub-division 1-Gymnosperms (including pines, spruces, hemlocks).

Sub-division 2 - Angiosperms, composed of :

Class I - Monocotyledons (e.g. corn, lilies, gladiolus).

Class II - Dicotyledons - composed of 160 or more families, one of which is

Rose family - composed of 14 genera, one of which is the Pear genus - composed of 3 species, one of which is the Apple species, of which there are many varieties, e.g. Baldwin, Greening, etc. 


\section{APPENDIX I}

\section{LABORATORY EQUIPMENT}

The laboratory. - It is very desirable that a definite room or rooms be set apart for work in biology, since at least a minimum equipment is essential, and this cannot be transferred from room to room without considerable loss of efficiency. While it is desirable to have tables or at least flat-topped desks of good size, satisfactory
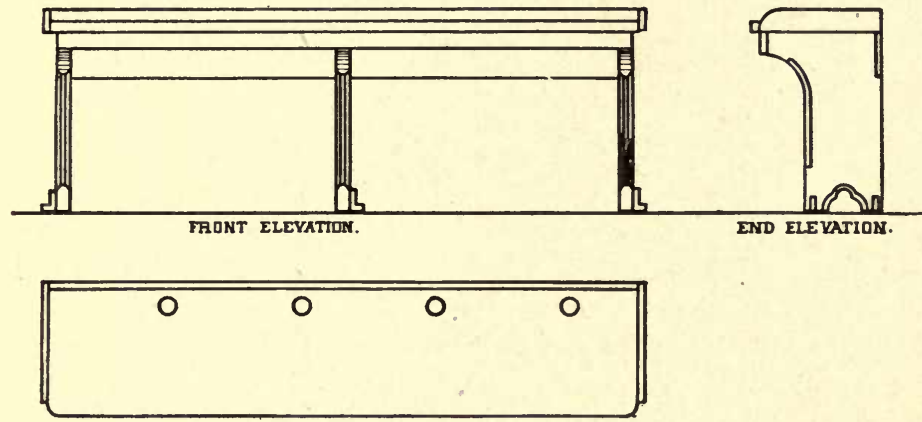

ToP.

Fig. 87. - Plans for a laboratory table.

laboratory work can be done in an ordinary class room if it is well lighted. The laboratory should be supplied with a demonstration table and gas connection if possible, with sink and running water, and a broad shelf should be placed in front of the windows for supporting growing plants and aquaria, and for use in demonstrations with the compound microscope. Ample closet room should be provided in which to store apparatus and supplies, so that they may be kept free from dust. 
In case it is possible to equip a room with laboratory tables the following type is suggested. In the first place the laboratory tables should be firmly fixed to the floor, and arranged so that the light comes from the left side, and if possible also from the back of the room. The desk tops should be 30 inches from the floor and 20 inches wide, and should be made of maple or other hard wood. The length of each table will of course depend upon the dimensions of the room, but if possible no more than three pupils should be provided for at a single table. Each student should have at least 30 inches of the table space. (Fig. 87.)

"The finish of the laboratory table tops is a matter of importance, since it must be such as to protect the wood from damage, and keep it clean and smooth. Many prefer a black finish, to obtain which the following method gives good results.

"Make up solutions:

(1) Copper sulphate $\left(\mathrm{CuSO}_{4}\right)$. . 625 grams Potassium chlorate (KClO ) . . . 625 grams Water to make . . . . . 5 liters

(2) Anilin oil . . . . . . . . 300 grams Hydrochloric acid $(\mathrm{HCl})$. . . 450 grams Water to make . . . . . . 2500 liters

"Apply solution (1), followed immediately by (2) several times, until the wood becomes a dark green, allowing the applications to dry each time. The darker the tone reached, the better. The wood must then be washed thoroughly with soap and hot water applied with a brush. This is necessary in order to remove the superfluous salts. The table is finished with oil and will then be dead black." 1

The advantages of the dull black finish are these: (1) there is little reflection of light from this kind of surface into the eyes of the pupils; (2) the black surface furnishes an admirable background for many objects of study ; and (3) the tops are not injured by water, acids, or other chemicals.

Experience has shown that unless the laboratory must be used

1 From Lloyd and Bigelow's "The Teaching of Biology.", 
as an assembly room for a division at the beginning and close of school, drawers and shelves beneath the desk are of little real use, and often become mere receptacles for laboratory débris, unless they are provided with locks. It is usually far safer and more satisfactory to collect drawings, magnifiers, pencils, etc., at the close of the period, and to distribute materials as they are needed during the next period. If this work is properly systematized and the assistance of pupils is made use of, very little of the laboratory time is lost in this way.

Seats fixed to the floor, likewise, are of great advantage. The authors have found that the best seat for this purpose is the Chandler chair, which is furnished by the American Seating Company, 19 West 18th St., New York City. It has a strong iron base, which can be screwed to the floor, and the chair seat turns on ball-bearings through an are of 180 degrees. The price of the chair is $\$ 2$.

Apparatus and chemicals. - The following lists of apparatus and chemicals are suggested as a minimum equipment for a class of 24. Most of the items can be purchased from any one of the following dealers:

Bausch and Lomb Optical Co., Rochester, New York.

Kny-Scheerer Co., 404 West 27th St., New York City.

O. T. Louis, 59 Fifth Avenue, New York City.

Quantity Apparatus and Glassware Estimated Price

1 Compound microscope, with $\frac{2}{3}$ - and $\frac{1}{6}$-inch objectives, double nose-piece, 1 inch eye-piece, and revolving disk-diaphragm . . . . . . . . $\$ 30.00$

24 Magnifiers, doublets, $1 \frac{1}{2}$-inch focus . . . . . . 16.20

1 Harvard trip-scale balance . . . . . . . . 6.00

12 Evaporating dishes, 3 inches diameter . . . . . 1.50

1 2-quart agate double boiler .. . . . . . . 1.50

2 Alcohol lamps or . . . . . . . . . . . $\quad .50$

2 Bunsen burners (if gas is available) . . . . . . $\quad .40$

$3 \mathrm{ft}$. Rubber tubing (heavy) to fit Bunsen burners . . $\quad .60$

144 Slides, plain, $1 \times 3$ inches . . . . . . . . $\quad .80$ 
$1 \mathrm{oz}$. Cover glasses (rounc') . . . . . . . . . . $\$ .70$

12 Sloyd knives . . . . . . . . . . . 2.25

24 Forceps (heavy) . . . . . . . . . . 5.00

12 Dissecting scissors . . . . . . . . . . 2.25

50 Handles (adjustable) for dissecting needles . . . 2.00

100 Needles for handles . . . . . . . . . . $\quad .25$

1446 -inch test tubes . . . . . . . . . . . . 1.50

12 8-inch test tubes, hard glass . . . . . . . 1.50

2 Chemical thermometers (Fahrenheit and Centigrade scale on same) . . . . . . . . . . . 2.00

1 Lactometer . . . . . . . . . . . 50

1 Radiometer . . . . . . . . . . . . . 1.10

2 Iron ring-stands (3 rings) . . . . . . . . . 1.10

2 Pieces wire gauze $(4 \times 4$ inches $)$. . . . . . . .08

2 Pieces asbestos $(4 \times 4$ inches $)$. . . . . . . $\quad .07$

6 Glass stirring rods . . . . . . . . . . . $\quad .10$

$25 \mathrm{ft}$. Glass tubing, $5 \mathrm{~mm}$. outside . . . . . . . .30

$10 \mathrm{ft}$. Rubber tubing to fit glass tubing . . . . . $\quad .70$

12 Thistle tubes (medium size) . . . . . . 1.00

12 Beakers, 150 to 250 cc. . . . . . . . . . . 1.50

3 Bell jars 2 feet high and 10 inches in diameter . . 14.40

3 Bell jars about 8 inches high and 10 inches in diameter . . . . . . . . . . . 5.00

1 Bell jar, open top, 8 inches high and 8 inches in diameter . . . . . . . . . . . 2.00

1 piece Sheet rubber 2 feet square (should be kept in lightning fruit jar when not in use) . . . . 1.50

24 Lightning fruit jars (1 quart) . . . . . . . 3.00

6 Flasks, 250 cc. . . . . . . . . . . . . . 1.00

36 Petri dishes, 4 inches in diameter . . . . . 6.00

1 Cylindrical graduate, $1000 \mathrm{cc}$. . . . . . . 1.35

1 Cylindrical graduate, 100 cc. . . . . . . . 40

6 Tall glass cylinders (1000 cc.) . . . . . . . 1.75

1 Box slide labels . . . . . . . . . . . . . . . . . . . .

1 Box labels, $2 \times 3$ inches . . . . . . . . . . $\quad .18$

1 Steam sterilizer, copper bottom, 18 inches high . . 6.00 
50 8-ounce wide-mouthed bottles

50 4-ounce wide-mouthed bottles

24200 cc. narrow-mouthed bottles with ground glass stoppers . . . . . . . . . . . . . 2.60

100 Vials with corks, 3 inches high, 1 inch in diameter . $\quad 2.75$

100 Corks to fit 8-ounce wide-mouthed bottles . . . 1.00

100 Corks to fit 4-ounce wide-mouthed bottles . . . $\quad .75$

100 Corks to fit 6-inch test tubes . . . . . . . * $\quad .40$

10 Rubber stoppers with 2 holes to fit 250-cc. flasks . . $\quad .45$

10 Rubber stoppers with 1 hole to fit 6-inch test tubes . $\quad .30$

2 Insect spreading boards . . . . . . . . 1.00

QUANTITY

Charts and Preparations

Estimated Price

11 Jung plant charts (pansy, horse-chestnut, tulip, linden, potato, carrot, pea, 'Spirogyra, mold, fern, moss)

$\$ 13.20$

1 Teachers' Botanical Aid, 28 charts, containing 300 drawings (Western Publishing House, Chicago, Ill.)

11 Jung animal charts (fish (external), fish (internal), frog, Amœba, Paramecium, crayfish, bee, butterfly, cricket, finch, duck) . . . . . . . .

4 Leuckhart animal charts (grasshopper, bee, butterfly, metamorphosis of frog) . . . . . . . 8.00

1 Model of heart and lungs (dissectible), natural size

1 Model of digestive system on panel, natural size

1 Model of circulatory system on panel, natural size .

1 Articulated human skeleton, clutch standard

1 Life history of butterfly

6.00

1 Life history of honey bee . . . . . . . 5.00

1 Life history of frog . . . . . . . . 5.00

1 Life history of fish . . . . . . . . 5.00

1 Half skeleton of fish (glass case) . . . . . . 3.00

1 Half skeleton of frog (glass case). . . . . . 4.00 
8 Microscopical slides of plant tissue (cross section and longitudinal section of young root, cross section and longitudinal section of stem one year old, cross section of hydrangea leaf, epidermis of leaf, separate wood cells, ducts, conjugating Spirogyra)

5 Microscopical slides of animals (Amœba, Paramecium, frog's blood, human blood, mouth parts of bee)

$\$ 3.50$

QUANTITY

List of Chemicals

Estimated Price

$2 \mathrm{lb}$. Hydrochloric acid

$\$ 1.00$

$1 \mathrm{lb}$. Nitric aci

$1 \mathrm{lb}$. Ammonia

$1 \mathrm{oz}$. Iodine

$5 \mathrm{oz}$. Potassium iodide

$1 \mathrm{lb}$. Ether.

$1 \mathrm{lb}$. Caustic soda

Small tube red litmus paper

1 gal. 95 per cent alcohol

$10 \mathrm{lb}$. 40 per cent formalin

8 oz. Glycerin

1 oz. Pepsin

$1 \mathrm{lb}$. Peptone

1 oz. Taka diastase

$1 \mathrm{lb}$. Salt

$1 \mathrm{oz}$. Phosphate of lime .

$1 \mathrm{lb}$. Grape sugar

$\frac{1}{2} \mathrm{lb}$. Cooking soda

$1 \mathrm{lb}$. Copper sulphate

$1 \mathrm{lb}$. Rochelle salt

1 jar Beef extract .

$1 \mathrm{lb}$ Agar

$\frac{1}{2}$ lb. Powdered sulphur

$1 \mathrm{lb}$. Potassium chlorate 
$\frac{1}{2}$ lb. Manganese dioxid . . . . . . . . . . $\$ .35$

$1 \mathrm{lb}$. Granulated zinc . . . . . . . . . . . $\quad .25$

1 lb. Absorbent cotton . . . . . . . . . . . $\quad .35$

6 Small candles . . . . . . . . . . . . $\quad .10$

$1 \mathrm{lb}$ Marble pieces .......... . .10

5 lb. Plaster of Paris . . . . . . . . . . . $\quad .10$

5 oz. Potassium cyanide . . . . . . . . . . $\quad .10$

1 oz. Ferric chloride . . . . . . . . . . . . .05

$1 \mathrm{lb} . \quad$ Corn starch . . . . . . . . . . . . . 10

$\frac{1}{2} \mathrm{lb}$. Arrow root starch . . . . . . . . . . . $\quad .15$

$1 \mathrm{oz}$. White egg albumen ... . . . . . . . 12

$1 \mathrm{oz}$. Powdered carmine . . . . . . . . . . 40

$1 \mathrm{oz} . \quad$ Gluten . . . . . . . . . . . . . . 15 


\section{APPENDIX II}

\section{ORDER OF TOPICS}

The following order of topics, with time assignment for each, has been found by the authors to be satisfactory:

I. Course begun in September and completed in June.

1. The general structure of plants (organs of a plant) 2 lessons

2. Reproduction in plants.

$a$. Structure and adaptations of flowers

b. Structure and adaptations of fruits, including fruit and seed dispersal . . . . . . 5 lessons

3. Plant propagation.

$a$. Seeds and their development into plants . ' 6 lessons

$b$. Conditions essential for the growth of plants . 2 lessons

4. Cellular structure of plants, including fertilization of flowers . . . . . . . . . . 5 lessons

5. Composition of living and lifeless things.

a. Elements, compounds, oxidation, with definitions . . . . . . . . . . . . 10 lessons

b. Composition of food substances, with tests for each . . . . . . . . . . 8 lessons

c. Manufacture of food substances by plants . . 5 lessons

6. Osmosis and digestion . . . . . . . 5 lessons

7. Adaptations of the nutritive organs of plants.

a. Structure and adaptations of roots . . . . 5 lessons

b. Structure and adaptations of stems . . . . 3 lessons

c. Structure and adaptations of leaves . . . . 4 lessons

8. Respiration and the production of energy in plants 4 lessons

9. Plants in their relation to human welfare. 
a. Some uses of plants to man . . . . . 3 lessons

b. Forests and forest conservation . . . . . 3 lessons

10. Single-celled animals . . . . . . . . . 5 lessons

11. Fish (and frog, if this form is taught) . . . . 14 lessons

12. The general structure of the human body . . . 3 lessons

13. Microörganisms and their relation to human welfare .

10 lessons

14. Nutrients and their uses . . . . . . 7 lessons

15. Stimulants, narcotics, and poisons . . . . 10 lessons

16. Digestion of the nutrients . . . . . . 7 lessons

17. Circulation of the nutrients . . . . . . 6 lessons

18. Respiration and the production of heat and power in man . . . . . . . . . . . . 7 lessons

19. Additional topies in hygiene . . . . . . 9 lesssons

20. Birds . . . . . . . . . . . . . 5 lessons

21. Insects . . . . . . . . . . . 15 lessons

II. Course begun in February and completed in January.

1. Composition of living and lifeless things.

$a$. Elements, compounds, oxidation, with definitions

10 lessons

$b$. Composition of food substances, with test for each

c. Manufacture of food substances by plants .

8 lessons

5 lessons

2. General structure of plants, including cellular structure .

5 lessons

3. Osmosis and digestion . . . . . . . . 5 lessons

4. Adaptations of the nutritive organs of plants.

a. Structure and adaptations of roots . . . . 5 lessons

$b$. Structure and adaptations of stems . . . 3 lessons

c. Structure and adaptations of leaves . . . 4 lessons

5. Respiration and the production of energy in plants 4 lessons

6. Reproduction in plants.

$a$. Structure and adaptations of flowers

15 lessons

b. Structure and adaptations of fruits, including fruit and seed dispersal .

5 lessons 
7. Plant propagation.

$a$. Seeds and their development into plants . . 6 lessons

$b$. Conditions essential for the growth of plants . 2 lessons

8. Plants in their relation to human welfare.

a. Some uses of plants to man . . . . . . 3 lessons

b. Forests and forest conservation . . . . . 3 lessons

9. Insects . . . . . . . . . . . . 15 lessons

10. Birds . . . . . . . . . . . . . . 5 lessons

11. Fish (and frog, if this form is taught) . . . 14 lessons

12. Single-celled animals . . . . . . . . 5 lessons

13. The general structure of the human body . . 3 lessons

14. Microörganisms and their relation to human welfare . . . . . . . . . . . . 10 lessons

15. Nutrients and their uses . . . . . . 7 lessons

16. Stimulants, narcotics, and poisons . . . . 10 lessons

17. Digestion of the nutrients . . . . . . . . 7 lessons

18. Circulation of the nutrients . . . . . . 6 lessons

19. Respiration and the production of heat and power in man . . . . . . . . . . 7 lessons 20. Additional topies in hygiene . . . . . 9 lessons 


\section{APPENDIX III}

\section{BIOLOGY NOTE-BOOKS}

Method of Recording Laboratory Observations. - In preparing note-book records of laboratory observations or experiments, home work, or field trips, the teacher should insist, so far as possible, that pupils give in clear, concise English a complete account of the work that has been done. Students should be careful to state the purpose of the experiment, and describe the preparation of the experiment. He should indicate whether the work was done by himself or by some one else. The results observed should be sharply distinguished from the conclusions derived from observation. Pupils might well use as paragraph titles the section titles printed in heavy face type (e.g. Carbon, Oxygen, etc.). On pp. 182-183 are two accounts of the same experiments that were photographed from the note-books of two different pupils. The method of writing up an experiment shown in Fig. 88 is suggested for accounts that are written in the laboratory; that in Fig. 89, for accounts written at home.

Drawings. - In making drawings pupils should be supplied with sharp-pointed pencils that are relatively hard. Clear outline drawings should be insisted upon, and shading should as a rule not be encouraged (Figs. 90, 91). The general title of the sheet of drawings should be placed at the top of the sheet. When there are several drawings on the same sheet, the general title should be placed at the top, and the special title of each should be written just below the individual drawing. In labeling, the dotted leaders may run in any direction (see pp. 184-187), but they should not cross each other. The labels, however, should all be written parallel to the top margin 
182

PLANT BIOLOGY

Dec.11,19"1 margaret Cutler - IV.

9 Carbon (symbol, C) -Home trot

1. a. Cmadepome charcoal by lightengalong splinter of wood and blowing out the flame. "Charcoal w nearly jere carlow."

b. Carbon ssa solid. Stisales black

c. Thesesperment proves that word is party composed of carbon

2. a. held the tie, of the charcoal in a hor flame and it glowed.

b. Some of the carbon dicrepreared.

c. Carbon well burn.

3. Carbons a black e, solid, and et burns.

4. A held my hand over tho glowing charcoal wethmyeyes closed, d could tell the carbon was still burning because it sent forthkeat.

10. Oxygen (symbol, 0)-Laboratorydlemonstration.

- as examined bottle of oxygen.

b. Oxygensisagas.

c. It has no color.

2. a. Same charcoal (carbon) wacheated until it glowed and was thrust in to a bottle oxygen. et bust into flame.

b. Carbon burns better in pours oxygen thaw in avs.

FIG. 88. - Specimen page from a note-book. 
APPENDIX III

183

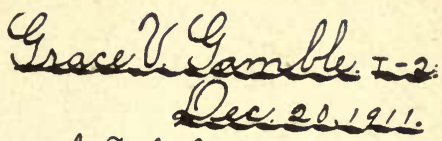

Cheonsal Composition of Lifeless and Living e Things

Carbon (SspoblC). I lit match and watched it burn. After a while d blew the flame out. The result was that the match stick was black, and shriveled up. Therefore, from this esperi mental conch ide that w odes fart by con posedefcarbon. Carbon is a solidmase Our teacher held a piece of carbonic a hot flame, and d noticed that the carborngradmall disappeared and ashes were left. it is black; these are the three characteristicuthat d have learned about carbon. A pupil put her hand over a piece of lighted carbon with her eyes closed, she could tell that it was still burning by the heat.

Oxygen (Symbol O):- When ourteachel performed the experiment, I found that oxygen is a gas, and it is colorless. Then our teacher heated a

FIG. 89. - Specimen page from a notebook. 
184

PLANT BIOLOGY

Mabelle Taker I-2

Study of the Coin Deed ling

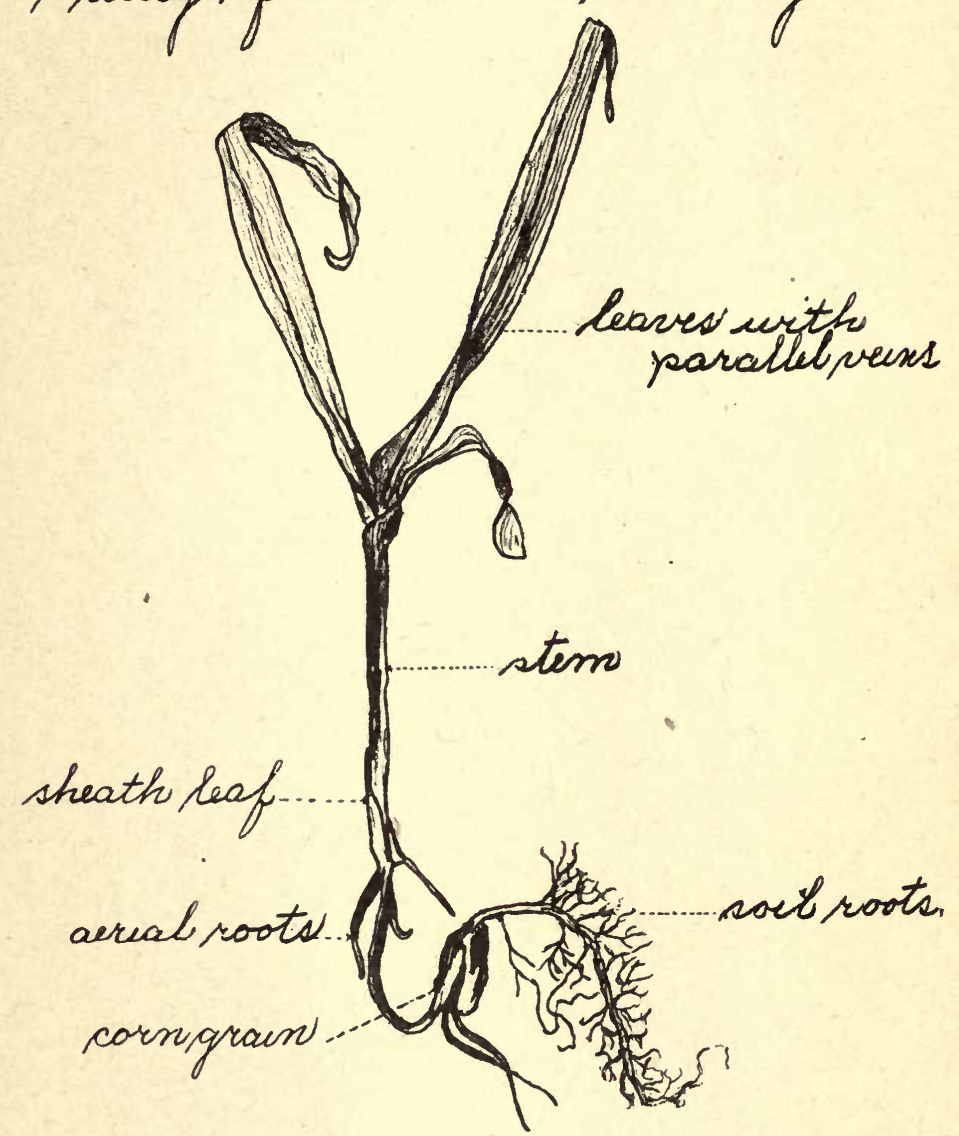

FIG. 90. -Drawing of an advanced stage of the corn seedling. 
of the sheet. If the drawings are made on separate sheets of paper about the size of a page in the note-book, the sheets may be collected, criticized, and rated, and then, if the left-hand margin of about an inch is folded, the drawings can be fastened in the note-book by pasting this narrow flap.

The following directions for guiding pupils in the preparation of their note-books have been found by the authors to be of great assistance.

1. In the upper right-hand corner of the outside front cover of your note-book write your name, division (i.e. grade and section), and the classroom in which you meet at 9 A.M. thus:

\section{JOHN S. JONES, I-8 (or IA) \\ Room 416}

Across the middle of the front cover write Biology Noteвоок.

2. Cover your note-book with manila paper, and on the front cover put the information called for in 1 above. Be sure to keep your note-book covered.

3. Write your name, division, and classroom in the upper righthand corner of the first page of your note-book. Leave the rest of this page blank for the teacher's ratings and comments.

4. Number each page of your note-book.

5. On each of the pages draw a vertical line about an inch from the left margin. Always leave this marginal space for the teacher's comments.

6. Begin each new subject on a new page, writing its title on the first line. The first composition or notes should commence on page 5 , the preceding pages being reserved for index.

7. Write your compositions or notes in ink on both sides of the page.

8. Indent about an inch the first word of each paragraph. All other lines should begin at the left margin line. It is 
suggested that the paragraph titles used in the laboratory studies be employed and that they be underlined (e.g. Parts of a Leaf).

9. Make sure that your statements in each paragraph or in your notes are sufficiently full and clear to be readily intelligible to one who knows nothing of the subject.

10. In your compositions or notes be careful to make clear what you yourself did, what you saw, what you heard, and what you read. Accounts of experiments may often be written in four paragraphs as follows: object of experiment; preparation of experiment; result of experiment; conclusion from experiment.

11. If, on account of absence, it is necessary that work be copied, inclose such account in quotation marks, and write at the end of such quotation the name of the pupil from whom the account was copied.

12. Every correction indicated by the teacher should be made by the student as soon as the note-book is returned.

13. Every student who wishes to do so can produce a first class note-book, neat in appearance, and at least relatively free from mistakes in spelling, punctuation, and grammar.

\section{Marks used in the Correction of Biology Papers}

$\mathrm{cp}=$ mistake in use or in omission of capital letter.

$\mathrm{cl}=$ meaning not clear.

$\mathrm{gr}=$ mistake in grammar.

$\mathrm{n}=$ composition is lacking in neatness.

I $=$ error in paragraphing.

$\mathrm{p}=$ mistake in punctuation.

$\mathrm{r}=$ repetition of word or idea.

$\mathrm{sp}=$ error in spelling.

$\mathrm{w}=$ word improperly used.

$?=$ doubt as to the truth of the statement.

()$=$ words in parenthesis are to be crossed out.

$\wedge=$ some oumission. 
APPENDIX III

187

Clara Lang $\pi-10$
gov 10, 1911

Structure of the Ir ag

aperies

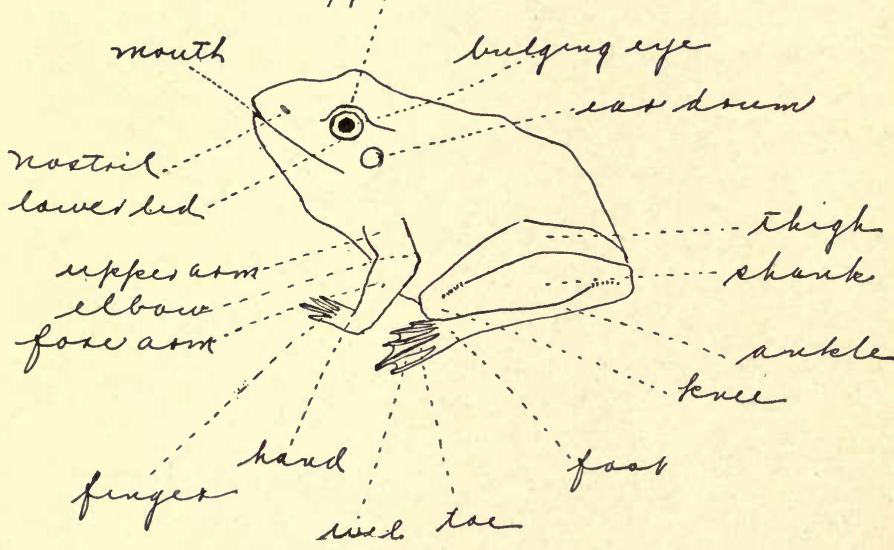

Fig. 91. - Drawing of side view of frog. 


\section{APPENDIX IV}

\section{REVIEW TOPICS IN PLANT BIOLOGY}

You should be prepared to give a good oral recitation on each of the following topics. If you are not sure of any of the facts called for, write down the topic or topics, and ask your teacher at the beginning of the next recitation how to obtain the information.

\section{A. Composition of Lifeless and Living Things.}

1. Chemical element: definition; examples with symbols of each; characteristics of each (i.e. whether it is solid, liquid, or gas; color, odor, and taste; ability of each to burn or to cause burning).

2. Oxidation: definition; chemical element necessary; compound formed by the oxidation of elements; evidences of oxidation.

3. Chemical compound: definition; examples; test for two of them, with characteristics of each (as in 1 above).

4. Food substances: kinds; chemical composition of each; test for each ; examples of foods containing each in abundance.

5. Manufacture of food substances by plants: 'proofs of the necessity of sunlight, chlorophyll, and carbon dioxide for carbohydrate manufacture; proofs of the excretion of oxygen in carbohydrate manufacture; manufacture of proteins.

B. General Structure of Plants.

1. Parts of a plant; organs and functions.

2. Structure of plant cells; protoplasm; assimilation, growth, and cell division. 


\section{Osmosis and Digestion.}

1. Proofs that water and grape sugar will pass through a membrane ; definition and law of osmosis.

2. Proofs that starch and protein will not pass through a membrane; digestion of starch ; definition of digestion; digestive ferments.

D. Adaptations of the Nutritive Organs of Plants.

1. Roots: gross structure; structure of a root-hair ; functions of roots; adaptations of roots.

2. Stems: gross structure of a woody stem; functions of stems; adaptations of stems; changes in stems during growth.

3. Leaves: gross and microscopical structure; functions of leaves; adaptations of leaves.

E. Respiration and the Production of Energy in Plants.

1. Energy: examples in plants; proof that heat energy is developed in growing seedlings; transformations of energy ; source of energy ; oxidation as a means of liberating energy.

2. Respiration: definition; proof of the necessity of air for plants and of the production of carbon dioxide by plants.

F. Reproduction in Seed-producing Plants.

1. Floral envelopes: names of the parts of each floral envelope; position and general description of the floral envelopes in the flowers studied; functions of each of the floral envelopes.

2. Essential organs: name, number, position, and parts of each of the essential organs; general description and functions of the parts of each of the essential organs.

3. Pollination.

a. Self-pollination : definition; devices to prevent it in flowers studied.

b. Cross-pollination: definition; devices to make it possible in flowers studied; agencies which secure cross-pollina- 
tion; comparative vigor of plants from seeds resulting from cross-pollinated and from self-pollinated flowers.

4. Fertilization.

a. Cellular nature of pollen and ovules ; - germination of pollen grains.

b. Structure of ovule.

c. Process of fertilization; production of the embryo.

5. Fruits.

a. Structure of each of fruits studied; definition of a fruit; classification of fruits.

$b$. Necessity for seed-dispersal ; agencies by which seed-dispersal is brought about; adaptations of fruits and seeds to secure dispersal by each of these agencies.

c. Adaptations for protecting seeds of unripe edible fruits; adaptations for protecting seeds of ripe edible fruits.

\section{G. Plant Propagation.}

1. Bean seed and its development into a seedling: markings on seed; their cause or function; seed covering; position and kinds of stored food; description of parts of embryo; parts of the plant which develop from the parts of the embryo; breaking of seedling through the soil.

2. (Optional.) Corn grain and its development into a seedling: description of the parts of the embryo; position and kinds of stored food; breaking of seedling through the soil ; various parts of the plant which develop from each of the parts of the embryo.

3. Definitions: seed, seedling, germination, seed coats, micropyle, hilum, embryo, cotyledon, plumule, hypocotyl, endosperm, primary and secondary roots.

4. Experiments to show -

$a$. Function of endosperm of corn grain.

b. (Optional.) Relation of water and temperature to germination.

5. (Optional.) Other methods of plant propagation: grafting; slips, runners, and layers; tubers; bulbs. 
6. Conditions essential for the growth of plants: five essential conditions ; conditions of soil favorable for growth; methods of soil improvement.

7. (Optional.) Struggle for existence and its effects: Variation among plants; numbers of seeds produced by plants; struggle for existence among plants; survival of the fittest.

8. (Optional.) Improvement of plants by man: artificial selection of favorable variations; artificial crossing of related species; some of the valuable crops of New York State; some of the methods of increasing crop production.

\section{H. Plants in their Relation to Human Welfare.}

1. Some uses of plants to man.

$a$. Uses of plants for food.

$b$. Uses of plants for flavoring extracts, beverages, and medicines.

c. Uses of plants for clothing.

2. Forests and forest conservation. ${ }^{1}$

a. Definitions.

(1) A forest means a growth of trees sufficiently dense to form a fairly unbroken canopy of trees. A forest has a population of animals and plants peculiar to itself, a soil of its own making, and a climate different from that of the open country.

(2) "Forestry is the preservation of forests by wise use." ROosEvelt.

b. Value of forests.

(1) Esthetic value - beauty of form and color of forest trees.

(2) Value in affecting drainage.

(a) By retaining water in the soil through the agency of the roots.

${ }_{1}$ The authors are indebted to Miss Kate B. Hixon, of the Morris High School, New York, N.Y., for the review topies on Forests and Forest Conservation. 
(b) By preventing too rapid evaporation from the soil, through the help of the foliage.

(c) By retarding the melting of snow, thus preventing freshets.

(3) Value in affecting climate.

(a) By bringing moisture into the air, which falls as rain.

(b) By setting oxygen free into the air in the process of starch making.

(c) By acting as a windbreak.

(4) Economic value.

(a) As a source of lumber and fuel.

(b) As a source of food (nuts, maple sugar, etc.).

(c) As a source of industrial raw materials (paper, tanning materials, wood alcohol, tar, pitch, turpentine, rosin, fibers).

c. Dangers to forests.

(1) Fires.

(2) Insects.

(3) Grazing of cattle.
(4) Careless lumbering.

(5) Fungi that cause disease.

d. Results of deforestation.

(1) Main cause of freshets, which cause destruction of property and loss of life ; they also fill up navigable streams with soil and débris.

(2) Drouth, with the consequent lessening of water power.

(3) Timber famine, especially in hard woods.

e. Methods used by the Government Bureau of Forestry to preserve forests.

(1) Allow only the cutting of dead or mature trees.

(2) Insist that each tree cut be replaced by another of the same kind.

(3) Prevent the spread of fires.

(4) Destroy insects that are injurious to trees.

(5) Restrict cattle grazing to certain seasons.

3. Fungi and their relation to human welfare.

a. Bacteria; microscopical appearance and size; reproduc- 
tion; necessary conditions for growth; relation (1) to soil fertility, (2) to flavors of food, (3) to the industries, (4) to diseases.

b. (Optional.) Yeast: microscopical appearance and size; reproduction; changes caused by yeast; uses of yeast.

c. (Optional.) Bread mold; structure; reproduction and life history ; nutrition in the fungi.

$d$. (Optional.) Other fungi : mushrooms, rusts, and smuts; economic importance.

\section{Plant Classification.}

1. Common methods of classification.

$a$. Herbs, shrubs, and trees : define each; give examples.

$b$. Annuals, biennials, and perennials; define each; give examples.

c. Deciduous and evergreen trees and shrubs: define each; give examples.

2. (Optional.) Scientific method of classification.

$a$. Seed-producing plants.

(1) Gymnospeims and angiosperms.

(2) Monocotyledons and dicotyledons.

(3) Plant family, genus, species, variety.

$b$. Spore-producing plants.

(1) Ferns: fern plant; spores; prothallus; fertilization of the egg-cells; alternation of generations.

(2) Mosses: moss plant; protonema; sexual generation; alternation of generations.

(3) Algæ: Spirogyra, its structure, methods of reproduction and functions; Pleurococcus and other algæ.

(4) Fungi (see H, 3, above).

Note. The following outlines were prepared by Miss Martha F. Goddard, late of the Morris High School, New York, N.Y. They furnish an admirable review of the most important nutritive 
and reproductive functions of plants. Pupils might either copy the whole outline into their note-books, supplying the words represented by the figures, or make a list of the words, numbering them to correspond to the figures below.

\section{Nutrition in Green Plants that Produce Seeds}

Soil-water, in which are dissolved compounds that contain nitrogen and other mineral matters needed by the plant, is absorbed by (1) which are (2) found (3) of roots. The process by which this soilwater enters is called (4). In the root-hair the membrane is the (5). More liquid enters the root-hair than passes out, because (6). The substances admitted in the soil-water are regulated by the action of the (7) in the cell, through which the liquid must pass. The cellsap passes from one cell of the root to the next, until it reaches thick-walled tubular cells called (8), which form part of the (9) of the root, stem, and leaf. The liquid passes up through these until it reaches spaces between the thin-walled leaf-cells, and finally the sap gets into these cells.

A gas called (10) is taken in through epidermis cells of the leaf, and through openings called (11) between certain cells of the epidermis that are known as (12). In the soft cells of the inside of the leaf are tiny masses of protoplasm which contain a green coloring matter called (13). These green masses of protoplasm are called (14). They can manufacture starch out of the (15) and the (16) in the presence of (17). The elements in $\mathrm{CO}_{2}$ and $\mathrm{H}_{2} \mathrm{O}$, however, are not in quite the right proportions, so (18) is given off as a waste product. The soil-water is such a weak solution of mineral matter that not all the water can be used by the plant, so this water that is not needed is given off by a process called (19). The amount of water thus given off is regulated by the action of the (20) that surround each (21).

During the night the starch is changed to (22) by a process known as (23). This liquid food then passes down through the (24) of the veins and bast or fibrous bark to places that serve for storage or to growing regions where it is used to make a substance for cellwall building known as (25). Some of the sugar is made by the pro- 
toplasm of the plant to unite with the nitrogen of the nitrates and with the sulphur and phosphorus of other mineral matters derived from the soil, and a compound is formed called (26) which the growing regions use to make into more (27). This last change is called assimilation.

Some of the proteids may also be stored for future use. Food may be stored in the (28), the (29), the (30), the (31), or in any thinwalled cells.

\section{Optional. The Life-History of a Seed-Plant}

See note, p. 193.

The mother-plant produces flowers which attract insects by their (1) or by their (2). These animals carry (3) on their hairy bodies from the (4) of one flower to the (5) of another. Here nourished by a (6) it sends out a tube which grows down through (a) the (7), $(b)$ the (8), and (c) the (9), and here enters a tiny opening called the (10) in the (11). There a nucleus of the pollen grain (called a sperm nucleus) unites with a nucleus of the egg-cell in the ovule during the process of (12) to form one cell (called a fertilized egg-cell) which now develops into a tiny plant known as the (13) of the seed. This little plant has (a) a minute stem called the (14), $(b)$ one, two, or more seed-leaves known as (15), and (c) usually a tiny bud called the (16).

The mother-plant feeds this embryo until it has grown thus far, and also stores up food for further growth. This may be put in the cotyledons as in the (17) seed, or it may be packed around the embryo, when it is called (18), as in the (19). To protect the embryo until time for germination, the seed has one or more outer coverings known as (20). That the seed may be carried away from the motherplant, and so have better opportunities for development, the mother-plant provides the fruit or the seeds $(a)$ with (21) or (22) so they may be carried by the wind, or $(b)$ with (23) so they may cling to the wool of animals, or $(c)$ with (24) so they may tempt animals to eat them; in the last case (as in the peach or cherry) the contents of the seed are protected by (25). 
When the seed has favorable surroundings, namely (26), (27), and (28), it germinates. If it has one cotyledon, the plant is called (29), the woody bundles in its stem will be (30), and the veining of the leaves will probably be (31). If two cotyledons are present in the seed, the plant is called (32), the woody bundles in its stem will be arranged (33), and the veining of the leaves will be (34).

The principal food materials stored in seeds are three in number, namely, (a) (35), which is tested by (36); (b) (37), tested by (38); and $(c)$ (39), tested by (40). Sometimes a fourth nutrient (41) is stored in other parts of the plant; its presence may be detected by (42). 


\section{APPENDIX V}

\section{LIST OF SUGGESTED BOOKS OF REFERENCE IN BIOLOGY}

\section{General Biology}

1. Cyclopedia of American Agriculture. Edited by L. H. Bailey. 4 vols. - The Macmillan Co., N. Y. City. $\$ 20$ net. Vol. I, Farms ; Vol. II, Crops ; Vol. III, Animals ; Vol. IV, The Farm and the Community. We do not hesitate to say that Vols. II and III of this series are the most valuable books of reference known to us for teachers or students in plant and animal biology. Experts on the many subjects treated have epitomized in a readable form a vast amount of information which could only be found by patient search through many volumes. If schools cannot purchase these books, teachers might well urge that they be put on the shelves of the public library, for all four volumes will be found of great value as books of general reference, especially in rural communities.

2. Nature Study and Life, by Dr. C. F. Hodge. - Ginn and Co. $\$ 1.20$. Contains many suggestions for the teaching of both plant and animal biology.

3. General Biology, by Sedgwick and Wilson. - Henry Holt and Co. \$1.75. While mainly devoted to a consideration of the earthworm and the fern (both optional topics), this book will give teachers a clear idea of the biology of a plant and of an animal, and of the composition and characteristics of protoplasm. It also contains an admirable account of yeast, bacteria, Amœba and Paramecium. 
4. Teaching of Biology, by Lloyd and Bigelow. - Longmans, Green and Co. \$1.50. Deals largely with methods of teaching nature study, botany, zoölogy, and human physiology.

\section{Plant Biology}

5. Practical Botany, by Bergen and Caldwell. - Ginn and Co. $\$ 1.30$.

6. College Botany, by G. F. Atkinson. - Henry Holt and Co. $\$ 1.50$.

7. Readers in Botany, by Jane C. Newell. - Ginn and Co. 2 vols. $\$ .60$ each.

8. How to know the Wild Flowers, by Mrs. William Starr Dana. - The Macmillan Co. \$1.50.

9. How to know the Fruits, by Maude G. Peterson. - The Macmillan Co. $\$ 1.50$.

10. Tree Book, by Julia E. Rogers. - Doubleday, Page and Co. $\$ 4$.

11. New Creations in Plant Life, by W. S. Harwood. - The Macmillan Co. \$1.75.

12. Bacteria, Yeasts, and Moulds in the Home, by H. W. Conn. Ginn and Co. \$1.

13. Farmers' Bulletins, which can be obtained free by applying to the U. S. Dept. of Agriculture, Washington, D.C. The various Bulletins contain many important facts relating to both animals and plants.

\section{Animal Biology}

14. Animal Life, by Jordan and Kellogg. - Appleton. \$1.20.

15. General Zoölogy, by Linville and Kelly. - Ginn and Co. $\$ 1.50$.

16. American Natural History (vertebrates only), by W. T. Hornaday. $\$ 3.50$.

17. Insect Book, by L. O. Howard. - Doubleday, Page and Co. $\$ 3$. 
18. Manual of Insects, by Comstock. - Comstock Publishing Co., Ithaca, N.Y. $\$ 3.75$.

19. Economic Entomology, by J. B. Smith. Lippincott. $\$ 2.50$.

20. Birds of North-Eastern United States, by Frank Chapman. Appleton. \$3.

21. Bird Life (with colored plates), by Frank Chapman. - Appleton. $\$ 2$.

22. Relation of Birds to Man, by Weed and Dearborn. Lippincott. $\$ 2.50$.

23. Food and Game Fishes, by Jordan and Everman. - Doubleday,

Page and Co. \$4.

24. Farmers' Bulletins (see 13 above).

25. Story of the Fishes, by J. N. Baskett. - Appleton. \$.65.

\section{Human Biology}

26. The Human Mechanism, by Hough and Sedgwick. - Ginn and Co. $\$ 2.50$.

27. General Physiology, by W. H. Howell. W. B. Saunders. $\$ 4$.

28. Studies in Physiology, by James E. Peabody. - The Macmillan Co. $\$ 1.10$.

29. Laboratory Exereises in Anatomy and Physiology, by James E. Peabody. Henry Holt and Co. \$.60.

30. Infection and Immunity, by George M. Sternberg. - Putnams. $\$ 1.75$.

31. Pathogenic Micro-organisms, by W. H. Park. - Lea Brothers and Co. $\$ 3.75$.

32. Walter Reed and Yellow Fever, by H. A. Kelly. - McClure, Phillips and Co. $\$ 1.50$.

33. The Malaria Mosquito, by B. E. Dahlgren. - American Museum of Natural History. \$.15. 



\section{INDEX}

Aërial roots, 102.

Ailanthus fruit, 92.

Air, need of, for growth, 67. relation of, to soil, 111.

Air roots, 102.

Air spaces, 60, 62, Fig. 22.

Alcohol, formed by yeast, 147 .

Algæ, 166-169.

Alternate arrangement, 52.

Alternation of generations, in fern, 163.

in moss, 166.

Angiosperms, 159, 170.

Annual, an, 156.

Annual rings, 47, 51, Fig. 17.

Annual scars, 55.

Anther, 71, 73, 81, 88, Fig. 25.

Antheridia, of fern, 162, Fig. 83, $D$. of moss, 164.

Apparatus, price-list of, 173-175.

Apple, fruit, Figs. 37, 38. leaves, Fig. 19.

Archegonia of fern, 163, Fig. 83, $F$. of moss, 164, Fig. 84.

Artificial crossing of related species, 120.

Artificial selection, 119:

Asexual generation, of fern, 163. of moss, 166.

Asparagus, 127.

Assimilation, 31 .

Bacillus form of bacteria, Fig. 71, $B, C, D$.

Bacteria, 140-145, Fig. 71.

Bamboo, 49, Fig. 18.

Bark, 45.

Bast, 46.

Bean fruit, 89.

Bean seed, 97-100.

Bee, Figs. 30, 31
Beggar's ticks, 93.

Benzine as used in testing for fat, 20 .

Beverages, 128-130.

Bidens, 93.

Biennial, 158.

Biology, definition of, 4 .

Blade of leaf, 55 .

Body, cell-, 28, 29.

Books, list suggested for reference, 197-199.

Botany, definition of, 4.

Bread-making, 148.

Bread mold, 149-151.

Breathing in plants and animals, 69 .

Budding of yeast, 146, Fig. 74 .

Buds, 53.

of yeast, 146 .

Bud-scales, 53.

Bud-scale scars, 55 .

Bulbs, 108.

Bumblebees, 81.

Burbank, Luther, 122.

Burdock, 93.

Burs, 93.

Cabbage, 127.

Calyx, 71, 79, 88.

Cambium, 46, 51, 63.

Camphor, 129.

Capsule of moss, 164.

Carbohydrates, meaning of, 13, 14 . composition, 13, 14.

manufacture of, 24, 60, 69 .

Carbon, 6.

Carbon dioxid, $7,8$.

in air, 11.

necessary for starch manufacture, 23.

formed in growing plants, 68 .

formed by yeast, 147 .

Castor bean seedling, Fig. 44. 
Cauliflower, 127.

Cell-body, 28, 29.

Cell division, 30.

Cell-nucleus, 28, 29.

Cell-sap, 30.

Cells of plants, 27, 29, Figs. 6,7 . definition, 30 . osmosis in, 34 .

Cellulose, 29.

Cell-wall, 28, 29.

Central cylinder of roots, 39.

Charts, price-list of, 175-176.

Chemicals, price-list of, 176-177.

Cherries, 96.

Chestnut, fruits, Fig. 39. leaf, Fig. 20, $B$.

Chlorophyll, 23, 28, 51, 60, 62, Fig. 22.

Chlorophyll bands, 167, Fig. 85 .

Chocolate, 129, Fig. 63.

Cideri, 148.

Cilia, 140, Fig. 71.

Cinchona, 129.

Citranges, 122.

Classification of plants, 154-170.

Clay, 110.

Coal, 133.

Coal period, forests of, Fig. 65 .

Coccus form of bacteria, Fig. 71, $A$.

Cocklebur, 93.

Cocoa, 129, Fig. 63.

Coffee, 129, Fig. 61.

Colony of bacteria, 142, Fig. 71, $A$.

Compound, definition of, 12 .

Compound leaf, 56.

Conditions essential for plant growth, 108-114.

Conjugation in spirogyra, 168 .

Conservation of forests, 138.

Consumption, due to bacteria, 145 .

Corn, cross-pollination, 85.

Corn grain, 95, 128.

Corn grains, 101. nutrients stored in, 104. use of endosperm of, 104.

Corn production in U. S., 119.

Corn seedling, 100.

Corn stalk, 47, 49, 50 .

Corn "tassels," 87, Fig. 33.
Corn ears, 88. silk, 88.

Corolla, 71, 79, 88.

Cortex of roots, 39 .

Cotton, 130-132.

Cotyledon, 98, 101.

Crops, valuable, of N. Y. State, 122, Fig. 58.

Crossing, artificial, of related species, 120.

Cross-pollination, 79.

by bumblebees, 81 .

in pansy, $82-84$.

by insects, 86 .

by wind, 87 .

Cucumber fruit, 90.

Cultivation of soil, 113.

Dairy products of N. Y. State, 123.

Dandelion plant, Fig. 55.

Dangers to forests, 137 .

Darwin, Charles, 82, 118, Fig. 54.

Deciduous trees and shrubs, 158.

Decomposition, result of action of bacteria, 140 .

Diastase, 36.

Dicotyledons, 160, 170.

Digestion, definition of, 37 . of starch, 37 .

Digestive ferments, 38 .

Diphtheria, due to bacteria, 145 .

Directions for note-books, 185-186.

Disease-producing bacteria, 145 .

Dispersal of seeds, 91 .

Distillation, 147.

Distilled liquors, 148.

Division of cell, 30 .

Drainage, 111, 114.

Drawings, in laboratory, 181, Figs. 90,91 .

Drugs, 130.

Dry fruits, 96 .

Ducts, 45, 50, 62, Fig. 14.

Egg-cell, 77.

Element, definition of, 12.

Elm fruit, 92.

Elodea, 25, 28, Fig. 5.

Embryo, 77, 98, Fig. 29. 
Endosperm, 101. use of, 104.

Energy, definition, 64 . transformations of, 65 . liberation of, 66, 67 . source of, 66.

Epidermis, of root, 44, 62. of stem, 51,62 . of leaf, 56, 61, 62, Figs. 21, 22.

Equipment of laboratory, 171-177.

Erosion, as result of destruction of forests, 137.

Essential organs, 71, 73.

Evergreen trees and shrubs, 158 .

Excretion of water, 61 .

Existence, struggle for, 114-119, Fig. 53.

Family, plant, 160, 170.

Fat, composition of, 14, 15 . test for, 19.

Fehling's solution, preparation of, 17 .

Fermentation, 148.

Ferments, digestive, 38 .

Ferns, 161-164, Figs. 82, 83.

Fertilization, 76, 77, 88. of egg-cell in fern, 163.

Fertilized egg-cell, 77.

Fertilizers, 114.

Fiber-producing plants, 130-132.

Fibers, 47.

Fibrous bark, 46 .

Filament, 71, 73, 88, Fig. 25.

Fippin, E. O., 123.

Fire, lanes, 139. wardens, 139 .

Flavoring extracts, 128.

Flavors of food, 145.

Flax, 130.

Fleshy fruits, 93, 96.

Floods, prevention of, 136.

Floral envelopes, 71, 72, 79, 88.

Flowers, 70-88. tulip, 70-72.

gladiolus, 72-74.

pansy 79-82.

Food substances, list of 13 .

manufacture by plants, 22,60 . transfer of, 50 .
Food substances, storage of, 61 . in corn grains, 104.

Forest conservation, 138.

Forest fires, 134, 137, 139.

Forests, dangers to, 137.

Fronds of ferns, 161.

Frosts, loss of crops due to, 117.

Fruit, definition of, 94 .

hybrid, 122.

stalk, 91, 92.

Fruits, 89-96.

Fuel, 133.

Functions of organs, 27.

Fungi, relation to human welfare, 139-153.

Fungous diseases, loss of crops due to, 117.

Garden, tumbler, 102. glass-plate, 102.

Generations, alternation of, in fern, 163.

Generative nucleus, 77.

Genus, plant, 160, 170.

Germination of pollen grains, 76 .

Cladiolus, 72-74.

Glass-plate garden, 102.

Goddard, Miss Martha F., 193.

Grafting, 105-106.

Grapes, 129.

Grape sugar, composition of, 14, 15. test for, 16. osmosis of, 33.

Gravel, 110.

Grazing animals, a danger to young trees, 137.

Growth of crystals, 2 (footnote).

Growth of living things, 2,30 .

Growth of plants, five essential conditions for, 108.

Guard-cells of stoma, 58, 61, 62, Fig. 21.

Gymnosperms, 159, 170.

Harrow, 114, Fig. 51.

Hay crop of N. Y. State, 122.

Heat, energy, 64. relation of, to soil, 112 .

Hemp, 130, 145. 
Herb, 156, Fig. 80.

High school education, value of, 124 . Hilum, 97.

Hixon, Miss Kate B., 191 (footnote). Horse-chestnut, stem, 45, 52. leaves, Fig. 20, $K$.

Human welfare, relation of plants to, 126-153.

Humus, 111.

Hybrid fruits, 122.

Hydrogen, 9.

Hyphæ of molds, 150.

Hypocotyl, 98.

Improvement of plants by man, 119125, Figs. 57, 59.

Indigo, preparation of, 145.

Insects, a danger to forests, 137. loss of crops due to, 117 .

Iodine solution, preparation, 15 .

Irrigation, 111.

Jute, 145.

Kerosene, 133.

King, Dr. C. A., 102 (footnote).

Kupfer, Miss Elsie M. (footnote), 27.

Laboratory equipment, 171-177. table, 171.

Lateral buds, 53 .

Layer, 106.

Leaflets, 56.

Leaf scars, 53.

Leaf-stalk, 55.

Leaves, arrangement of, 52 . structure of, 55 .

Lenticels, $51,55,62$.

Lettuce, 127.

Life-history of a seed-plant, 195.

Lifeless things, characteristics of, 1.

Lilac leaf, Fig. 20, $A$.

Lime water, preparation of, 5 .

Linden fruit, 91.

Linen, preparation of, 145.

Living things, characteristics of, 1 .

Lumber, 133.

Lumbering, wrong method of, Fig. 67. right method of, Fig. 68.
Malt, 148.

Mann, Paul B., 66 (footnote).

Maple, fruit, 91. sugar, 136.

Medicines, 129-130.

Medullary rays, 47, 50, Fig. 17.

Mesophyll, 57, 60.

Micropyle, 76, 98, Fig. 29.

Milkweed fruit and seeds, 92, Fig. 36.

Mineral matter, test for, 20.

Mixture, definition of, 12.

Moisture, relation to germination and growth, 108-109.

Mold, bread, 149-151, Fig. 75. vegetable, 111.

Monocotyledons, 159, 160, 170.

Mosses, 164-166, Fig. 84. moss plant, 164 . protonema, 164.

Mushrooms, 151, Fig. 76.

Nectar, 80.

Nitric acid, test for protein, 18.

Nitrogen, 11.

Note-books in biology, 181-187.

Nucleus, 28, 29.

Nutrition, in fungi, 150.

in green plants that produce seeds, 194.

Nutritive hyphæ, 150.

organs of plants, 39 .

Oak, wood, 46.

leaves, Fig. 20, $C, G$.

tree, amount of evaporation from 136.

Opium, 129.

Opposite arrangement, 52.

Orange crop, 120-122.

Order of topics, 178-180.

Organs, of a plant, 27. nutritive, 39.

Osmosis, 32-38. water, 33 . of grape sugar, 33 . in living cells, 34 . of starch, 35 . definition and applications, 35 . protein, 37. 
Osmosis, in root-hairs, 44 .

Ovary, $72,73,81,88$.

Ovules, 72, 74 .

Oxidation, definition of, 13.

liberation of energy by, 66 .

relation of oxygen and carbon dioxid to, 67 .

Oxygen, 6.

given off by green plants in sunlight, 25.

supply of, for animals, 25 .

necessity of, for growth, 67 .

Palmately compound, 56 .

Pansy, 79-82.

Darwin's experiments with, 82-84.

Parsnips, 127, 156.

Peaches, 96, 128.

Pea, flower, Fig. 35.

fruit, 89, Figs. 35, 43.

Peppermint, 129.

Perennials, 158.

Petals, 71, 79, 88.

Pinnately compound, 56.

Pistil, 71, 73, 81, 88, Figs. 24, 28.

Pistillate flowers, 87, Figs. $32, B, 34$.

Pith, 46, 47, 63.

Pith rays, 47, 63.

Placenta, 89.

Plant, family, 160, 170.

genus, 160, 170.

species, 161, 170.

variety, 161,170 .

Plants, parts of, 26-31.

organs and functions, 27.

microscopic structure, 27.

cells, 27.

nutritive organs, 39.

Pleurococcus, 169, Fig. 86.

Plow, 113, Fig. 50.

Plumule, 98.

Pollen, 71, 73, Fig. 26.

Pollen tubes, 75, Figs. 26, 27.

Pollination, 74, 76, 88.

Pond scum, 166.

Poppy, 129.

Potato crop of N. Y. State, 122.

Potatoes, 107, 127, Fig. 49.

Preparations for laboratory, 175.
Prevention of self-pollination, 84-85.

Primary root, 100.

Protection of forests, 138-139.

Protein, use of term, 13 (footnote). composition of, 14, 15.

test for, 18.

manufacture of, 24, 61 .

osmosis, 37.

Prothallus of fern, 162, Fig. 83.

Protonema of moss, 164.

Protoplasm, 30.

Prudden, Dr. T. M., 142.

Pumpkin, cross-pollination, 85.

Quartered oak, 47.

Quinine, 129.

Radiometer, 66 (footnote).

Rainfall, regulation of, 136 .

Raspberry fruits, Fig. 40.

Reference books, list of, suggested, 197-199.

Reforesting, 138.

Repair of living things, 2.

Reproduction, of living things, 3 . in plants, 70-96.

Reproductive hyphæ of molds, 150.

Respiration, definition, 68, 69.

Review topics in plant biology, 188196.

Rhizoids of ferns, 163, Fig. 83, ${ }^{C} C$.

Rhizome of fern, 162, Fig. 82.

Rind, 47.

Root-hairs, 40, Figs. 11, 12, 13. osmosis in, 44.

Roots, structure of, 39-41. functions of, 41-43.

primary, 100.

secondary, 100.

aërial, 102.

Root-tip, 40.

Root-tubercles, 144, Fig. 72.

bacteria in, Fig. 73.

Rotation of crops, 124.

Runner, 106.

Rusts, 152.

Sand, 110.

Sap, of cell, 30 . 
Sap, path through roots, 42,43 . path through stem, $48,49$. path through leaves, 59 .

Schleiden and Schwann, 29.

Science and its subdivisions, 3.

Scion, 105.

Sea weeds, 169.

Secondary root, 100.

Seed-coat, 98.

Seed-dispersal, 91-94.

Seed-leaves, 98.

Seedlings, comparison of, 103-104.

Seed-producing plants, 159-161.

Seeds, 72, 74, 77, 97-105. numbers, produced by plants, 115 .

Selection, artificial, 119.

Self-pollination, 79 . prevention of, 84-86.

Sepals, 71, 79, 88 .

Sexual generation, in fern, 163. in moss; $164,166$.

Sheath leaf, 100.

Shrub, 156, Fig. 79.

Sieve tubes, 50, 62, Fig. 16.

Slip, 106.

Smuts, 152-153, Fig. 77.

Soil, 110-114.

moisture of 111.

air in, 111.

heat, relation of soil to, 112 . cultivation of, 113.

Soil water, absorption of, 41. transmission of, $42,48,58$.

Sorus of fern, 162, Fig. 82.

Source of energy, 66.

Species, plant, 161, 170.

Spermaries of fern, 163.

Sperm-cells of fern, 163.

Sperm nucleus, 77, Figs. 27, 28, 29.

Spirillum form of bacteria, Fig. 71, $D$.

Spirogyra, 167, Fig. 85.

Spore-cases, of mold, 150. of ferns, 162, Figs. 82, 83.

Spore formation in bacteria, 143, Fig. $71, D$.

Spore-producing plants, 161-170.

Spores, of mold, 150. of ferns, 162, Figs. 82, 83.

Spur, 80 .
Squash, cross-pollination, 86, Fig. 32 .

Squash, seedling, Fig. 45.

Stamens, 71, 72, 80, 88, Fig. 24.

Staminate flowers, 87, Figs. 32, A, 33.

Starch, composition of, 13, 15 .

test for, 15 .

manufacture in sunlight, 22 .

manufacture by different kinds of leaves, 22 (footnote).

manufacture by chlorophyll, 23 .

digestion of, 36,37 .

Stems, structure, 45-48.

functions of, 48-51.

changes during growth, 51 .

Stickers, 93.

Stigma, 72, 73, 81, 88, Fig. 25.

Stipules, 56.

Stock, 105.

Stoma, 58, 60, 61, 62, Figs. 21, 22.

Stone fruits, 96 .

Storage of foods, 61 .

Story of bacteria, 142 (footnote).

Strawberry, flower, Fig. 41. fruit, Fig. 42. plant, Fig. 48.

Struggle for existence among plants, 114-119, Fig. 53.

Style, 73, 81, 88.

Sugar cane, 127.

Sun, as source of energy, 66.

Sunlight, necessary for starch manufacture, 22.

Survival of the fittest, 118-119, Figs. 53,55 .

Sweet potato, 127, Fig. 60.

Tea, 129, Fig. 62 .

Temperature, of soil, 112. relation of, to germination and growth, 109.

Terminal bud, 53 .

Toadstools, 151.

Tokay grape fruit, 90.

Tomato fruit, 90 .

Topics, order of, 178-180.

Transfer of food materials, 50, 62 .

Transformations of energy, 65 .

Tree, 154, Figs. 78, 79.

Tubers, 107. 
Tufted fruits or seeds, 92 .

Tulip, flower, 70-72.

Tumbler garden, 102.

Typhoid fever due to bacteria, 145 .

Uses of plants, 127-132.

of forests, 132-137.

Variation among plants, 114, Fig. 52. Variety, plant, 161, 170.

Vegetable crop of N. Y. State, 122.

Vegetable mold, 111.

Veins of leaf, 55 .

Vinegar, preparation of, 145.

Wall, of cell, 28, 29. of ovary, 72,73 .

Water, composition and preparation, 10. test for, 20 .
Water, osmosis of, 33 . given off from leaves, 59 .

Webber, Dr. H. J., 120-122.

Wheat, 128. seedling, Fig. 46.

Window box, 102.

Wine, 129, 148.

Winged fruits, 91.

Wood, 46.

Wood-cells, 43, 49, 63 .

Woody bundles, 47, 50, Fig. 15.

Yeast, 146-149, Fig. 74. reproduction of, 146 . buds, 146. changes caused by, 147 . uses of, 148.

Zoölogy, definition, 4.

Zygospores of spirogyra, 168. 

$T^{H E}$ following pages contain advertisements of a few of the Macmillan books on kindred subjects 



\section{Animal and Human Biology}

BY JAMES EDWARD PEABODY

Head of the Department of Biology, Morris High School, Bronx, New York City AND

\section{ARTHUR ELLSWORTH HUNT}

Head of the Department of Biology, Manual Training High School, Brooklyn, New York

This book, which follows Plant Biology by the same authors, is part of a one year course in Elementary Biology intended for use in secondary schools. An experience of more than fifteen years is the basis for the book and practically all of the laboratory outlines have been tried out in mimeograph form in classes in New York City high schools under the supervision of the present authors. These exercises have been revised and adjusted until they exactly meet the needs of such classes.

A list of the chapter titles follows:

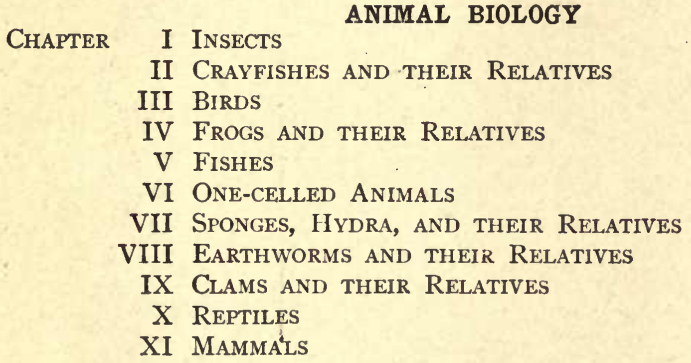

\section{HUMAN BIOLOGY}

Chapter I General Structure of the Human Body

II Microörganisms and their Relation to Human Welfare

III FOODS AND THEIR USES

IV Stimulants, Narcotics, and Poisons

$\mathrm{V}$ Digestion OF THE NUTRIENTS

Vi Circulation of the Nutrients

VII Respiration and the Production of Energy

VIII AdDitional Toyics in Hygiene

IX WORK OF GREAT BIOLOGISTS

\section{THE MACMILLAN COMPANY}

Publishers 


\section{CHEMISTRY}

\section{By WILliAM CONGER MORGAN, Ph.D. (Yale)}

Assistant Professor of Chemistry in the University of California

AND

JAMES A. LYMAN, Ph.D. (Johns Hopkins)

Professor of Chemistry in Pomona College

Cloth I2mo 429 pages $\$ 1.25$ net

The characteristic feature of this new book on chemistry is the success with which the facts of every-day life have been utilized and made an essential part of chemical science. The treatment and arrangement of material are sane, scientific, and up to date.

"The book endeavors to encourage the student to think inductively. His attention is first directed to certain experimental facts ; the general experience of the race along similar lines is then called to mind and the formulation of the law is the last point in the development. To use the deductive method in the presentation of scientific truths which have been derived inductively, is to fail to present the correct idea of the scientific method, a proper appreciation of which will be of as great value as anything that may be derived from the study of science."

\section{TEACHERS PRAISE THE BOOK}

D. N. Crosthwait, A.M., Teacher of Chemistry, Lincoln High School, Kansas City, Missouri.

"Morgan and Lyman have succeeded in writing a very delightful and teachable chemistry. The beauty of it is, it seems vitally to articulate with the great industries of our times."

\section{THE MACMILLAN COMPANY Publishers




\section{Introduction to General Science}

\section{By PERCY E. ROWELL, B.Sc.}

\section{Cloth I2mo 302 pages $\$ .75$ net}

The increasing demand for a thorough, comprehensible, and practical text-book on the subject is met by Rowell's "Introduction to General Science," the distinctive features of which are :

I. The book gives a broad, adequate view of the general field of science. The elements of physics and chemistry receive particular emphasis, but biology, physiography, and several phases of applied science are duly considered.

2. Despite the necessity for treating various sciences, the book is remarkable for its continuity of thought. The interrelation of scientific facts is constantly and clearly pointed out.

3. The treatment is clear-cut, brisk, and thorough, the material well chosen and up to date, while the general workmanship of the book renders it attractive and serviceable.

4. There are over 90 laboratory exercises in the book, a number of them entirely new, and all of them illustrative of the text.

5. Reference reading is encouraged, and lists of carefully selected standard reference books are suggested. Those teachers, however, who do not care to take up detailed work of this sort may give a satisfactory course by using in connection with the book United States Government bulletins alone, to which definite reference is made in the lists of reference readings throughout the book.

\section{TEACHERS}

call the book "thorough," "practical," "comprehensive," "clear," "satisfactory," "a great aid to the science teacher."

Mr. N. P. Lawson of Taunton, Washington, writes:

"I have examined Rowell's 'Introduction to General Science' quite carefully. It wears. The more I use it the better I like it. There is room left for the teacher. He doesn't have to crowd himself in. This book can hardly fail to innoculate any one with the bulletin habit, in which I am a firm believer. In its encouragement of wide reading and first-hand acquaintance with books through the excellent references given, this compact little volume is an education in itself. If I were with your company I should wish to push this book. I believe in it."

\section{THE MACMILLAN COMPANY}




\title{
Elements of Physics
}

\author{
BY HENRY CREW \\ Professor of Physics, Northwestern University \\ REVISED BY \\ FRANKLIN T. JONES
}

Teacher of Physics, University School, Cleveland, Ohio

Cloth I2mo xiv +435 pages \$r.ro

It is the aim of this book to furnish in teachable form material for a fundamental course in Physics which shall be within the comprehension of the pupil in the secondary school. The authors design to show that Physics is the science of everyday life and that it is a logical and orderly study.

The problems and exercises in this text are unique. Instead of the old-fashioned, nerve-racking problem based on impossible and impractical contingencies, the exercises in the new Crew and Jones are first of all sensible. They are designed to be practical illustrations of the actual working. out of the principles of Physics and to be altogether within the bounds of the mathematical information with which the average high school pupil finds himself equipped. The diagrams and illustrations in the text are clear and helpful. They add much to the attractiveness and to the effectiveness of the subject matter. The formulæ are derived in as simple a way as is consistent with scientific accuracy. Long mathematical derivations, always incomprehensible to the young student and therefore an unnecessary aggravation to him, are avoided. The treatment of the text will be found throughout up to date, interesting, and sound.

\section{Laboratory Problems in Physics}

\section{By FRANKLIN T. JONES}

Teacher of Physics, University School, Cleveland

AND

ROBERT R. TATNALL, Ph.D.

Instructor in Physics in Northwestern University, formerly Instructor in Physics in the Academy of the Northwestern University

Cloth I2mo ix +81 pages $\$ .50$

The student's Manual built to accompany the new Crew and Jones "Elements of Physics" is a complete laboratory manual adapted to the use of secondary schools. It has been the object of the authors to reduce to a minimum the expenditure of teaching energy. The apparatus suggested for use in the laboratory is simple, inexpensive, easily obtained, and easily duplicated. The book is supremely practical.

\section{THE MACMILLAN COMPANY}

\section{Publishers 64-66 Fifth Avenue New York}




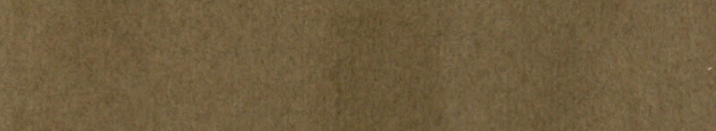

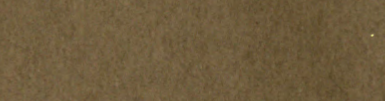

What

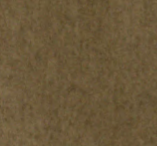

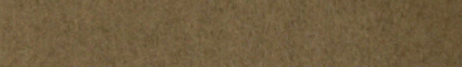

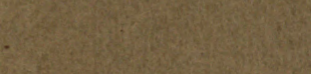

Sistive

(1)

20.5.

40

(1)

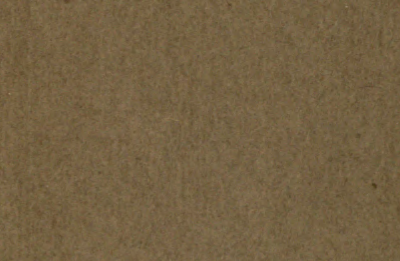

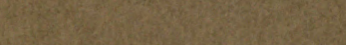

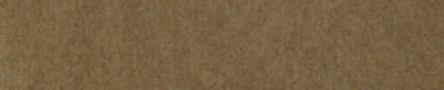

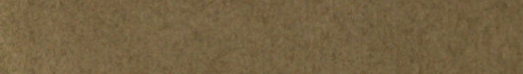

$\log ^{2}+2 x+4$

(1)

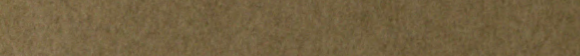

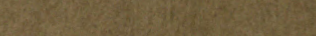

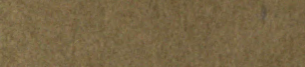

(2) 


\section{DAY USE}

RETURN TO DESK FROM WHICH BORROWED

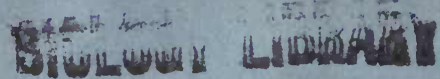

This book is due on the last date stamped below, or on the date to which renewed.

Renewed books are subject to immediate recall.

MAR 151965

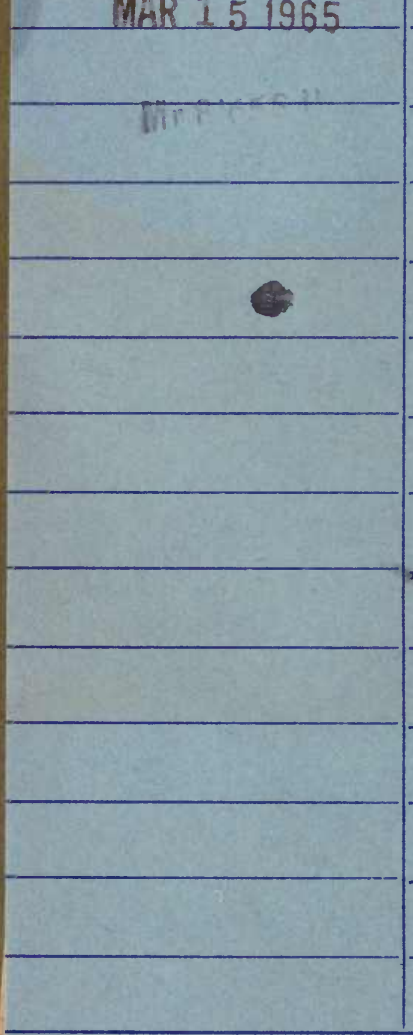

I.D 21-40m-4,'64

(E4555s10) 476

General Library

University of California

Berkeley 


\section{U.C. BERKELEY LIBRARIES U.C. BERKELEY LBRAR CO26262840}

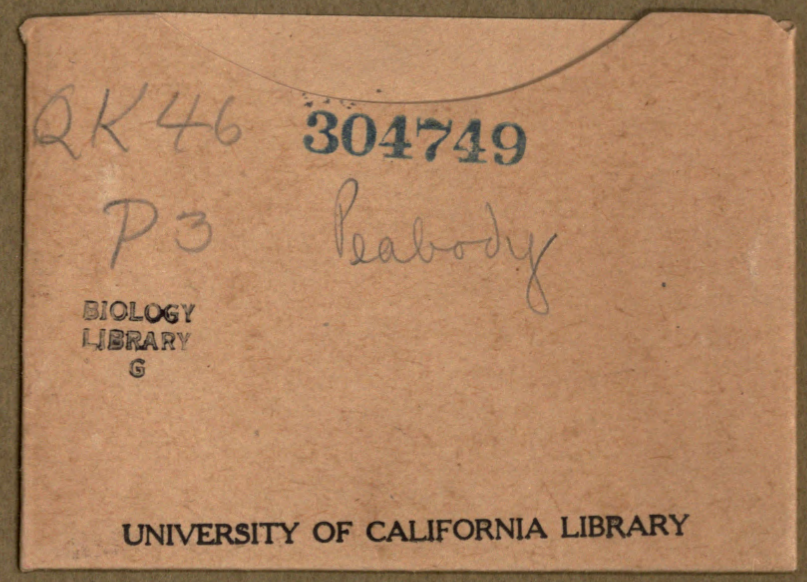


